\title{
RESULTS OF THE 2011 UIS PILOT DATA COLLECTION OF INNOVATION STATISTICS
}

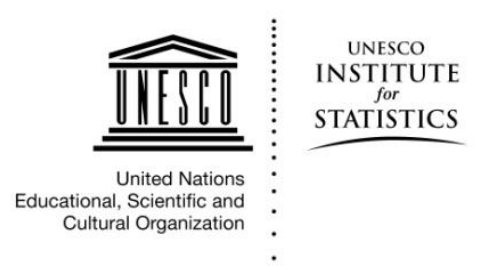




\section{UNESCO}

The constitution of the United Nations Educational, Scientific and Cultural Organization (UNESCO) was adopted by 20 countries at the London Conference in November 1945 and entered into effect on 4 November 1946. The Organization currently has 195 Member States and 8 Associate Members.

The main objective of UNESCO is to contribute to peace and security in the world by promoting collaboration among nations through education, science, culture and communication in order to foster universal respect for justice, the rule of law, and the human rights and fundamental freedoms that are affirmed for the peoples of the world, without distinction of race, sex, language or religion, by the Charter of the United Nations.

To fulfil its mandate, UNESCO performs five principal functions: 1) prospective studies on education, science, culture and communication for tomorrow's world; 2) the advancement, transfer and sharing of knowledge through research, training and teaching activities; 3) standard-setting actions for the preparation and adoption of internal instruments and statutory recommendations; 4) expertise through technical cooperation to Member States for their development policies and projects; and 5) the exchange of specialized information.

UNESCO is headquartered in Paris, France.

\section{UNESCO Institute for Statistics}

The UNESCO Institute for Statistics (UIS) is the statistical office of UNESCO and is the UN depository for global statistics in the fields of education, science and technology, culture and communication.

The UIS was established in 1999. It was created to improve UNESCO's statistical programme and to develop and deliver the timely, accurate and policy-relevant statistics needed in today's increasingly complex and rapidly changing social, political and economic environments.

The UIS is based in Montreal, Canada.

Published in 2012 by:

UNESCO Institute for Statistics

P.O. Box 6128, Succursale Centre-Ville

Montreal, Quebec H3C 3J7

Canada

Tel: $\quad$ (1514) 343-6880

Fax: $\quad(1514) 343-5740$

Email: uis.publications@unesco.org

http://www.uis.unesco.org

ISBN 978-92-9189-114-6

Ref: UIS/TD/12-04

CUNESCO-UIS 2012

The authors are responsible for the choice and presentation of the facts contained in this book and for the opinions expressed therein which are not necessarily those of UNESCO and do not commit the Organization. 


\section{Acknowledgements}

The 2011 Pilot Data Collection of Innovation Statistics by the UNESCO Institute for Statistics (UIS) marked a major step towards the development of a global data collection to be launched in 2013. The Institute would like to express its gratitude to the national experts who completed the pilot questionnaire, specifically:

$\begin{array}{ll}\text { Brazil: } & \text { Fernanda Vilhena, Alessandro Pinheiro (IBGE) } \\ \text { China: } & \text { Changlin Gao (CASTED, MOST) } \\ \text { Colombia: } & \text { Diana Lucio (OCyT) } \\ \text { Egypt: } & \text { Maged Mostafa El Sherbiny, Nora Adil (MSR) } \\ \text { Ghana: } & \text { Emmanuel Tetteh, Roland Asare (CSIR-STEPRI) } \\ \text { Indonesia: } & \text { Husein Akil, Nani Grace Berliana Sinamora (PAPPIPTEK-LIPI) } \\ \text { Israel: } & \text { Evyatar Kirschberg (CBS) } \\ \text { Malaysia: } & \text { Anita Bahari, Sabrina Kamin (MASTIC-MOST) } \\ \text { Philippines: } & \text { Berni Justimbaste, Therese Estella (STRAED-DOST) } \\ \text { Russian Federation: } & \text { Leonid Gokhberg, Vitaliy Roud, Galina Gracheva (NRU-HSE) } \\ \text { South Africa: } & \text { William Blankley, Moses Sithole, Cheryl Moses, Hlamulo } \\ & \text { Makelane, Nolitha Nkobole (DST-CeSTII, HSRC) } \\ \text { Uruguay: } & \text { Belén Baptista, Ximena Usher (ANII). }\end{array}$

The UIS is also grateful for the support of the Network for Science and Technology Indicators-Ibero-American and Inter-American (RICYT) and would like to specifically thank Guillermo Anlló and Jesica de Angelis for their help in implementing the pilot data collection in Latin America and the Caribbean.

In addition, the following experts provided valuable contributions to the design of the pilot data collection:

Adam Holbrook (CPROST)

Almamy Konte (Ministère de l'Enseignement Supérieur, des Universités et des Centres Universitaires Régionaux et de la Recherche Scientifique, Senegal)

Anthony Arundel (AIRC-UTAS and UNU-MERIT)

David Jacobson (DCU Business School)

Dudi Hidayat (PAPPIPTEK-LIPI)

Frances Anderson (Statistics Canada)

Hugo Hollanders (UNU-MERIT)

Lukovi Seke (AU-NEPAD)

Veijo Ritola (Eurostat)

Vladimir Lopez-Bassols (OECD). 


\section{Table of contents}

\section{Page}

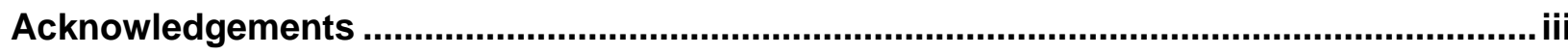

1. The 2011 UIS pilot data collection on innovation statistics .......................................... 7

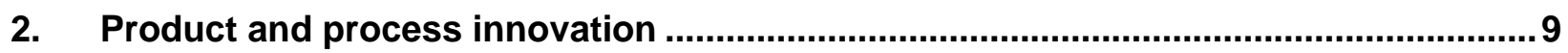

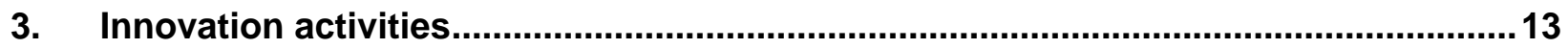

4. Sources of information ............................................................................................ 16

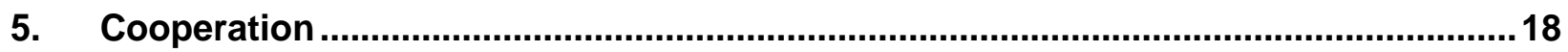

6. Factors hampering innovation activities ..............................................................21

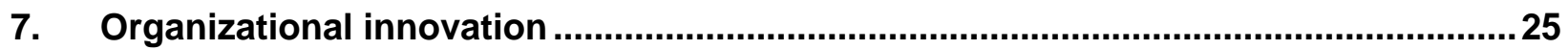

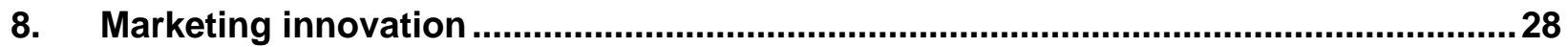

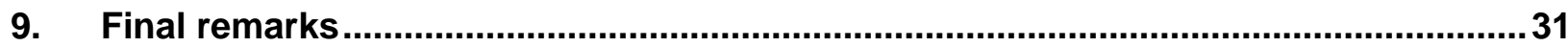

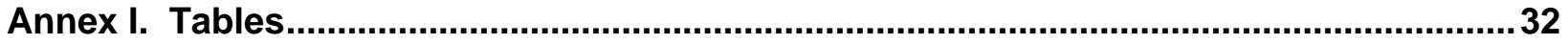

Table A1. Manufacturing firms that implement product innovation, process innovation

and product or process innovation as a percentage of all manufacturing firms ................... 32

Table A2. Manufacturing firms that implement product innovation by size class

as a percentage of manufacturing firms in each size class ............................................. 33

Table A3. Manufacturing firms that implement process innovation by size class as a percentage of manufacturing firms in each size class ............................................... 34

Table A4. Manufacturing firms that implement product or process innovation by size class as a percentage of manufacturing firms in each size class....

Table A5. Manufacturing firms that implement product innovation by economic activity (ISIC Rev. 3.1 division level) as a percentage of manufacturing firms in each economic activity.....

Table A6. Manufacturing firms that implement process innovation by economic activity (ISIC Rev. 3.1 division level) as a percentage of manufacturing firms in each economic activity

Table A7. Manufacturing firms that implement product or process innovation by economic activity (ISIC Rev. 3.1 division level) as a percentage of manufacturing firms in each economic activity.

Table A8. Other highly important hampering factors for firms as a percentage of innovation-active manufacturing firms ....

Table A9.

Highly important cost and economic hampering factors for firms as a percentage of non-innovative manufacturing firms

Table A10. Highly important knowledge hampering factors for firms as a percentage of non-innovative manufacturing firms

Table A11. Highly important market hampering factors for firms as a percentage of non-innovative manufacturing firms....

Table A12.

Other highly important hampering factors for firms as a percentage of non-innovative manufacturing firms

Table A13. Manufacturing firms that implement organizational innovation as a percentage of all manufacturing firms 
Table A14. Manufacturing firms that implement organizational innovation by size class as a percentage of manufacturing firms in each size class

Table A15. Manufacturing firms that implement marketing innovation as a percentage of all manufacturing firms

Table A16. Manufacturing firms that implement marketing innovation by size class as a percentage of manufacturing firms in each size class

Table A17. Manufacturing firms that implement any type of innovation as a percentage of all manufacturing firms

Table A18. Manufacturing firms that implement any type of innovation by size class as a percentage of manufacturing firms in each size class

Annex II. Basic methodology

Table A19. Basic methodology of the national innovation surveys

Annex III. Country profiles

\section{List of figures}

Figure 1. Manufacturing firms that implement product and process innovation as a percentage of all manufacturing firms....

Figure 2. Manufacturing firms that implement product or process innovation as a percentage of all manufacturing firms

Figure 3. Manufacturing firms that implement product or process innovation

Figure 4. Fy size class as a percentage of manufacturing firms in each size class..

manufacturing firms.

Figure 5. Manufacturing firms that implement organizational innovation as a percentage of all manufacturing firms

Figure 6. Manufacturing firms that implement organizational innovation by size class as a percentage of manufacturing firms in each size class

Figure 7. Manufacturing firms that implement marketing innovation as a percentage of all manufacturing firms

Figure 8. Manufacturing firms that implement marketing innovation

by size class as a percentage of manufacturing firms in each size class.....

\section{List of text tables}

Table 1. Firms engaged in innovation activities as a percentage of innovation-active manufacturing firms.

Table 2. Highly important sources of information for firms as a percentage of innovation-active manufacturing firms

Table 3.

Cooperation partners of firms as a percentage of innovation-active manufacturing firms .. 20

Table 4.

Highly important cost and economic hampering factors for firms as a percentage of innovation-active manufacturing firms ...

Table 5. Highly important knowledge hampering factors for firms as a percentage of innovation-active manufacturing firms

Table 6. Highly important market hampering factors for firms as a percentage of innovation-active manufacturing firms

\section{List of boxes}

Box 1. Indicator on product or process innovation

Box 2. Innovation activities in BRICS countries 



\section{The 2011 UIS pilot data collection on innovation statistics}

The relationship between innovation and economic development is widely acknowledged. Innovation is a key element in the growth of output and productivity, and therefore crucial for poverty alleviation. While research and experimental development (R\&D) plays a vital role in the innovation process, many of the related activities rely on highly-skilled workers, interactions with other firms and public research institutions, as well as an organizational structure that is conducive to learning and exploiting knowledge (Oslo Manual, §72).

These factors should be taken into account by policymakers. To this end, data are required to better understand innovation and its relation to economic growth, as well as to provide indicators for benchmarking national performance.

Over the last few decades, work has been undertaken to establish analytical frameworks and guidelines for innovation studies. Efforts to standardize innovation definitions and indicators came to the forefront with the publication of the first version of the Oslo Manual (OM) by the Organisation for Economic Co-operation and Development (OECD) in 1992. The manual pushed the measurement of innovation as a process, fostering the collection of comparable innovation indicators since its first edition.

\section{Definition}

An innovation is the implementation of a new or significantly improved product (good or service), or process, a new marketing method, or a new organizational method in business practices, workplace organization or external relations.

A common feature of an innovation is that it must have been implemented. A new or improved product is implemented when it is introduced on the market. New processes, marketing methods or organizational methods are implemented when they are brought into actual use in the firm's operations.

The way innovations spread from their first implementation to different consumers, countries, regions, sectors, markets and firms is known as diffusion. Without diffusion, an innovation has no economic impact (Oslo Manual $^{1} \S 37,146,150$ ).

The UNESCO Institute for Statistics (UIS) is striving to increase the availability of timely, accurate and policy-relevant statistics in the field of science, technology and innovation (STI) through the development of a database of cross-nationally comparable innovation statistics. To this end, the UIS launched a pilot data collection of innovation statistics in 2011 in order to prepare for the global data collection which will be launched in 2013 .

The pilot data collection was based on the definitions of the third edition of the Oslo Manual, covering four types of innovation in the business sector. Data were collected for manufacturing, services and total economic activities covered by each national innovation survey. However, this report focuses exclusively on cross-nationally comparable data for the manufacturing industry. It should be noted that there are certain

1 OECD and Eurostat. (2005). Oslo Manual: Guidelines for Collecting and Interpreting Innovation Data. ( $3^{\text {rd }}$ ed.). Paris: OECD. 
limitations in comparisons between countries due to differences in the methodological procedures of the national innovation surveys.

The pilot data collection sought to gather aggregate data from the most recent national innovation surveys in 19 selected countries. Countries were asked to complete the pilot questionnaire using grossed $u^{2}$ results of their national innovation surveys. The following 12 countries participated in the pilot data collection: Brazil, China, Colombia, Egypt, Ghana, Indonesia, Israel, Malaysia, the Philippines, the Russian Federation, South Africa and Uruguay.

Eurostat has led the way in sustaining the production of internationally comparable data on innovation in enterprises through its Community Innovation Surveys (CIS). Based on the CIS, Eurostat produces innovation statistics for member states and candidate countries of the European Union, Iceland and Norway, which are frequently used for comparison in national innovation survey reports. Therefore, in order to enhance interpretation of the UIS pilot results, whenever possible, this paper compares the data collected with Eurostat's CIS $^{3}$ results from 2006 and 2008.

2 Sample survey data represent units in the sample only. Therefore, the sample estimates need to be inflated to represent the whole population of interest. Estimation is the means by which this inflation occurs, also referred to as "grossing up" (Dodge, Y. (Ed) (2003). The Oxford dictionary of statistical terms. Oxford: Oxford University Press).

3 Eurostat is the statistical office of the European Union. The CIS is designed to monitor innovation activity in Europe and is the main source of statistics on innovation activity of business firms in the region. For more information, see:

http://epp.eurostat.ec.europa.eu/portal/page/portal/science_technology_innovation/data/database. 


\section{Product and process innovation}

Effective policies on innovation must take into account the implementation of product and process innovations by business firms. Product innovations represent the final commercialization of innovation activities on the market and are therefore of great interest to policymakers. Process innovations involve improvements in internal processes, through either the adoption of new technologies or in-house development. Inhouse process innovations are related to the concept of "user innovations", which has recently been attracting extensive interest (Bloch and Lopez-Bassols ${ }^{4}, 2009$ ).

\section{Definition}

Product innovation is the implementation of a good or service that is new or significantly improved with respect to its characteristics or intended uses. This includes significant improvements in technical specifications, components and materials, incorporated software, user friendliness, or other functional characteristics (Oslo Manual §156). Firms that implemented at least one product innovation are product innovators.

Process innovation is the implementation of a new or significantly improved production or delivery method. This includes significant changes in techniques, equipment and/or software (Oslo Manual §163). Firms that implemented at least one process innovation are process innovators.

In contrast to previous editions of the Oslo Manual, the third edition excludes the term technological from the definition of innovation. This is to avoid a narrow interpretation, in particular by firms from the services sector, whereby "technological" implies the use of "high-technology plants and equipment", which would exclude many of the product and process innovations of this specific sector (Oslo Manual §34, 35).

Figure 1 shows the percentage of manufacturing firms that implement product innovation, as well as the percentage of manufacturing firms that implement process innovation.

The Philippines has the highest percentage of manufacturing firms that implement product innovation $(38.0 \%)$, followed by Israel $(34.2 \%)$ and Malaysia $(29.5 \%)$. The Philippines also has the highest share of manufacturing firms that implement process innovation (44.0\%), followed by Malaysia (33.3\%) and Brazil (32.0\%). In contrast, the lowest shares for both product and process innovation are reported by Colombia $(4.6 \%$ and $20.0 \%$ respectively) and Egypt $(6.0 \%$ and $8.3 \%$ respectively).

In China, approximately the same percentage of manufacturing firms implement product $(25.1 \%)$ and process innovation (25.3\%). In Israel, the Russian Federation and South Africa, a higher share of manufacturing firms implement product innovation $(34.2 \%, 8.0 \%$ and $16.8 \%$ respectively) than process innovation (30.9\%, 5.9\% and $13.1 \%$ respectively).

4 Bloch, C. and V. Lopez-Bassols (2009). "Innovation indicators". In OECD (Ed.), Innovation in Firms: A Microeconomic Perspective, (pp. 21-68). Paris: OECD. 
Figure 1. Manufacturing firms that implement product and process innovation as a percentage of all manufacturing firms

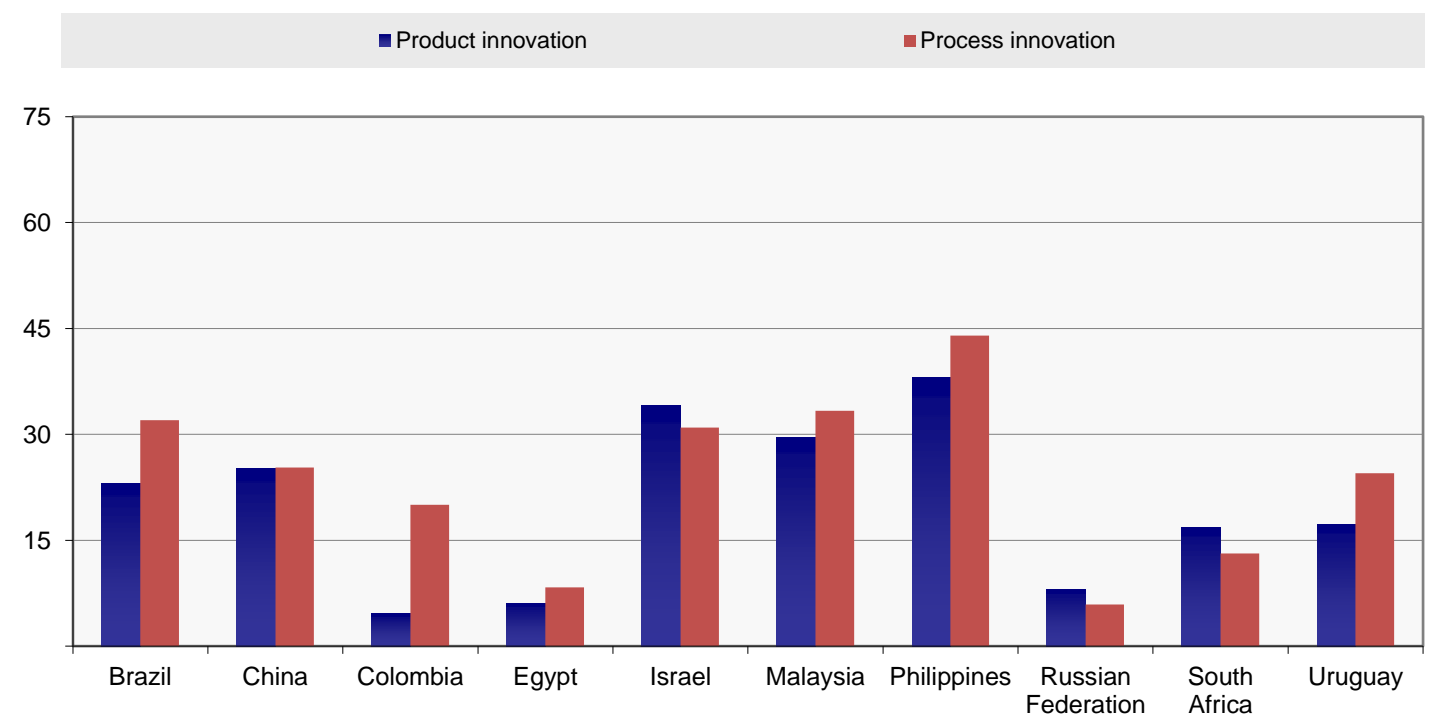

Notes: Based on a three-year observation period, except for the Russian Federation (1 year), the Philippines (1.5 years), Colombia (2 years), and Malaysia (4 years).

For China: Product innovation covers only new or significantly improved goods. Logistics, delivery or distribution methods are not explicitly mentioned in process innovation.

For Colombia: Sample survey data (no grossed up results).

For the Philippines: IT services are also included. Results are not representative of the target population.

Source: 2011 UIS pilot data collection of innovation statistics.

While Figure 1 presents data for product innovation and process innovation separately, Figure 2 shows the percentage of manufacturing firms that implement either product or process innovation.

\section{Box 1. Indicator on product or process innovation}

The indicator on product or process innovation measures the share of firms that implement either product or process innovation in a country as a percentage of all firms. These firms are known as product or process innovators. This indicator usually does not cover firms with abandoned or ongoing innovation activities. In the pilot questionnaire, the share of product or process innovators was restricted to manufacturing firms. Annex I contains detailed data for manufacturing industries at the division level.

The Philippines has the highest share of manufacturing firms that implement either product or process innovation, at 50.2\%. Manufacturing firms in Israel (42.4\%) have approximately the same percentage of product or process innovators as the average of the 27 Member States of the European Union (EU-27) (42.0\%). To some extent, the same can be observed for Malaysia (39.0\%) and Brazil (38\%). 
In the European Union, the highest country share of manufacturing firms that implement product or process innovation (Eurostat max) corresponds to $71.2 \%$. In contrast, the lowest share is $15.0 \%$ for Eurostat countries (Eurostat min). All pilot countries - with the exception of the Russian Federation (11.3\%) and Egypt (9.3\%) - have a share of manufacturing firms that implemented product or process innovation which falls between the Eurostat minimum and maximum shares.

Figure 2. Manufacturing firms that implement product or process innovation as a percentage of all manufacturing firms

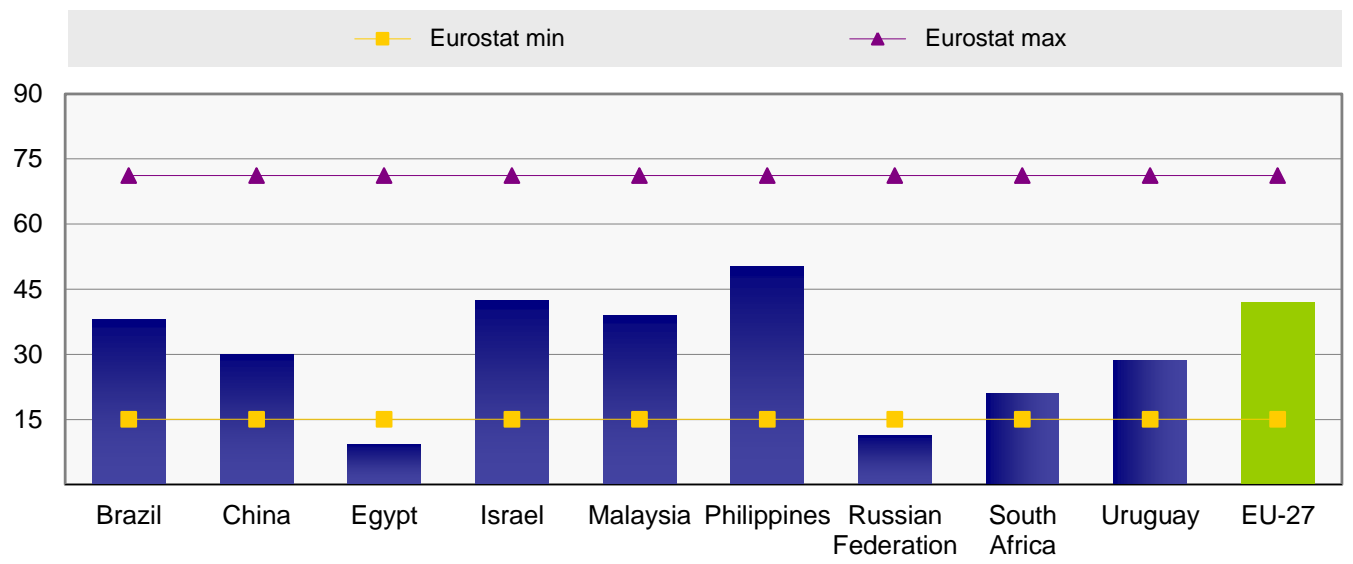

Notes: Based on a three-year observation period, except for the Russian Federation (1 year), the Philippines (1.5 years), and Malaysia (4 years).

For China: Product innovation covers only new or significantly improved goods. Logistics, delivery or distribution methods are not explicitly mentioned in process innovation.

For the Philippines: IT services are also included. Results are not representative of the target population.

For EU-27/Eurostat: Data cover firms with abandoned or ongoing activities.

Source: 2011 UIS pilot data collection of innovation statistics and CIS 2006 database (Eurostat, 2012).

Figure 3 presents the percentage of manufacturing firms that implement either product or process innovation according to their size: micro, small, medium-sized or large. The results support the connection between the size of a firm and its level of innovation. Overall, the larger the size class, the higher the share of firms that implement product or process innovation.

In China, $83.5 \%$ of large manufacturing firms implement product or process innovation, followed by Israel (75.5\%) and the Philippines (60.8\%). In contrast, this was the case for less than one-half of large manufacturing firms in South Africa (20.5\%), the Russian Federation (25.4\%) and Colombia (45.0\%).

Turning to medium-sized manufacturing firms, $57.4 \%$ of these firms implement product or process innovation in Israel and $55.9 \%$ in China. In contrast, this is the case for just $5.4 \%$ of medium-sized manufacturing firms in the Russian Federation.

The share of small manufacturing firms which implement either product or process innovation falls off sharply in countries such as Colombia (14.6\%), South Africa (17.4\%) and China (25.2\%). However, a very different situation emerges in the Philippines and Malaysia, where $45.8 \%$ and $42.1 \%$, respectively, of small manufacturing firms implement product or process innovation. 
Figure 3. Manufacturing firms that implement product or process innovation by size class as a percentage of manufacturing firms in each size class

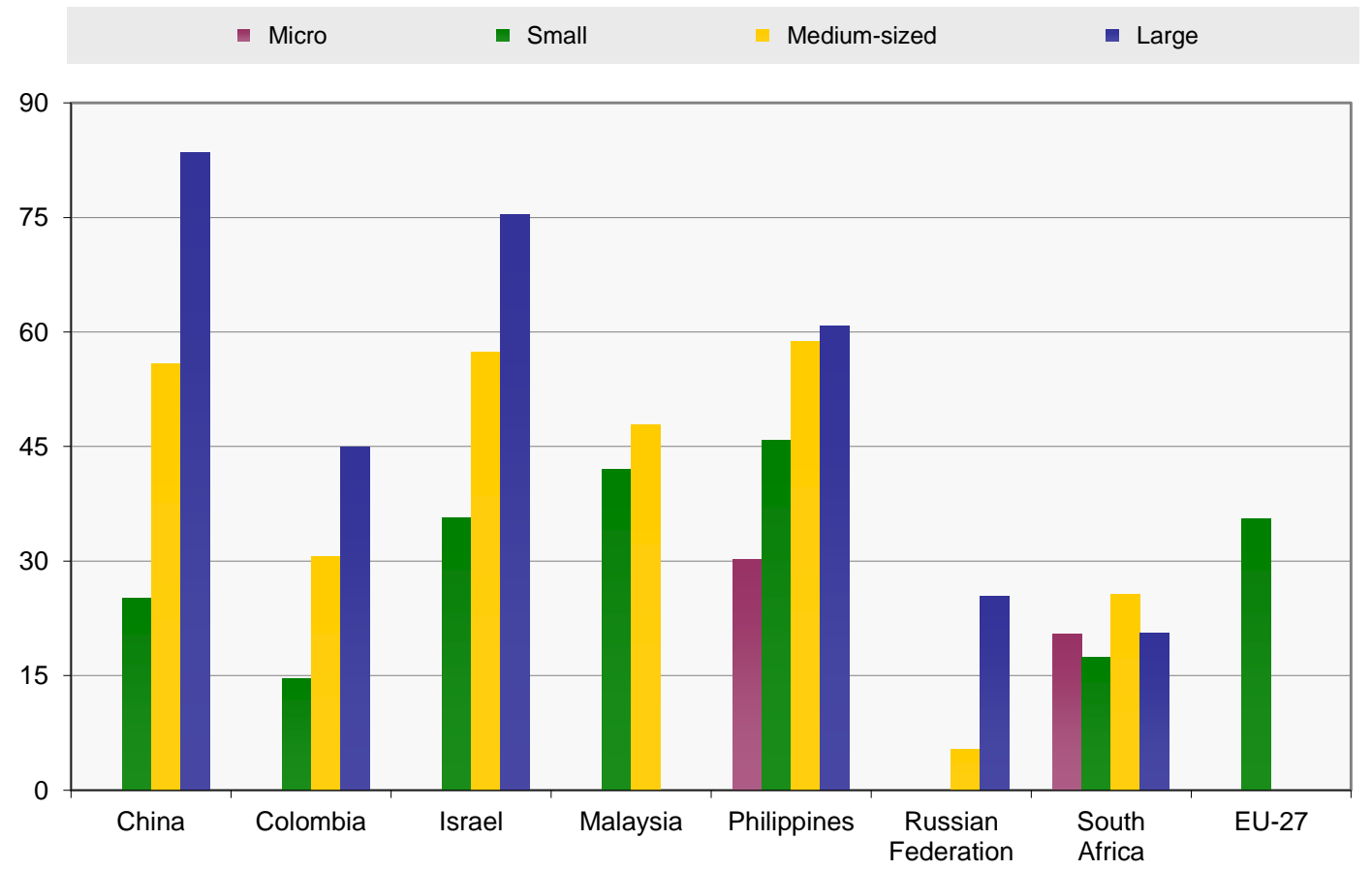

Notes: Based on a three-year observation period, except for the Russian Federation (1 year), the Philippines (1.5 years), Colombia (2 years), and Malaysia (4 years).

For China: Product innovation covers only new or significantly improved goods. Logistics, delivery or distribution methods are not explicitly mentioned in process innovation. Data broken down by size class cover manufacturing, mining and quarrying, as well as electricity, gas and water supply.

For Colombia: Sample survey data (no grossed up results).

For the Philippines: IT services are also included. Results are not representative of the target population.

For EU-27/Eurostat: Data cover firms with abandoned or ongoing activities.

Size classes are detailed in Annex II.

Source: 2011 UIS pilot data collection of innovation statistics and CIS 2006 database (Eurostat, 2012).

South Africa has approximately the same share of micro $(20.4 \%)$ and large $(20.5 \%)$ manufacturing firms which implement product or process innovation. Small firms follow closely behind at $17.4 \%$.

Overall, large manufacturing firms tend to present higher shares of product or process innovators, with the exception of South Africa. In this country, medium-sized manufacturing firms have the highest share of product or process innovators. Moreover, nearly the same percentage of micro and large manufacturing firms implement product or process innovation. This unusual trend could be a topic for further investigation.

In general, the data show that product and process innovation is present in all countries, regardless of their level of development. This underlines the pervasive nature of innovation, especially in contrast to R\&D activities which are generally concentrated in developed countries. 


\section{Innovation activities}

It is important to differentiate between the concept of innovation and innovation activities. An innovation requires a market connection, which is not the case for innovation activities. For example, R\&D or patents without a market connection are considered to be innovation activities but not an innovation (AU-NEPAD $\left.{ }^{5}, 2010\right)$. Innovation activities include: intramural R\&D; extramural R\&D; acquisition of machinery, equipment and software; acquisition of other external knowledge; training; market introduction of innovations; and other preparations.

\section{Definition}

Innovation activities are all scientific, technological, organizational, financial and commercial steps which actually lead, or are intended to lead, to the implementation of innovations. Some innovation activities are innovative, others are not novel activities but are necessary for the implementation of innovations. Innovation activities also include $R \& D$ that is not directly related to the development of a specific innovation (Oslo Manual §149).

Innovation-active firms are those which had implemented, abandoned or ongoing product or process innovation activities during the observation period of a survey. In other words, innovation-active firms are not only the firms that implemented a product or a process innovation but also includes those that had abandoned or ongoing innovation activities to develop new or significantly improved products or processes (Oslo Manual §215).

Table 1 presents the percentage of innovation-active manufacturing firms ${ }^{6}$ engaged in different types of innovation activities.

In eight countries, manufacturing firms are most likely to be involved in the acquisition of machinery, equipment and software. In particular, more than $70 \%$ of firms are engaged in this specific innovation activity in: Colombia (85.8\%), Israel (85.1\%), Ghana $(80.7 \%)$, Egypt (74.3\%) and South Africa (71.2\%). By comparison, the Eurostat maximum is close to $100 \%$ for this activity. Although the greatest share of firms in Uruguay are engaged in the acquisition of machinery, equipment and software, it represents only $20.3 \%$, which is lower than the Eurostat minimum (25.2\%)

Training is also considered to be a major innovation activity. This is the most widely reported type of activity undertaken by firms in Ghana (86.0\%) and China (71.5\%), and is also very important in South Africa (69.6\%). In contrast, the percentages fall considerably in the Russian Federation (18.3\%) and Uruguay (15.1\%). All responding countries present higher shares of firms engaged in this activity than the Eurostat minimum of $8.9 \%$.

5 AU-NEPAD (African Union-New Partnership for Africa's Development). (2010). African Innovation Outlook 2010. Pretoria: AU-NEPAD.

6 In this section the term firms refers to innovation-active manufacturing firms. 
Table 1. Firms engaged in innovation activities as a percentage of innovationactive manufacturing firms

\begin{tabular}{|c|c|c|c|c|c|c|c|}
\hline & \multicolumn{7}{|c|}{ Innovation activity } \\
\hline & $\begin{array}{l}\text { Intramural } \\
R \& D\end{array}$ & $\begin{array}{c}\text { Extramural } \\
R \& D\end{array}$ & $\begin{array}{l}\text { Acquisition of } \\
\text { machinery, } \\
\text { equipment } \\
\text { and software }\end{array}$ & $\begin{array}{c}\text { Acquisition of } \\
\text { other external } \\
\text { knowledge }\end{array}$ & Training & $\begin{array}{c}\text { Market } \\
\text { introduction of } \\
\text { innovations }\end{array}$ & $\begin{array}{l}\text { Other } \\
\text { preparations }\end{array}$ \\
\hline Brazil & 4.7 & 1.9 & 34.1 & 4.8 & 26.5 & 14.7 & 16.7 \\
\hline China & 63.3 & 22.1 & 66.0 & 28.1 & 71.5 & 60.6 & 36.9 \\
\hline Colombia & 26.8 & 8.9 & 85.8 & 7.2 & 19.8 & 26.6 & n.a. \\
\hline Egypt & 41.3 & 5.5 & 74.3 & 11.0 & 56.9 & 19.3 & 35.8 \\
\hline Ghana & 42.1 & 14.0 & 80.7 & 15.8 & 86.0 & 71.9 & 45.6 \\
\hline Indonesia & 48.3 & 5.2 & 39.3 & 21.6 & 37.0 & 85.4 & 77.5 \\
\hline Israel & 48.9 & 32.2 & 85.1 & 12.9 & 52.6 & 59.1 & n.a. \\
\hline Malaysia & 42.5 & 15.8 & 64.9 & 29.8 & 50.2 & 32.0 & n.a. \\
\hline Philippines & n.a. & n.a. & n.a. & n.a. & n.a. & n.a. & n.a. \\
\hline Russian Federation & 18.9 & 20.0 & 64.0 & 12.7 & 18.3 & 9.6 & n.a. \\
\hline South Africa & 54.1 & 22.4 & 71.2 & 24.8 & 69.6 & 42.6 & 47.7 \\
\hline Uruguay & 11.1 & 1.2 & 20.3 & 4.4 & 15.1 & n.a. & n.a. \\
\hline EU-27 & n.a. & n.a. & n.a. & n.a. & n.a. & n.a. & n.a. \\
\hline Eurostat min & 8.2 & 5.8 & 25.2 & 2.0 & 8.9 & 14.3 & 9.4 \\
\hline Eurostat max & 81.3 & 54.8 & 98.8 & 53.1 & 96.4 & 48.4 & 88.1 \\
\hline
\end{tabular}

Notes: Based on a three-year observation period, except for the Russian Federation (1 year), the Philippines (1.5 years), Colombia (2 years), Indonesia (2 years), and Malaysia (4 years).

For Colombia: Sample survey data (no grossed up results). Data only cover product and process innovators. Acquisition of software is not included. Acquisition of other external knowledge is categorised under technology transfer.

For Ghana: Data only cover product and process innovators.

For Indonesia: The target population was medium-sized and large firms that implemented any type of innovation. No specification of firms covered.

For Malaysia: Data also cover organizational and marketing innovators.

For the Philippines: IT services are also included. Results are not representative of the target population.

For the Russian Federation: Acquisition of software is not included.

For Uruguay: Data cover organizational and marketing innovators and exclude firms with abandoned or ongoing activities. Acquisition of machinery, equipment and software refers to acquisition of capital goods. Acquisition of other external knowledge is categorized under technology transfer and consultancy.

Source: 2011 UIS pilot data collection of innovation statistics and CIS 2008 database (Eurostat, 2012).

Significant percentages of firms are also engaged in intramural $R \& D$ and the market introduction of innovations. In China, $63.3 \%$ of firms engaged in intramural R\&D, which is the case for $54.1 \%$ of firms in South Africa. In Indonesia, $85.4 \%$ of firms engaged in market introduction of innovations, followed by Ghana (71.9\%), China (60.6\%) and Israel $(59.1 \%)$. All these countries present a share of firms engaged in market introduction of innovations higher the Eurostat maximum (48.4\%).

In contrast, the two activities in which firms are the least likely to engage are: the acquisition of other external knowledge and extramural R\&D. Extramural R\&D, in particular, has the lowest shares of engagement in seven countries. Israel (32.2\%) has the highest percentage of firms engaged in this activity, followed by South Africa 
(22.4\%), China (22.1\%) and the Russian Federation (20.0\%). Interestingly, the Russian Federation is the only country to have more firms engaged in extramural R\&D than intramural R\&D (18.9\%).

\section{Box 2. Innovation activities in BRICS countries}

India is the only BRICS country that was not included in the 2011 UIS Pilot Data Collection of Innovation Statistics, since the results of the Indian Innovation Survey were not yet available when the pilot was launched. While China and South Africa alternate in taking the lead with the highest share of firms engaged in innovation activities, Brazil and the Russian Federation interchange with the lowest percentages.

In three of the four BRICS countries covered in the pilot, most firms engaged in the acquisition of machinery, equipment and software: South Africa $(71.2 \%)$, the Russian Federation $(64.0 \%)$ and Brazil (34.1\%). In the fourth country, China, most firms engaged in training (71.5\%).

In brief, the results support the ideas that innovation is broader than R\&D and that technology transfer in the form of acquisition of machinery, equipment and software is important. Indeed, the latter is the lead innovation activity, followed by training. In contrast, only two countries reported more than one-half of their firms being engaged in intramural R\&D. Furthermore, the results show that none of the responding countries have more than $50 \%$ of their firms engaged in extramural R\&D. 


\section{Sources of information}

From a policymaking perspective, it is important to clearly identify the linkages that firms ${ }^{7}$ rely on to foster innovation. Linkages are considered to be sources of knowledge and technology, ranging from passive sources of information to suppliers of embodied and disembodied knowledge and technology to cooperative partnerships. Each linkage connects the firm to other agents in the innovation system: government laboratories, universities, policy departments, regulators, competitors, suppliers and customers (Oslo Manual §252-254).

There are three types of external linkages or flows of knowledge and technologies to firms: i) open information sources that do not involve purchases of knowledge and technology or interaction with the source; ii) purchases or acquisition of knowledge and technology; and iii) innovation cooperation (Oslo Manual §264). This section focuses on sources of information.

\section{Definition}

The innovative activities of a firm partly depend on the variety and structure of its links to sources of information, knowledge, technologies, practices, and human and financial resources (Oslo Manual §252). Sources of information are the sources that provide information for new innovation projects or contribute to the completion of existing innovation projects.

Table 2 presents the sources of information which firms rated as being highly important. Internal sources are considered to be highly important by a majority of firms in the following countries: Egypt (84.4\%), Malaysia (72.0\%), the Philippines (70.0\%), Israel (66.3\%), South Africa (44.0\%), Ghana (43.9\%) and Uruguay (39.4).

The second most valued source of information for firms are clients or customers. The following countries had the greatest share of firms rating this source of information as highly important: Indonesia (81.0\%), China (59.7\%), Brazil $(46.0 \%)$ and the Russian Federation (34.9\%).

In contrast, institutional sources are the least likely to be rated as highly important. In almost all countries - with the exception of China - less than $20 \%$ of firms considered universities or other higher education institutions and government or public research institutes as highly important sources of information.

Finally, in 5 of the 12 responding countries - namely Brazil, Ghana, the Russian Federation, South Africa and Uruguay - no source is considered to be highly important by more than $50 \%$ of their firms.

\section{Box 3. Sources of information in Malaysia}

Of the responding countries, Malaysia has the highest share of firms (17.1\%) that consider universities or other higher education institutions to be highly important sources of information. Nonetheless, this percentage is much lower than the $72 \%$ of firms in the country that rated internal sources as a highly important source of information.

\footnotetext{
7 In this section the term firms refers to innovation-active manufacturing firms.
} 
Table 2. Highly important sources of information for firms as a percentage of innovation-active manufacturing firms

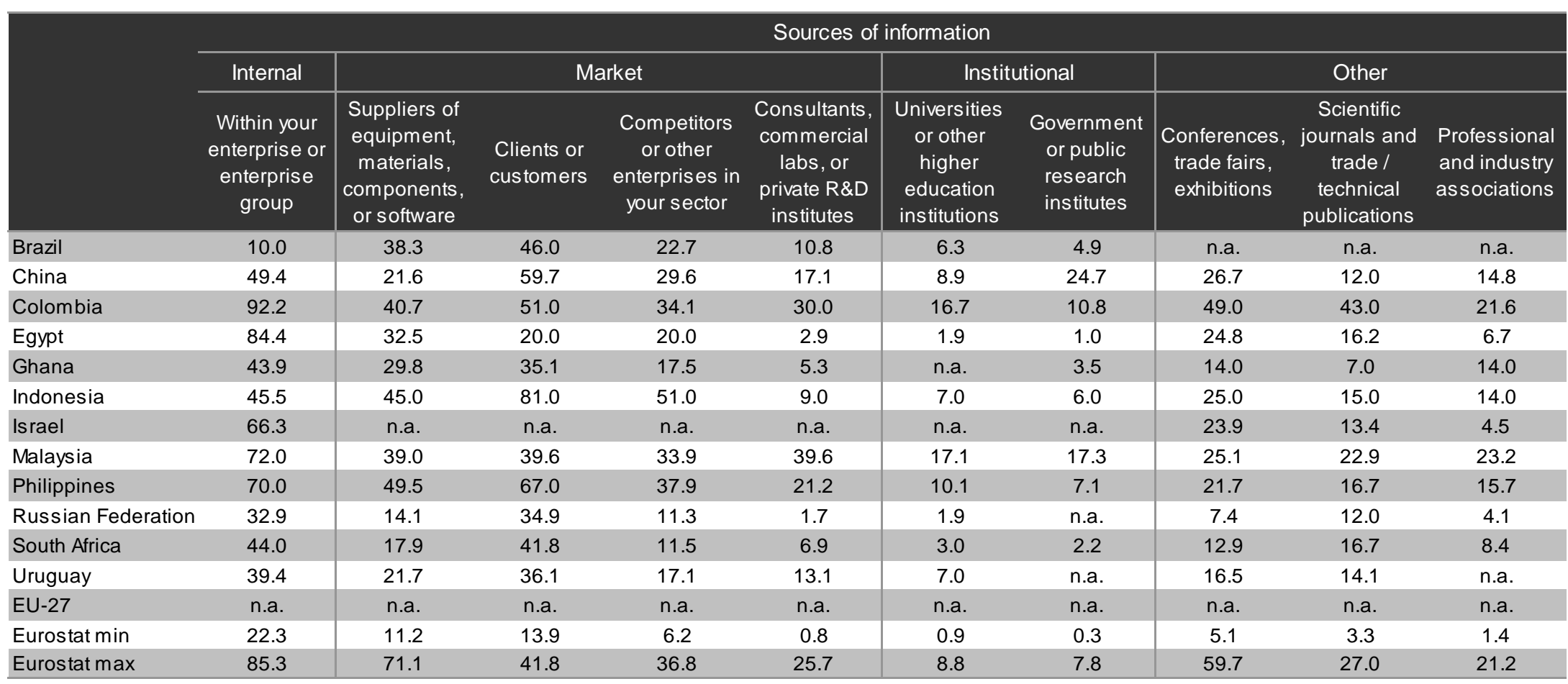

Notes: Based on a three-year observation period, except for the Russian Federation (1 year), the Philippines (1.5 years), Colombia (2 years), Indonesia (2 years), and Malaysia (4 years).

For Colombia: Sample survey data (no grossed up results). Data only cover product and process innovators. Question based on dichotomous (yes/no) responses.

For Ghana: Data only cover product and process innovators.

For Indonesia: The target population was medium-sized and large firms that implemented any type of innovation. No specification of firms covered.

For Malaysia: Data also cover organizational and marketing innovators.

For the Philippines: IT services are also included. Results are not representative of the target population.

For the Russian Federation: Data also cover organizational and marketing innovators. Internal sources do not cover enterprise group.

For Uruguay: Data cover organizational and marketing innovators and exclude firms with abandoned or ongoing activities.

Source: 2011 UIS pilot data collection of innovation statistics and CIS 2008 database (Eurostat, 2012). 


\section{Cooperation}

Innovation cooperation is distinct from open information sources and acquisition of knowledge and technology in that all parties take an active part in the work. There is also great potential for synergies in cooperation as partners learn from each other. It allows firms to access knowledge and technology that they would be unable to utilise on their own (Oslo Manual §271-272).

Innovation cooperation can take place along supply chains and involve customers and suppliers in the joint development of new products, processes or other innovations. Exchange of technological and business information naturally accompanies the trade of goods and services. Information on customer needs and their experience with a supplier's product plays a key role in innovation. Innovation cooperation can also involve horizontal collaboration, with firms working jointly with other firms or public research institutions (Oslo Manual §273-274).

\section{Definition}

Cooperation is the active participation in joint innovation projects with other organizations. These may either be other firms or non-commercial institutions. The partners need not derive immediate commercial benefit from the venture. Pure contracting out of work, where there is no active collaboration, is not regarded as cooperation (Oslo Manual §271).

Figure 4 presents a general overview of the percentage of firms ${ }^{8}$ engaged in joint innovation projects. In Colombia, $47.8 \%$ of firms have innovation projects with partners, followed by the Russian Federation (37.3\%), Israel (33.4\%) and South Africa (33.0\%). In contrast, only $7.5 \%$ of firms cooperated with partners in Egypt and $9.7 \%$ of firms in Brazil, both lower than the Eurostat minimum (12.9\%).

Table 3 presents more detailed data on the type of partners involved in cooperation agreements associated with innovation activities. The most frequent cooperation partners are suppliers of equipment, materials, components or software in the following responding countries: Indonesia $(66.3 \%)$, Colombia $(31.8 \%)$, the Russian Federation (16.9\%) and Brazil (5.0\%).

Clients or customers are leading partners in: the Philippines (94.1\%), South Africa (31.7\%), Ghana (31.6\%), and Israel (21.3\%).

In general, most firms did not cooperate on a large scale with universities or other higher education institutions, as well as government or public research institutes. This suggests the need to strengthen relations between the private, educational and public sectors.

A wide variation is observed in the percentage of firms cooperating with consultant, commercial laboratories or private $R \& D$ institutes, ranging from $1.9 \%$ in Brazil to $84.0 \%$ in Malaysia.

\footnotetext{
8 In this section the term firms refers to innovation-active manufacturing firms.
} 
Figure 4. Firms with cooperation partners as a percentage of innovation-active manufacturing firms

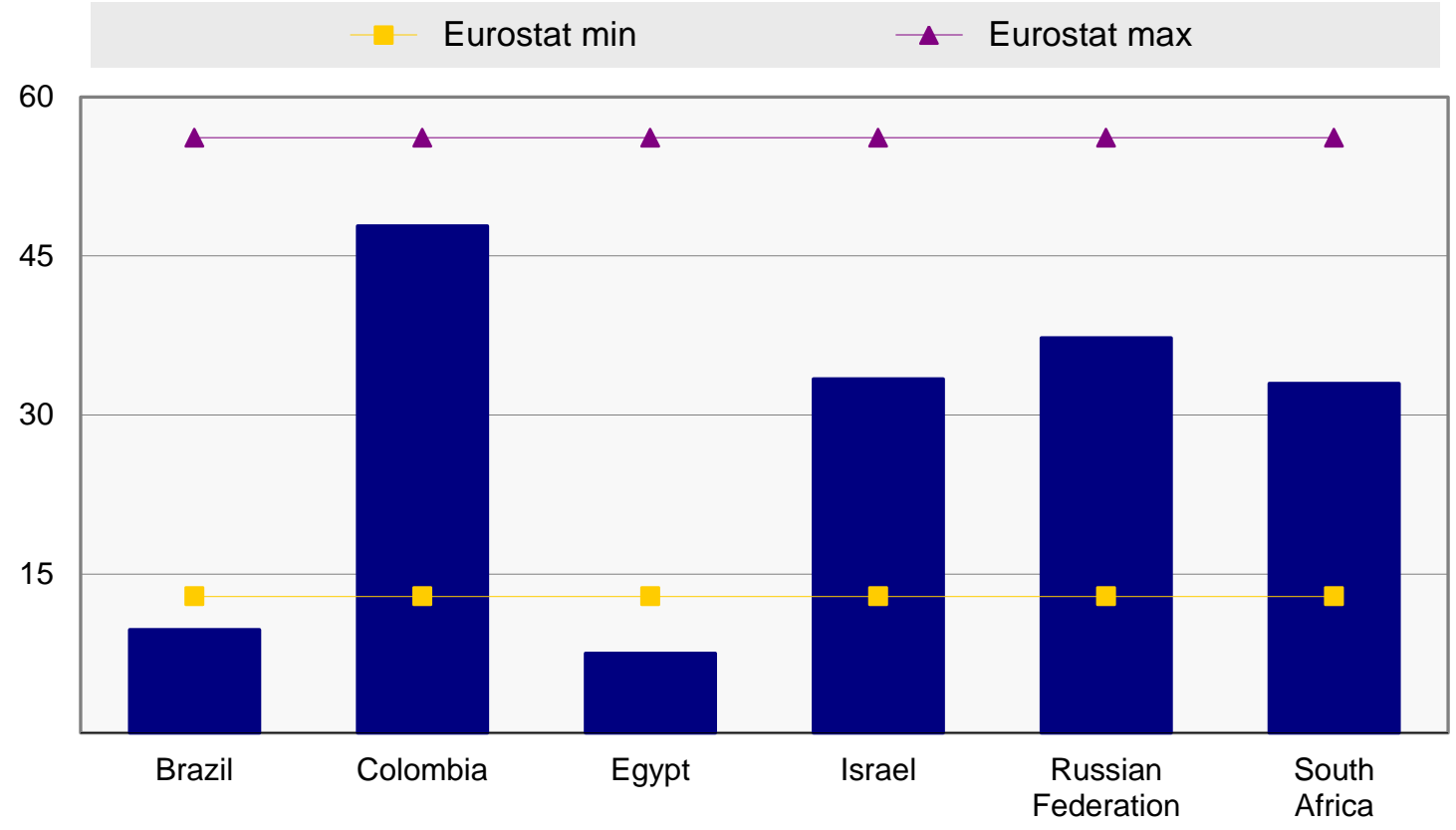

Notes: Based on a three-year observation period, except for the Russian Federation (1 year) and Colombia (2 years).

For Colombia: Sample survey data (no grossed up results). Data only cover product and process innovators.

For the Russian Federation: Data also cover organizational and marketing innovators.

Source: 2011 UIS pilot data collection of innovation statistics and CIS 2008 database (Eurostat, 2012).

\section{Box 4. Cooperation in Brazil}

Of the responding countries, Brazil has the lowest share of firms actively participating in joint innovation projects, at just below $10 \%$. As shown in Table 3 , this trend is observed across all possible partner organizations, with Brazil having the lowest percentage of firms in all categories. 
Table 3. Cooperation partners of firms as a percentage of innovation-active manufacturing firms

\begin{tabular}{|c|c|c|c|c|c|c|c|c|}
\hline & \multicolumn{8}{|c|}{ Cooperation partner } \\
\hline & $\begin{array}{c}\text { Any type of } \\
\text { co-operation } \\
\text { partner }\end{array}$ & $\begin{array}{c}\text { Other } \\
\text { enterprises } \\
\text { within your } \\
\text { enterprise group }\end{array}$ & $\begin{array}{c}\text { Suppliers of } \\
\text { equipment, } \\
\text { materials, } \\
\text { components, or } \\
\text { software }\end{array}$ & $\begin{array}{l}\text { Clients or } \\
\text { customers }\end{array}$ & $\begin{array}{l}\text { Competitors or } \\
\text { other } \\
\text { enterprises in } \\
\text { your sector }\end{array}$ & $\begin{array}{l}\text { Consultants, } \\
\text { commercial } \\
\text { labs, or private } \\
\text { R\&D institutes }\end{array}$ & $\begin{array}{l}\text { Universities or } \\
\text { other higher } \\
\text { education } \\
\text { institutions }\end{array}$ & $\begin{array}{l}\text { Government or } \\
\text { public research } \\
\text { institutes }\end{array}$ \\
\hline Brazil & 9.7 & 1.1 & 5.0 & 3.5 & 1.0 & 1.9 & 1.9 & n.a. \\
\hline China & n.a. & n.a. & n.a. & n.a. & n.a. & n.a. & n.a. & n.a. \\
\hline Colombia & 47.8 & 18.3 & 31.8 & 24.9 & 5.8 & 20.7 & 14.9 & n.a. \\
\hline Egypt & 7.5 & n.a. & n.a. & n.a. & n.a. & n.a. & n.a. & n.a. \\
\hline Ghana & n.a. & 28.1 & 21.1 & 31.6 & 17.5 & 22.8 & 12.3 & 8.8 \\
\hline Indonesia & n.a. & 37.8 & 66.3 & n.a. & 18.4 & 24.5 & 19.4 & 11.2 \\
\hline Israel & 33.4 & 8.3 & 19.6 & 21.3 & 14.4 & 17.3 & 12.6 & 8.2 \\
\hline Malaysia & n.a. & 65.5 & 55.1 & 56.1 & 30.0 & 84.0 & 45.0 & 37.0 \\
\hline Philippines & n.a. & 91.2 & 92.6 & 94.1 & 67.6 & 64.7 & 47.1 & 50.0 \\
\hline Russian Federation & 37.3 & 12.6 & 16.9 & 10.9 & 3.9 & 5.1 & 9.1 & 15.6 \\
\hline South Africa & 33.0 & 14.2 & 30.3 & 31.7 & 18.6 & 21.1 & 16.2 & 16.2 \\
\hline Uruguay & n.a. & n.a. & n.a. & n.a. & n.a. & n.a. & n.a. & n.a. \\
\hline EU-27 & n.a. & n.a. & n.a. & n.a. & n.a. & n.a. & n.a. & n.a. \\
\hline Eurostat min & 12.9 & 2.4 & 7.1 & 4.2 & 2.7 & 4.4 & 4.3 & 1.1 \\
\hline Eurostat max & 56.2 & 23.0 & 41.5 & 36.0 & 30.8 & 33.9 & 30.8 & 26.3 \\
\hline
\end{tabular}

Notes: Based on a three-year observation period, except for the Russian Federation (1 year), the Philippines (1.5 years), Colombia (2 years), Indonesia (2 years), and Malaysia (4 years).

For Colombia: Sample survey data (no grossed up results). Data only cover product and process innovators.

For Ghana: Data only cover product and process innovators.

For Indonesia: The target population was medium-sized and large firms that implemented any type of innovation. No specification of firms covered.

For Malaysia: Data also cover organizational and marketing innovators.

For the Philippines: IT services are also included. Results are not representative of the target population.

For the Russian Federation: Data also cover organizational and marketing innovators.

Source: 2011 UIS pilot data collection of innovation statistics and CIS 2008 database (Eurostat, 2012). 


\section{Factors hampering innovation activities}

Policymakers and business leaders need accurate information on factors that support innovation, as well as the barriers which can hamper it. These impediments may take many forms but can be categorised as a lack of: available financing; demand for new products; skilled personnel; suitable partners for joint innovation projects; and knowledge relating to technologies or markets needed to develop an innovation (Oslo Manual $\S 411)$.

For this report, these hampering factors have been divided into the following categories: cost and economic; knowledge; and market factors. Other factors are found in Annex I, which also contains detailed data for non-innovative firms.

\section{Definitions}

Innovation activity may be hampered by a number of factors. There may be reasons for not starting innovation activities at all; there may be factors that slow innovation activity or affect them negatively. These hampering factors include: economic factors, such as high costs or lack of demand; knowledge factors, such as lack of skilled personnel; market factors, such as uncertainty in the demand for innovative products; and other factors, such as regulations (Oslo Manual §410).

Table 4 presents the percentage of firms ${ }^{9}$ which rated different types of cost and economic factors as highly important barriers to innovation activities or projects.

A lack of funds within the enterprise or enterprise group is considered to be a highly important impediment to innovation by most firms in seven of the responding countries. This is particularly the case in Ghana with $47.4 \%$ of firms rating this hampering factor as highly important, followed by Indonesia (46.0\%) and Colombia (42.1\%).

The high cost of innovation is the impeding factor rated as highly important by the highest percentages of firms in: Indonesia (46.0\%), Malaysia (41.3\%), Brazil $(21.6 \%)$ and the Philippines (20.9\%).

Table 5 presents the percentage of firms which rated different types of knowledge factors as highly important barriers to innovation activities or projects.

In 7 out of 12 responding countries, a lack of qualified personnel is considered to be a highly important factor hampering innovation by the majority of firms. This is the case, for instance, for almost one-third of firms in Uruguay (32.4\%) and Malaysia (28.7\%).

In Colombia, $42.3 \%$ of firms considered a lack of information on technology to be a highly important hampering factor. Meanwhile, 37.0\% of firms in Egypt are hindered by a lack of information on markets. Finally, difficulty in finding cooperation partners for innovation is rated as a highly important impediment by the highest shares of firms in Indonesia (36.0\%) and Ghana (17.5\%).

9 In this section the term firms refers to innovation-active manufacturing firms. 
Table 4. Highly important cost and economic hampering factors for firms as a percentage of innovation-active manufacturing firms

\begin{tabular}{|c|c|c|c|c|}
\hline & & Cost and eco & nomic factors & \\
\hline & $\begin{array}{l}\text { Lack of funds within } \\
\text { your enterprise or } \\
\text { group }\end{array}$ & $\begin{array}{l}\text { Lack of finance from } \\
\text { sources outside your } \\
\text { enterprise }\end{array}$ & $\begin{array}{c}\text { Innovation costs too } \\
\text { high }\end{array}$ & $\begin{array}{c}\text { Excessive perceived } \\
\text { economic risks }\end{array}$ \\
\hline Brazil & n.a. & 17.5 & 21.6 & 17.7 \\
\hline China & n.a. & n.a. & n.a. & n.a. \\
\hline Colombia & 42.1 & 33.8 & n.a. & n.a. \\
\hline Egypt & 28.6 & 28.6 & 21.8 & n.a. \\
\hline Ghana & 47.4 & 28.2 & 38.6 & n.a. \\
\hline Indonesia & 46.0 & 44.0 & 46.0 & 44.0 \\
\hline Israel & 26.5 & 11.1 & 21.4 & n.a. \\
\hline Malaysia & 29.3 & 40.3 & 41.3 & 33.8 \\
\hline Philippines & 19.1 & 10.2 & 20.9 & n.a. \\
\hline Russian Federation & 39.8 & n.a. & 27.8 & 16.3 \\
\hline South Africa & 38.0 & 23.5 & 33.5 & n.a. \\
\hline Uruguay & n.a. & 24.8 & n.a. & 15.0 \\
\hline EU-27 & n.a. & n.a. & n.a. & n.a. \\
\hline Eurostat min & 11.0 & 4.4 & 9.6 & n.a. \\
\hline Eurostat max & 42.1 & 36.6 & 44.0 & n.a. \\
\hline
\end{tabular}

Notes: Based on a three-year observation period, except for the Russian Federation (1 year), the Philippines (1.5 years), Colombia (2 years), Indonesia (2 years), and Malaysia (4 years).

For Colombia: Sample survey data (no grossed up results). Data only cover product and process innovators.

For Ghana: Data only cover product and process innovators.

For Indonesia: The target population was medium-sized and large firms that implemented any type of innovation. No specification of firms covered.

For Malaysia: Data also cover organizational and marketing innovators.

For the Philippines: IT services are also included. Results are not representative of the target population.

For the Russian Federation: Data also cover organizational and marketing innovators.

For Uruguay: Data cover organizational and marketing innovators and exclude firms with abandoned or ongoing activities.

Source: 2011 UIS pilot data collection of innovation statistics and CIS 2006 database (Eurostat, 2012). 
Table 5. Highly important knowledge hampering factors for firms as a percentage of innovation-active manufacturing firms

\begin{tabular}{|c|c|c|c|c|}
\hline & \multicolumn{4}{|c|}{ Knowledge factors } \\
\hline & $\begin{array}{c}\text { Lack of qualified } \\
\text { personnel }\end{array}$ & $\begin{array}{l}\text { Lack of information } \\
\text { on technology }\end{array}$ & $\begin{array}{l}\text { Lack of information } \\
\text { on markets }\end{array}$ & $\begin{array}{l}\text { Difficulty in finding } \\
\text { cooperation partners } \\
\text { for innovation }\end{array}$ \\
\hline Brazil & 16.2 & 5.9 & 4.4 & 7.1 \\
\hline China & 28.0 & n.a. & n.a. & n.a. \\
\hline Colombia & 41.5 & 42.3 & 41.3 & 31.2 \\
\hline Egypt & 29.4 & 36.1 & 37.0 & 27.7 \\
\hline Ghana & 14.1 & 7.0 & 8.8 & 17.5 \\
\hline Indonesia & 29.0 & 29.0 & 23.0 & 36.0 \\
\hline Israel & 16.0 & 5.5 & 4.5 & 6.3 \\
\hline Malaysia & 28.7 & 25.6 & 22.9 & 22.6 \\
\hline Philippines & 11.7 & 8.2 & 10.0 & 5.6 \\
\hline Russian Federation & 5.3 & 1.8 & 2.9 & 1.6 \\
\hline South Africa & 23.0 & 11.9 & 11.7 & 13.1 \\
\hline Uruguay & 32.4 & 7.3 & 11.3 & 16.4 \\
\hline EU-27 & n.a. & n.a. & n.a. & n.a. \\
\hline Eurostat min & 8.1 & 2.0 & 1.6 & 2.5 \\
\hline Eurostat max & 26.6 & 35.0 & 36.4 & 23.4 \\
\hline
\end{tabular}

Notes: Based on a three-year observation period, except for the Russian Federation (1 year), the Philippines (1.5 years), Colombia (2 years), Indonesia (2 years), and Malaysia (4 years).

For China: Lack of qualified personnel refers to a lack of technical personnel or 'brain drain' of technical talents.

For Colombia: Sample survey data (no grossed up results). Data only cover product and process innovators.

For Ghana: Data only cover product and process innovators.

For Indonesia: The target population was medium-sized and large firms that implemented any type of innovation. No specification of firms covered.

For Malaysia: Data also cover organizational and marketing innovators.

For the Philippines: IT services are also included. Results are not representative of the target population.

For the Russian Federation: Data also cover organizational and marketing innovators.

For Uruguay: Data cover organizational and marketing innovators and exclude firms with abandoned or ongoing activities.

Source: 2011 UIS pilot data collection of innovation statistics and CIS 2006 database (Eurostat, 2012). 
Table 6 presents the percentage of firms which rated different types of market factors as highly important barriers to innovation activities or projects.

Market domination by established enterprises is considered as a highly important barrier to innovation by the majority of firms in: Indonesia (37.0\%), Malaysia (30.7\%), Ghana (19.3\%), South Africa (17.5\%), the Philippines (14.7\%) and Israel (10.7\%). In Colombia and Egypt, uncertain demand for innovative goods or services is rated as a highly important hampering factor by $44.5 \%$ and $29.4 \%$ of firms respectively.

\section{Table 6. Highly important market hampering factors for firms as a percentage of innovation-active manufacturing firms}

\begin{tabular}{lccc} 
& & Market factors & \\
\cline { 2 - 4 } & $\begin{array}{c}\text { Market dominated by } \\
\text { established enterprises }\end{array}$ & $\begin{array}{c}\text { Uncertain demand for } \\
\text { innovative goods or services }\end{array}$ & $\begin{array}{c}\text { Innovation is } \\
\text { easy to imitate }\end{array}$ \\
\hline Brazil & n.a. & n.a. & n.a. \\
China & n.a. & n.a. & 12.3 \\
Colombia & n.a. & 44.5 & 34.7 \\
Egypt & 26.1 & 29.4 & n.a. \\
Ghana & 19.3 & 12.3 & n.a. \\
Indonesia & 37.0 & 31.0 & n.a. \\
Israel & 10.7 & 6.2 & n.a. \\
Malaysia & 30.7 & 21.5 & n.a. \\
Philippines & 14.7 & 9.9 & n.a. \\
Russia Federation & n.a. & 9.1 & n.a. \\
South Africa & 17.5 & 15.5 & n.a. \\
Uruguay & n.a. & n.a. & n.a. \\
EU-27 & n.a. & n.a. & n.a. \\
Eurostat min & 5.3 & 4.5 & n.a. \\
\hline Eurostat max & 26.0 & 24.3 & n.a. \\
\hline
\end{tabular}

Notes: Based on a three-year observation period, except for the Russian Federation (1 year), the Philippines (1.5 years), Colombia (2 years), Indonesia (2 years), and Malaysia (4 years).

For China: Innovation is easy to imitate refers to counterfeiting or import competition.

For Colombia: Sample survey data (no grossed up results). Data only cover product and process innovators.

For Ghana: Data only cover product and process innovators.

For Indonesia: The target population was medium-sized and large firms that implemented any type of innovation. No specification of firms covered.

For Malaysia: Data also cover organizational and marketing innovators.

For the Philippines: IT services are also included. Results are not representative of the target population.

For the Russian Federation: Data also cover organizational and marketing innovators.

For Uruguay: Data cover organizational and marketing innovators and exclude firms with abandoned or ongoing activities.

Source: 2011 UIS pilot data collection of innovation statistics and CIS 2006 database (Eurostat, 2012). 


\section{Organizational innovation}

The definition of innovation has evolved to include organizational and marketing innovation (see third edition of the Oslo Manual). This change was intended to allow for more extensive analysis of the interactions between different types of innovations, in particular the importance of implementing organizational changes in order to benefit from other types of innovations (Oslo Manual §12).

It is important to note that organizational innovations are not only a supporting factor for product and process innovations; they can also have an important impact on firm performance. Organizational innovations can improve the quality and efficiency of work, enhance the exchange of information, and improve a firm's ability to learn and utilise new knowledge and technologies incorporated in machinery and other equipment. This is particularly important for developing countries (Oslo Manual §11 and Annex A §500).

\section{Definition}

Organizational innovation is the implementation of a new organizational method in the firm's business practices, workplace organization or external relations (Oslo Manual §177). Firms that implemented at least one organizational innovation are organizational innovators.

Figure 5 shows the percentage of manufacturing firms that implement organizational innovation.

In the Philippines, $58.0 \%$ of firms implement organizational innovation. This is followed by Brazil (54.0\%) and South Africa (52.6\%). These three countries exceed the Eurostat maximum $(51.9 \%)$, which can be an indication of the relevance of organizational innovation for developing and emerging countries. A high share of firms in Israel $(50.6 \%)$ also implement organizational innovation. In contrast, low percentages are reported in the Russian Federation (4.0\%), Egypt (6.2\%) and Uruguay (8.4\%) - three countries which have lower rates than the Eurostat minimum (10.1\%).

\section{Box 5. Annex to the Oslo Manual}

The Annex to the Oslo Manual on Innovation Surveys in Developing Countries stresses the importance of organizational innovation for firms in developing countries, which often lack formal organizational structures (OM Annex A, §500). The preparation of the material for this annex was coordinated by the UIS. 
Figure 5. Manufacturing firms that implement organizational innovation as a percentage of all manufacturing firms

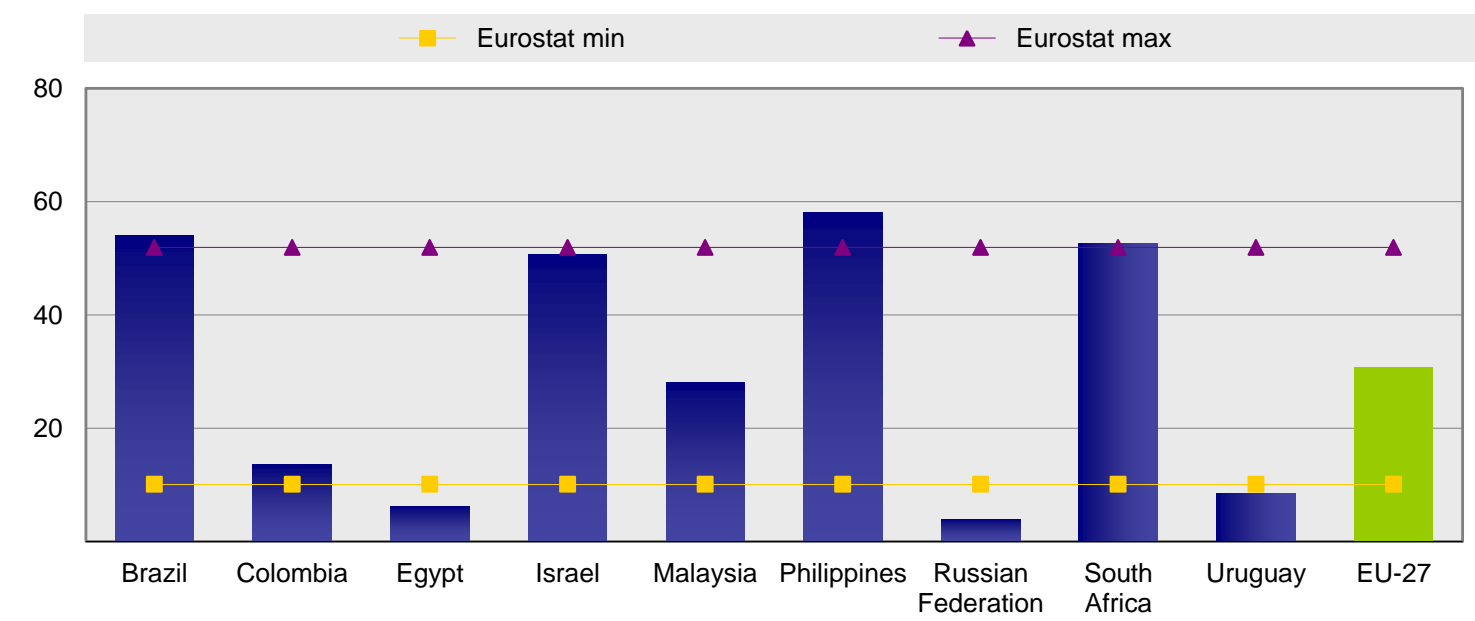

Notes: Based on a three-year observation period, except for the Russian Federation (1 year), the Philippines (1.5 years), Colombia (2 years), and Malaysia (4 years).

For Brazil: Environmental management techniques are included and methods to organize external relations can be new or significantly changed.

For Colombia: Sample survey data (no grossed up results).

For the Philippines: IT services are also included. Results are not representative of the target population.

For Egypt, Malaysia, the Philippines and South Africa: Organizational innovation includes new or significant changes.

Source: 2011 UIS pilot data collection of innovation statistics and CIS 2008 database (Eurostat, 2012).

Figure 6 shows the percentage of manufacturing firms that implement organizational innovation according to their size: micro, small, medium-sized or large.

Overall, the large size class has the highest share of firms that implement organizational innovation, as can be seen in Israel (72.0\%) and South Africa (71.1\%).

The only exception is the Philippines. Although a significant percentage of large manufacturing firms (67.0\%) implement this type of innovation, medium-sized manufacturing firms have the highest share of organizational innovators (70.0\%). In all other countries, the medium-sized class has the second highest shares of manufacturing firms that implement organizational innovation.

The lowest percentages of manufacturing firms that implement organizational innovation are observed in the small and micro size classes. Furthermore, two countries - Egypt and the Russian Federation - have the smallest percentage of manufacturing firms overall implementing this kind of innovation, at below $20 \%$ in all size classes. 
Figure 6. Manufacturing firms that implement organizational innovation by size class as a percentage of manufacturing firms in each size class

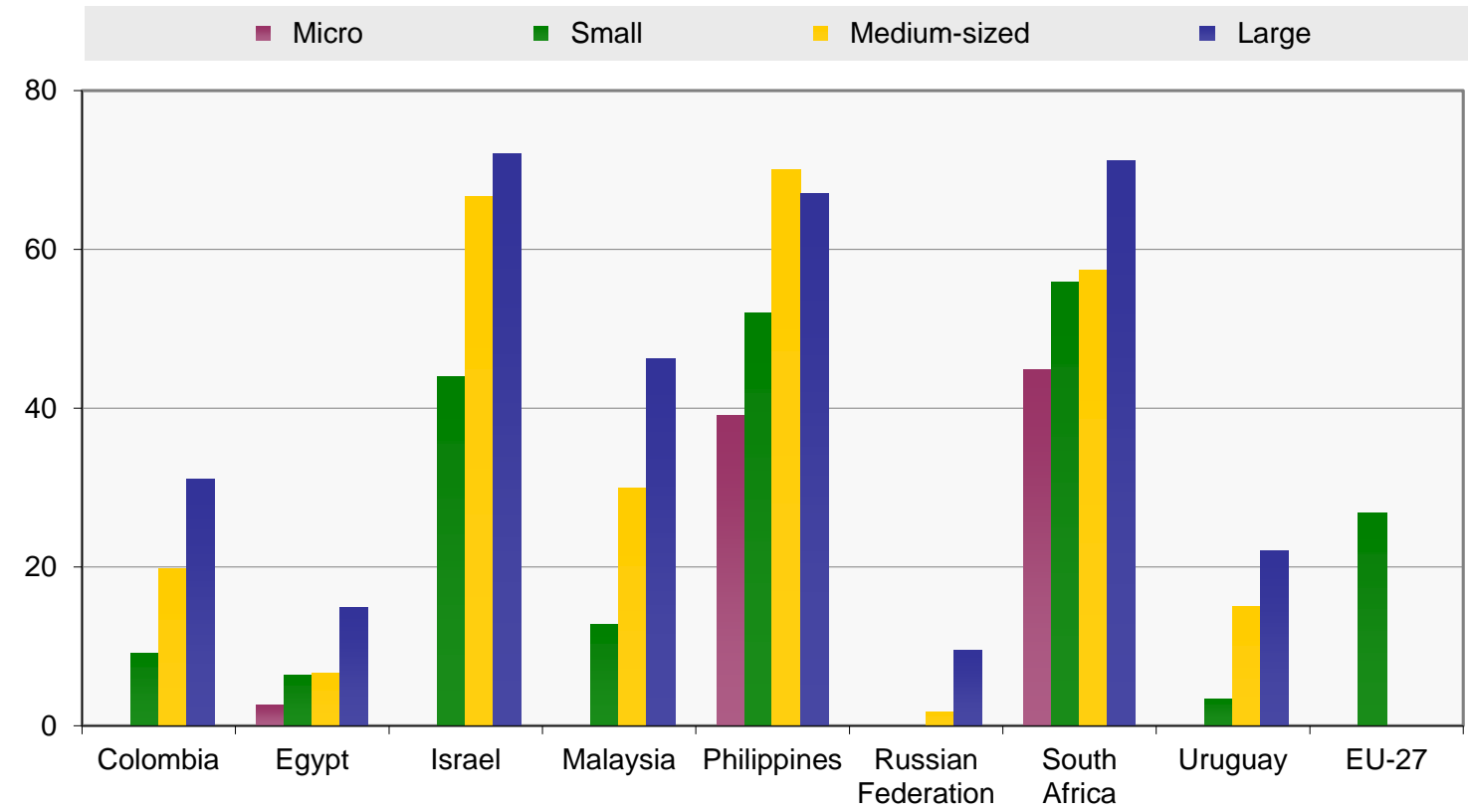

Notes: Based on a three-year observation period, except for the Russian Federation (1 year), the Philippines (1.5 years), Colombia (2 years), and Malaysia (4 years).

For Colombia: Sample survey data (no grossed up results).

For the Philippines: IT services are also included. Results are not representative of the target population.

For Egypt, Malaysia, the Philippines and South Africa: Organizational innovation includes new or significant changes.

Size classes are detailed in Annex II.

Source: 2011 UIS pilot data collection of innovation statistics and CIS 2008 database (Eurostat, 2012). 


\section{Marketing innovation}

New marketing practices can play a central role in a firm's performance and the success of its new products. In addition, market research and contacts with customers can play a crucial role in product and process development through demand-led innovation. Considerable resources are often allocated to market research and the development of new marketing practices, such as targeting new markets or market segments and developing new ways of promoting products. (Oslo Manual §12-14). The third edition of the Oslo Manual formally introduced the concept of marketing innovation.

\section{Definition}

Marketing innovation is the implementation of a new marketing method involving significant changes in product design or packaging, product placement, product promotion, or pricing (Oslo Manual §169). Firms that implemented at least one marketing innovation are marketing innovators.

Figure 7 shows the percentage of manufacturing firms that implement marketing innovation.

Figure 7. Manufacturing firms that implement marketing innovation as a percentage of all manufacturing firms

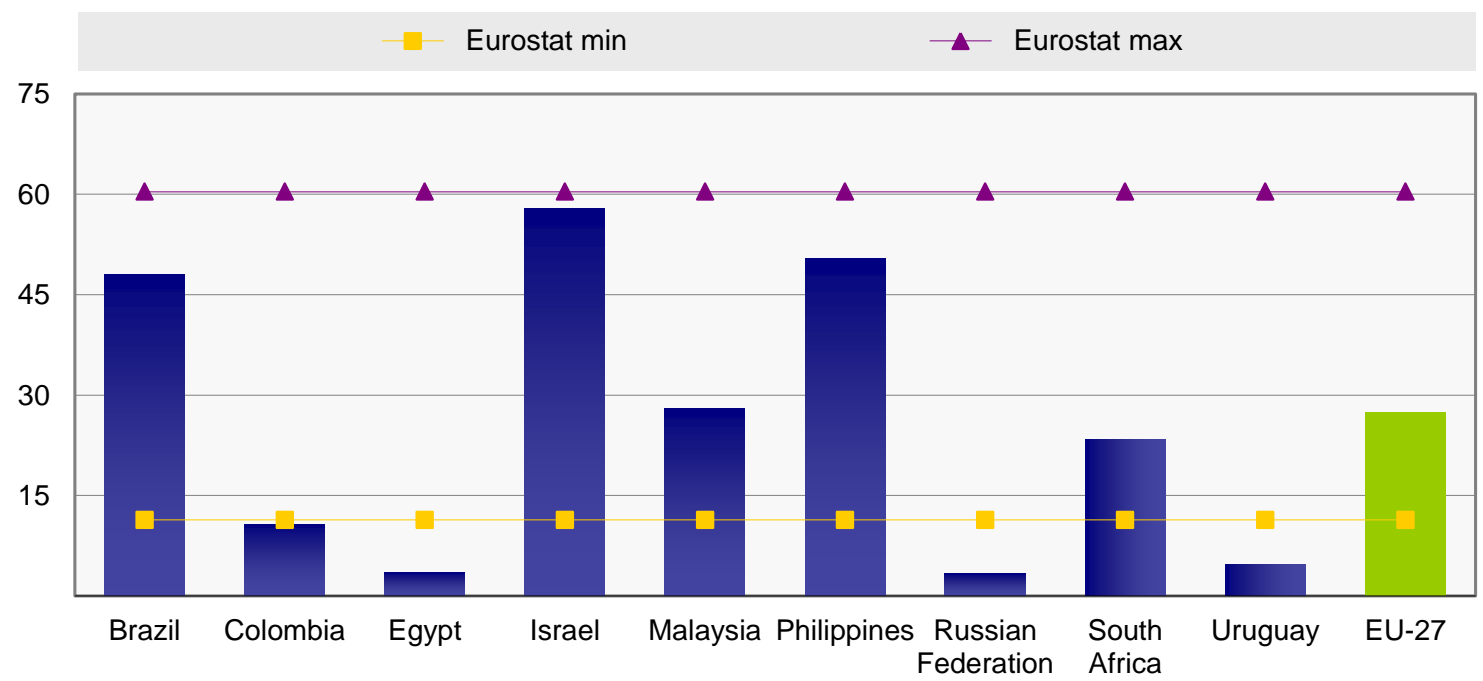

Notes: Based on a three-year observation period, except for the Russian Federation (1 year), the Philippines (1.5 years), Colombia (2 years), and Malaysia (4 years).

For Colombia: Sample survey data (no grossed up results).

For the Philippines: IT services are also included. Results are not representative of the target population.

For Colombia, Egypt, Malaysia and South Africa: Significant changes other than in design or packaging are also included.

Source: 2011 UIS pilot data collection of innovation statistics and CIS 2008 database (Eurostat, 2012). 
Of the responding countries, none exceed the Eurostat maximum $(60.4 \%)$ in its share of manufacturing firms that implement marketing innovation. The highest share is found in Israel (57.9\%), followed by the Philippines (50.4\%) and Brazil (48.0\%).

Malaysia (28.0\%) has approximately the same percentage of manufacturing firms that implement marking innovation as the EU average (27.5\%). In contrast, rates are considerably lower in Colombia (10.8\%), Uruguay (4.8\%), Egypt (3.6\%) and the Russian Federation (3.4\%).

Figure 8 shows the percentage of manufacturing firms that implement marketing innovation according to their size: micro, small, medium-sized or large.

While the EU has an average of $43.9 \%$ of large manufacturing firms which implement marketing innovation, large firms in four countries of the pilot data collection exceed this average: Israel (73.0\%), the Philippines (53.0\%), South Africa (48.9\%), and Malaysia (45.7\%).

Figure 8. Manufacturing firms that implement marketing innovation by size class as a percentage of manufacturing firms in each size class

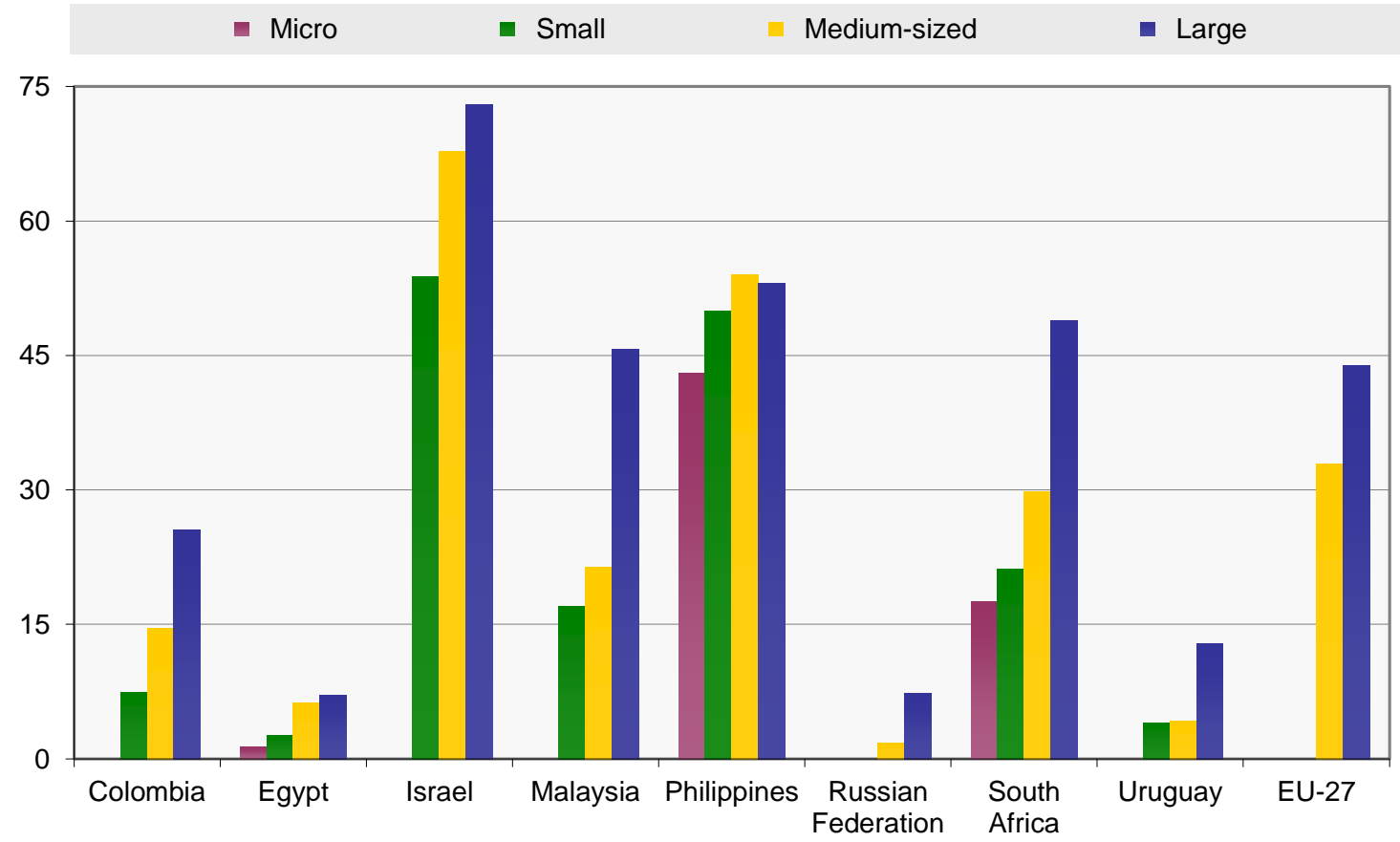

Notes: Based on a three-year observation period, except for the Russian Federation (1 year), the Philippines (1.5 years), Colombia (2 years), and Malaysia (4 years).

For Colombia: Sample survey data (no grossed up results).

For the Philippines: IT services are also included. Results are not representative of the target population.

For Colombia, Egypt, Malaysia and South Africa: Significant changes other than in design or packaging are also included.

Size classes are detailed in Annex II.

Source: UIS 2011 pilot data collection of innovation statistics and CIS 2008 database (Eurostat, 2012). 
Again, larger firms tend to have higher shares of innovators. The exception is the Philippines, where medium-sized manufacturing firms present the highest percentage of firms that implemented marketing innovation (54.0\%).

It is interesting to note that less than $15 \%$ of manufacturing firms, regardless of their size, implemented this type of innovation in Egypt, the Russian Federation and Uruguay. In Colombia, this is the case for small $(7.4 \%)$ and medium-sized $(14.6 \%)$ manufacturing firms.

\section{Box 6. Marketing innovation in Israel}

Of the responding countries, Israel has the highest share of manufacturing firms that implement marketing innovation in all size classes. At $73.0 \%$, large manufacturing firms in Israel far surpass the implementation of this type of innovation in any other responding country. The same is reported for medium-sized firms $(67.7 \%)$. The percentages of medium-sized and large manufacturing firms that implement marketing innovation in Israel are even higher than the Eurostat maximum for these size classes: $59.6 \%$ and $69.8 \%$ respectively. 


\section{Final remarks}

The 2011 UIS Pilot Data Collection of Innovation Statistics covers national aggregate data from 12 countries across different regions and at different levels of development. This pilot exercise represents a crucial step in the development of a global data collection of innovation statistics, which will be undertaken by the Institute in 2013 .

The production of cross-nationally comparable data on innovation is not an easy task, especially for developing countries. Questions, industrial coverage, size of firms, cut-off point and classification, sample selection and observation period are some of the characteristics that present dissimilarities and hence make comparisons hard. Therefore, caution is required when making comparisons and drafting conclusions and policy recommendations based solely on the results of this pilot. However, it is possible to identify some key findings.

First, all responding countries have manufacturing firms that implement innovation. This was observed for all types of innovation and in firms of different sizes. This complies with the assertion that innovation is widespread and pervasive and not restricted to wealthy countries or firms.

Second, larger firms have higher shares of innovators. The data show that higher percentages of large and medium-sized manufacturing firms implement innovations compared to small or micro manufacturing firms. This pattern applied to all types of innovation. In short, innovation is clearly linked to the size of the firm.

Third, in terms of innovation activity, most innovation-active manufacturing firms are engaged in the acquisition of machinery, equipment and software. The second most frequent type of innovation activity is training. In contrast, firms are least likely to be engaged in extramural R\&D and the acquisition of other external knowledge. These findings support the importance of the acquisition of embodied technology (equipment) in the innovation process, especially in developing countries.

Evidence also shows that most innovation-active manufacturing firms have relatively little interaction with universities or public research institutes when looking for information sources or cooperation partners. Instead, most firms rely on internal sources for information. They also tend to establish cooperation partnerships with either suppliers or clients.

Finally, it is worth highlighting the obstacles faced by innovation-active manufacturing firms. Within cost and economic factors, a lack of funds within the enterprise or enterprise group is rated as a highly important barrier by the majority of firms in most countries. Moreover, in the majority of countries, the shortage of qualified personnel and market domination by established enterprises are rated as highly important knowledge and market hampering factors, respectively. 


\section{Annex I. Tables}

Table A1. Manufacturing firms that implement product innovation, process innovation and product or process innovation as a percentage of all manufacturing firms

\begin{tabular}{lccc}
\hline & $\begin{array}{c}\text { Product } \\
\text { innovators } \\
\text { in manufacturing }\end{array}$ & $\begin{array}{c}\text { Process } \\
\text { innovators } \\
\text { in manufacturing }\end{array}$ & $\begin{array}{c}\text { Product or process } \\
\text { innovators }\end{array}$ \\
Brazil & 23.0 & 32.0 & 38.0 \\
China & 25.1 & 25.3 & 30.0 \\
Colombia & 4.6 & 20.0 & n.a. \\
Egypt & 6.0 & 8.3 & 9.3 \\
Ghana & n.a. & n.a. & n.a. \\
Indonesia & n.a. & n.a. & n.a. \\
Israel & 34.2 & 30.9 & 42.4 \\
Malaysia & 29.5 & 33.3 & 39.0 \\
Philippines & 38.0 & 44.0 & 50.2 \\
Russian Federation & 8.0 & 5.9 & 11.3 \\
South Africa & 16.8 & 13.1 & 20.9 \\
Uruguay & 17.2 & 24.5 & 28.6 \\
EU-27 & n.a. & n.a. & 42.0 \\
\hline Eurostat min & n.a. & n.a. & 15.0 \\
Eurostat max & n.a. & n.a. & 71.2 \\
\hline
\end{tabular}

Notes: Based on a three-year observation period, except for the Russian Federation (1 year), the Philippines (1.5 years), Colombia (2 years), and Malaysia (4 years).

For China: Product innovation covers only new or significantly improved goods. Logistics, delivery or distribution methods are not explicitly mentioned in process innovation.

For Colombia: Sample survey data (no grossed up results).

For the Philippines: IT services are also included. Results are not representative of the target population.

For EU-27/Eurostat: Data cover firms with abandoned or ongoing activities.

Source: 2011 UIS pilot data collection of innovation statistics and CIS 2006 database (Eurostat, 2012). 
Table A2. Manufacturing firms that implement product innovation by size class as a percentage of manufacturing firms in each size class

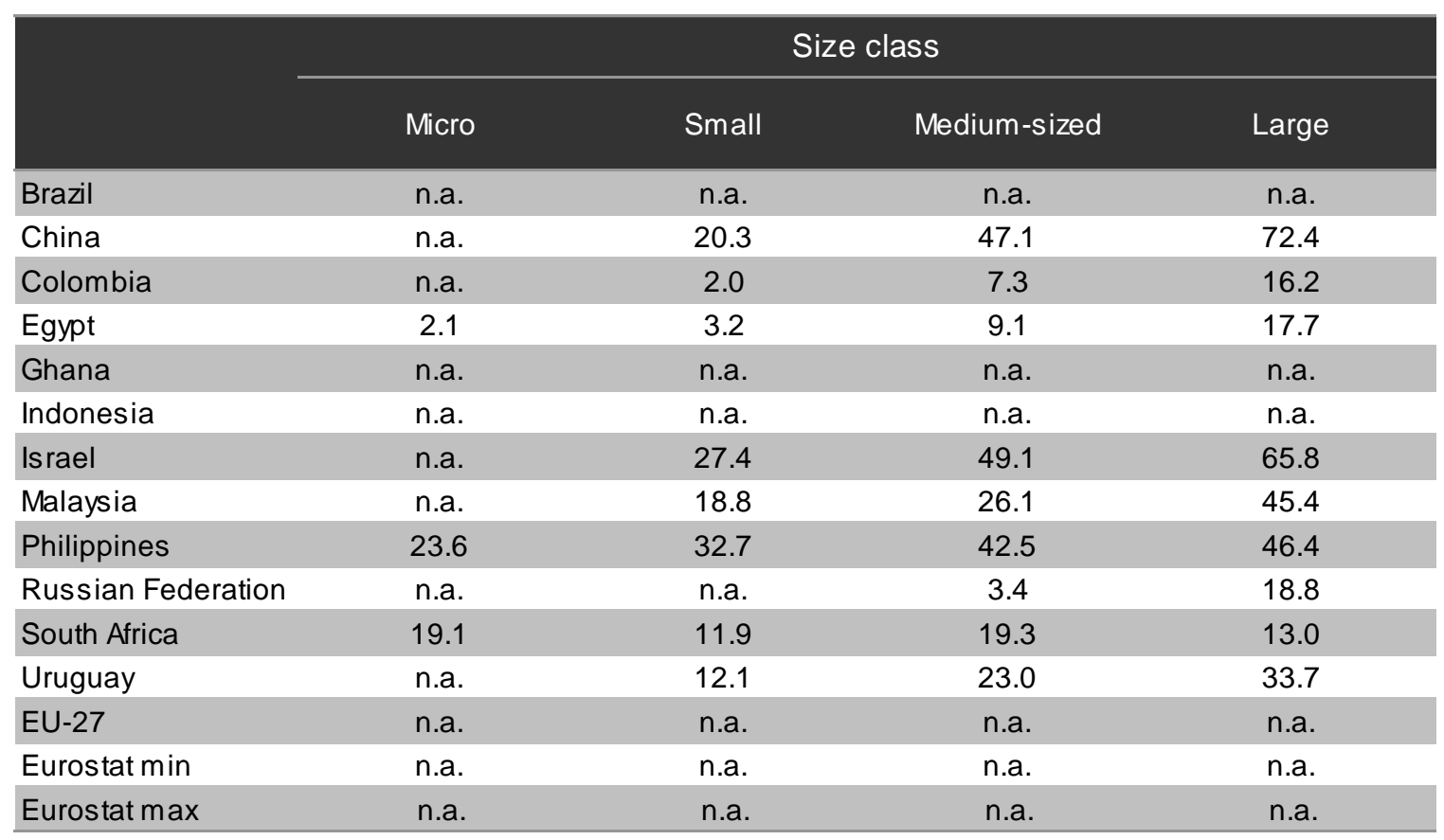

Notes: Based on a three-year observation period, except for the Russian Federation (1 year), the Philippines (1.5 years), Colombia (2 years), and Malaysia (4 years).

For China: Product innovation covers only new or significantly improved goods. Data broken down by size class cover manufacturing, mining and quarrying, and electricity, gas and water supply.

For Colombia: Sample survey data (no grossed up results).

For the Philippines: IT services are also included. Results are not representative of the target population.

Size classes are detailed in Annex II.

Source: 2011 UIS pilot data collection of innovation statistics. 
Table A3. Manufacturing firms that implement process innovation by size class as a percentage of manufacturing firms in each size class

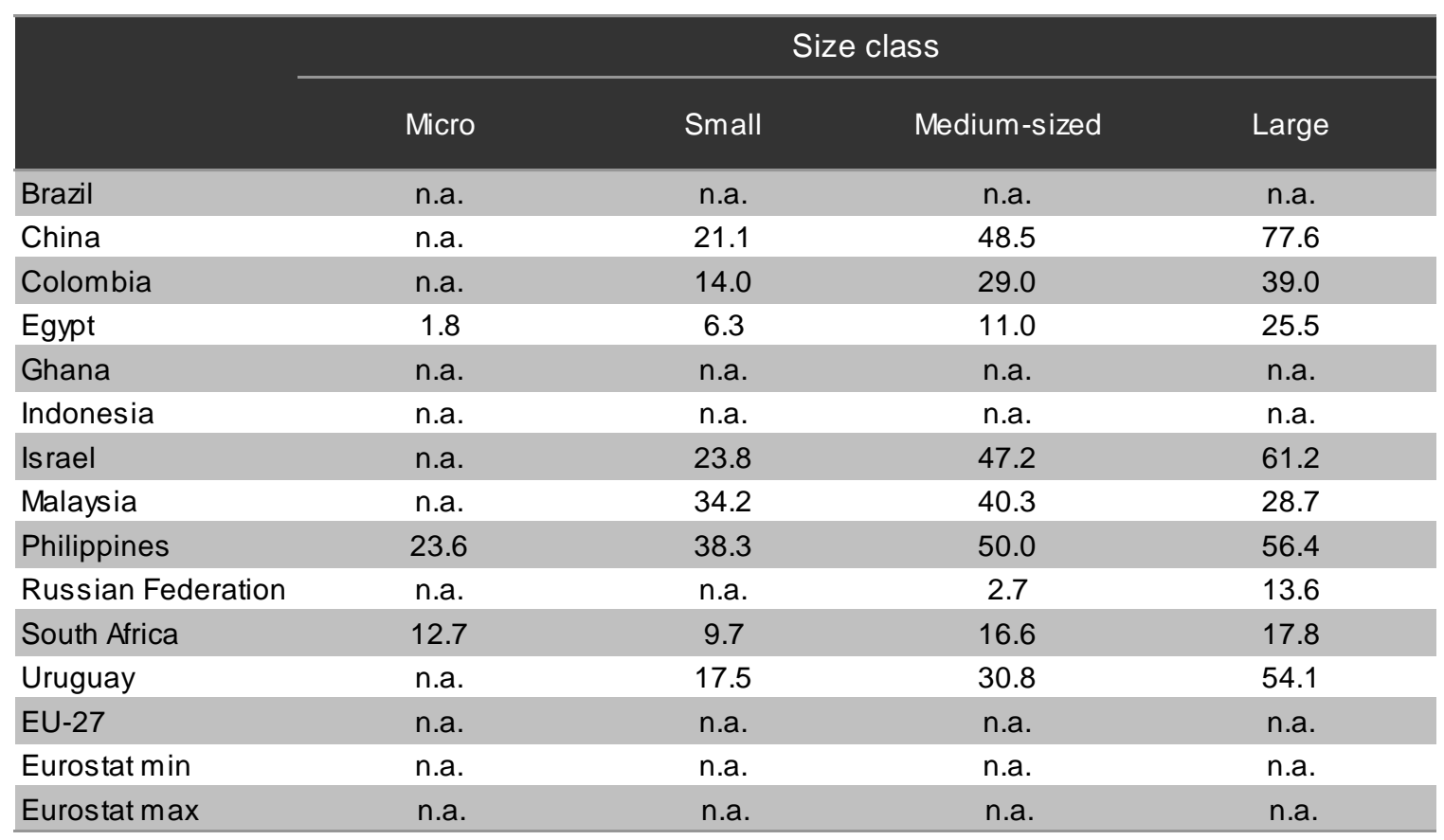

Notes: Based on a three-year observation period, except for the Russian Federation (1 year), the Philippines (1.5 years), Colombia (2 years), and Malaysia (4 years).

For China: Logistics, delivery or distribution methods are not explicitly mentioned in process innovation. Data broken down by size class cover manufacturing, mining and quarrying, and electricity, gas and water supply.

For Colombia: Sample survey data (no grossed up results).

For the Philippines: IT services are also included. Results are not representative of the target population.

Size classes are detailed in Annex II.

Source: 2011 UIS pilot data collection of innovation statistics. 
Table A4. Manufacturing firms that implement product or process innovation by size class as a percentage of manufacturing firms in each size class

\begin{tabular}{lcccc} 
& \multicolumn{3}{c}{ Size class } \\
\cline { 2 - 4 } & Micro & Small & Medium-sized & Large \\
\hline Brazil & n.a. & n.a. & n.a. & n.a. \\
China & n.a. & 25.2 & 55.9 & 83.5 \\
Colombia & n.a. & 14.6 & 30.6 & 45.0 \\
Egypt & n.a. & n.a. & n.a. & n.a. \\
Ghana & n.a. & n.a. & n.a. & n.a. \\
Indonesia & n.a. & n.a. & n.a. & n.a. \\
Israel & n.a. & 35.7 & 57.3 & 75.5 \\
Malaysia & n.a. & 42.1 & 47.9 & n.a. \\
Philippines & 30.2 & 45.8 & 58.8 & 60.8 \\
Russian Federation & n.a. & n.a. & 5.4 & 25.4 \\
South Africa & 20.4 & 17.4 & 25.6 & 20.5 \\
\hline Uruguay & n.a. & n.a. & n.a. & n.a. \\
EU-27 & n.a. & 35.5 & n.a. & n.a. \\
\hline Eurostat min & n.a. & 10.3 & 25.4 & 41.0 \\
\hline Eurostat max & n.a. & 65.1 & 76.4 & 91.4 \\
\hline
\end{tabular}

Notes: Based on a three-year observation period, except for the Russian Federation (1 year), the Philippines (1.5 years), Colombia (2 years), and Malaysia (4 years).

For China: Product innovation covers only new or significantly improved goods. Logistics, delivery or distribution methods are not explicitly mentioned in process innovation. Data broken down by size class cover manufacturing, mining and quarrying, and electricity, gas and water supply.

For Colombia: Sample survey data (no grossed up results).

For the Philippines: IT services are also included. Results are not representative of the target population.

For EU-27/Eurostat: Data cover firms with abandoned or ongoing activities.

Size classes are detailed in Annex II.

Source: 2011 UIS pilot data collection of innovation statistics and CIS 2006 database (Eurostat, 2012). 
Table A5. Manufacturing firms that implement product innovation by economic activity (ISIC Rev. 3.1 division level) as a percentage of manufacturing firms in each economic activity

\begin{tabular}{|c|c|c|c|c|c|c|c|c|c|c|c|c|c|c|c|}
\hline & & & & & & & & Country & & & & & & & \\
\hline & Brazil & China & Colombia & Egypt & Ghana & Indonesia & Israel & Malaysia & Philippines & $\begin{array}{c}\text { Russian } \\
\text { Federation }\end{array}$ & $\begin{array}{l}\text { South } \\
\text { Africa }\end{array}$ & Uruguay & EU-27 & $\begin{array}{c}\text { Eurostat } \\
\text { min }\end{array}$ & $\begin{array}{l}\text { Eurostat } \\
\text { max }\end{array}$ \\
\hline Manufacturing & 23.0 & 25.1 & 4.6 & 6.0 & n.a. & n.a. & 34.2 & 29.5 & 38.0 & 8.0 & 16.8 & n.a. & n.a. & n.a. & n.a. \\
\hline $\begin{array}{l}\text { Food products and } \\
\text { beverages }\end{array}$ & 25.0 & n.a. & 2.8 & n.a. & 12.6 & 49.5 & 31.1 & n.a. & 33.5 & n.a. & n.a. & n.a. & n.a. & n.a. & n.a. \\
\hline Tobacco products & 19.6 & n.a. & 16.7 & n.a. & n.a. & 41.9 & n.a. & n.a. & n.a. & n.a. & n.a. & n.a. & n.a. & n.a. & n.a. \\
\hline Textiles & 25.1 & n.a. & 6.6 & n.a. & 4.6 & 61.6 & 20.9 & n.a. & n.a. & n.a. & n.a. & n.a. & n.a. & n.a. & n.a. \\
\hline Wearing apparel and fur & 19.3 & n.a. & 2.5 & n.a. & 1.1 & 69.5 & 13.5 & n.a. & n.a. & n.a. & n.a. & n.a. & n.a. & n.a. & n.a. \\
\hline $\begin{array}{l}\text { Leather products and } \\
\text { footwear }\end{array}$ & 24.4 & n.a. & 3.1 & n.a. & n.a. & 82.8 & 40.9 & n.a. & n.a. & n.a. & n.a. & n.a. & n.a. & n.a. & n.a. \\
\hline $\begin{array}{l}\text { Wood and cork (not } \\
\text { furniture) }\end{array}$ & 13.1 & n.a. & 1.3 & n.a. & 12.6 & 71.7 & 40.9 & n.a. & n.a. & n.a. & n.a. & n.a. & n.a. & n.a. & n.a. \\
\hline $\begin{array}{l}\text { Pulp, paper \& paper } \\
\text { production }\end{array}$ & 25.5 & n.a. & 5.4 & n.a. & 2.3 & 50.0 & 28.1 & n.a. & n.a. & n.a. & n.a. & n.a. & n.a. & n.a. & n.a. \\
\hline $\begin{array}{l}\text { Publishing, printing and } \\
\text { reproduction of recorded } \\
\text { media }\end{array}$ & 20.7 & n.a. & 2.5 & n.a. & 2.3 & 73.3 & 33.1 & n.a. & n.a. & n.a. & n.a. & n.a. & n.a. & n.a. & n.a. \\
\hline $\begin{array}{l}\text { Coke, refined petroleum } \\
\text { products and nuclear fuel }\end{array}$ & 15.2 & n.a. & 3.0 & n.a. & 1.2 & 50.0 & 6.9 & n.a. & n.a. & n.a. & n.a. & n.a. & n.a. & n.a. & n.a. \\
\hline $\begin{array}{l}\text { Chemicals and chemical } \\
\text { products }\end{array}$ & 46.6 & n.a. & 8.0 & n.a. & 11.5 & 57.6 & 58.1 & n.a. & n.a. & n.a. & n.a. & n.a. & n.a. & n.a. & n.a. \\
\hline $\begin{array}{l}\text { Rubber and plastic } \\
\text { products }\end{array}$ & 25.9 & n.a. & 5.9 & n.a. & 5.7 & 60.0 & 36.2 & n.a. & n.a. & n.a. & n.a. & n.a. & n.a. & n.a. & n.a. \\
\hline $\begin{array}{l}\text { Non-metallic mineral } \\
\text { products }\end{array}$ & 14.3 & n.a. & 4.8 & n.a. & 2.3 & 55.8 & 32.4 & n.a. & n.a. & n.a. & n.a. & n.a. & n.a. & n.a. & n.a. \\
\hline Basic metals & 20.5 & n.a. & 4.2 & n.a. & 3.5 & 50.0 & 36.0 & n.a. & n.a. & n.a. & n.a. & n.a. & n.a. & n.a. & n.a. \\
\hline
\end{tabular}


Table A5. Manufacturing firms that implement product innovation by economic activity (ISIC Rev. 3.1 division level) as a percentage of manufacturing firms in each economic activity (cont.)

\begin{tabular}{|c|c|c|c|c|c|c|c|c|c|c|c|c|c|c|c|}
\hline & \multicolumn{15}{|c|}{ Country } \\
\hline & Brazil & China & Colombia & Egypt & Ghana & Indonesia & Israel & Malaysia & Philippines & $\begin{array}{l}\text { Russian } \\
\text { Federation }\end{array}$ & $\begin{array}{l}\text { South } \\
\text { Africa }\end{array}$ & Uruguay & EU-27 & $\begin{array}{c}\text { Eurostat } \\
\text { min }\end{array}$ & $\begin{array}{c}\text { Eurostat } \\
\max \end{array}$ \\
\hline $\begin{array}{l}\text { Fabricated metal } \\
\text { products (exc. mach. and } \\
\text { equipm.) }\end{array}$ & 19.2 & n.a. & 3.5 & n.a. & 11.5 & 66.7 & 28.5 & n.a. & n.a. & n.a. & n.a. & n.a. & n.a. & n.a. & n.a. \\
\hline Machinery n.e.c. & 28.4 & n.a. & 6.7 & n.a. & n.a. & 80.0 & 45.8 & n.a. & n.a. & n.a. & n.a. & n.a. & n.a. & n.a. & n.a. \\
\hline $\begin{array}{l}\text { Office, accounting and } \\
\text { computing machinery }\end{array}$ & 34.3 & n.a. & n.a. & n.a. & n.a. & 0.0 & n.a. & n.a. & n.a. & n.a. & n.a. & n.a. & n.a. & n.a. & n.a. \\
\hline Electrical machinery & 32.3 & n.a. & 12.6 & n.a. & n.a. & 37.5 & 35.8 & n.a. & n.a. & n.a. & n.a. & n.a. & n.a. & n.a. & n.a. \\
\hline $\begin{array}{l}\text { Electronic equipment } \\
\text { (radio, TV \& comm.) }\end{array}$ & 41.9 & n.a. & 10.5 & n.a. & n.a. & 42.9 & 56.2 & n.a. & 50.0 & n.a. & n.a. & n.a. & n.a. & n.a. & n.a. \\
\hline $\begin{array}{l}\text { Medical, precision and } \\
\text { optical instruments, } \\
\text { watches, clocks (instr.) }\end{array}$ & 39.7 & n.a. & 12.5 & n.a. & n.a. & 100.0 & 63.4 & n.a. & n.a. & n.a. & n.a. & n.a. & n.a. & n.a. & n.a. \\
\hline Motor vehicles & 29.7 & n.a. & 4.7 & n.a. & n.a. & 62.5 & 6.3 & n.a. & n.a. & n.a. & n.a. & n.a. & n.a. & n.a. & n.a. \\
\hline $\begin{array}{l}\text { Other transport } \\
\text { equipment }\end{array}$ & 12.0 & n.a. & 8.7 & n.a. & n.a. & 83.3 & 27.8 & n.a. & n.a. & n.a. & n.a. & n.a. & n.a. & n.a. & n.a. \\
\hline $\begin{array}{l}\text { Furniture, other } \\
\text { manufacturing n.e.c. }\end{array}$ & 20.6 & n.a. & 4.5 & n.a. & 5.8 & 84.2 & 36.9 & n.a. & n.a. & n.a. & n.a. & n.a. & n.a. & n.a. & n.a. \\
\hline Recycling & 3.5 & n.a. & n.a. & n.a. & n.a. & 100.0 & n.a. & n.a. & n.a. & n.a. & n.a. & n.a. & n.a. & n.a. & n.a. \\
\hline
\end{tabular}

Notes: Based on a three-year observation period, except for the Russian Federation (1 year), the Philippines (1.5 years), Colombia (2 years), Indonesia (2 years), and Malaysia (4 years).

For China: Product innovation covers only new or significantly improved goods.

For Colombia: Sample survey data (no grossed up results).

For Indonesia: The target population was medium-sized and large firms that implemented any type of innovation.

For the Philippines: IT services are also included. Results are not representative of the target population.

Source: 2011 UIS pilot data collection of innovation statistics. 
Table A6. Manufacturing firms that implement process innovation by economic activity (ISIC Rev. 3.1 division level) as a percentage of manufacturing firms in each economic activity

\begin{tabular}{|c|c|c|c|c|c|c|c|c|c|c|c|c|c|c|c|}
\hline & \multicolumn{15}{|c|}{ Country } \\
\hline & Brazil & China & Colombia & Egypt & Ghana & Indonesia & Israel & Malaysia & Philippines & $\begin{array}{l}\text { Russian } \\
\text { Federation }\end{array}$ & $\begin{array}{l}\text { South } \\
\text { Africa }\end{array}$ & Uruguay & EU-27 & $\begin{array}{c}\text { Eurostat } \\
\text { min }\end{array}$ & $\begin{array}{c}\text { Eurostat } \\
\max \end{array}$ \\
\hline Manufacturing & 32.0 & 25.3 & 20.0 & 8.3 & n.a. & n.a. & 30.9 & 33.3 & 44.0 & 5.9 & 13.1 & n.a. & n.a. & n.a. & n.a. \\
\hline $\begin{array}{l}\text { Food products and } \\
\text { beverages }\end{array}$ & 31.0 & n.a. & 23.5 & n.a. & 8.1 & 48.1 & 39.3 & n.a. & 37.2 & n.a. & n.a. & n.a. & n.a. & n.a. & n.a. \\
\hline Tobacco products & 17.7 & n.a. & 33.3 & n.a. & n.a. & 46.5 & n.a. & n.a. & n.a. & n.a. & n.a. & n.a. & n.a. & n.a. & n.a. \\
\hline Textiles & 31.7 & n.a. & 17.3 & n.a. & 3.4 & 59.3 & 22.6 & n.a. & n.a. & n.a. & n.a. & n.a. & n.a. & n.a. & n.a. \\
\hline Wearing apparel and fur & 32.8 & n.a. & 14.6 & n.a. & 1.1 & 41.5 & 9.3 & n.a. & n.a. & n.a. & n.a. & n.a. & n.a. & n.a. & n.a. \\
\hline $\begin{array}{l}\text { Leather products and } \\
\text { footwear }\end{array}$ & 32.5 & n.a. & 11.8 & n.a. & n.a. & 41.4 & 27.3 & n.a. & n.a. & n.a. & n.a. & n.a. & n.a. & n.a. & n.a. \\
\hline $\begin{array}{l}\text { Wood and cork (not } \\
\text { furniture) }\end{array}$ & 19.7 & n.a. & 16.1 & n.a. & 12.6 & 60.9 & 33.5 & n.a. & n.a. & n.a. & n.a. & n.a. & n.a. & n.a. & n.a. \\
\hline $\begin{array}{l}\text { Pulp, paper \& paper } \\
\text { production }\end{array}$ & 34.0 & n.a. & 31.1 & n.a. & 1.2 & 50.0 & 28.1 & n.a. & n.a. & n.a. & n.a. & n.a. & n.a. & n.a. & n.a. \\
\hline $\begin{array}{l}\text { Publishing, printing and } \\
\text { reproduction of recorded } \\
\text { media }\end{array}$ & 38.4 & n.a. & 14.2 & n.a. & 1.2 & 70.0 & 22.4 & n.a. & n.a. & n.a. & n.a. & n.a. & n.a. & n.a. & n.a. \\
\hline $\begin{array}{l}\text { Coke, refined petroleum } \\
\text { products and nuclear fuel }\end{array}$ & 38.4 & n.a. & 18.2 & n.a. & 1.2 & 50.0 & 6.9 & n.a. & n.a. & n.a. & n.a. & n.a. & n.a. & n.a. & n.a. \\
\hline $\begin{array}{l}\text { Chemicals and chemical } \\
\text { products }\end{array}$ & 47.3 & n.a. & 22.3 & n.a. & 6.9 & 51.5 & 32.0 & n.a. & n.a. & n.a. & n.a. & n.a. & n.a. & n.a. & n.a. \\
\hline $\begin{array}{l}\text { Rubber and plastic } \\
\text { products }\end{array}$ & 29.1 & n.a. & 20.5 & n.a. & 5.7 & 64.4 & 23.5 & n.a. & n.a. & n.a. & n.a. & n.a. & n.a. & n.a. & n.a. \\
\hline $\begin{array}{l}\text { Non-metallic mineral } \\
\text { products }\end{array}$ & 28.6 & n.a. & 20.2 & n.a. & 2.3 & 60.5 & 32.9 & n.a. & n.a. & n.a. & n.a. & n.a. & n.a. & n.a. & n.a. \\
\hline Basic metals & 32.6 & n.a. & 21.1 & n.a. & 2.3 & 100.0 & 30.4 & n.a. & n.a. & n.a. & n.a. & n.a. & n.a. & n.a. & n.a. \\
\hline
\end{tabular}


Table A6. Manufacturing firms that implement process innovation by economic activity (ISIC Rev. 3.1 division level) as a percentage of manufacturing firms in each economic activity (cont.)

\begin{tabular}{|c|c|c|c|c|c|c|c|c|c|c|c|c|c|c|c|}
\hline & \multicolumn{15}{|c|}{ Country } \\
\hline & Brazil & China & Colombia & Egypt & Ghana & Indonesia & Israel & Malaysia & Philippines & $\begin{array}{l}\text { Russian } \\
\text { Federation }\end{array}$ & $\begin{array}{l}\text { South } \\
\text { Africa }\end{array}$ & Uruguay & EU-27 & $\begin{array}{c}\text { Eurostat } \\
\text { min }\end{array}$ & $\begin{array}{c}\text { Eurostat } \\
\max \end{array}$ \\
\hline $\begin{array}{l}\text { Fabricated metal } \\
\text { products (exc. mach. and } \\
\text { equipm.) }\end{array}$ & 34.5 & n.a. & 18.1 & n.a. & 11.5 & 66.7 & 36.4 & n.a. & n.a. & n.a. & n.a. & n.a. & n.a. & n.a. & n.a. \\
\hline Machinery n.e.c. & 34.2 & n.a. & 18.4 & n.a. & n.a. & 53.3 & 22.5 & n.a. & n.a. & n.a. & n.a. & n.a. & n.a. & n.a. & n.a. \\
\hline $\begin{array}{l}\text { Office, accounting and } \\
\text { computing machinery }\end{array}$ & 45.0 & n.a. & n.a. & n.a. & n.a. & 100.0 & n.a. & n.a. & n.a. & n.a. & n.a. & n.a. & n.a. & n.a. & n.a. \\
\hline Electrical machinery & 35.1 & n.a. & 27.7 & n.a. & n.a. & 87.5 & 34.6 & n.a. & n.a. & n.a. & n.a. & n.a. & n.a. & n.a. & n.a. \\
\hline $\begin{array}{l}\text { Electronic equipment } \\
\text { (radio, TV \& comm.) }\end{array}$ & 34.1 & n.a. & 15.8 & n.a. & n.a. & 57.1 & 43.5 & n.a. & 55.0 & n.a. & n.a. & n.a. & n.a. & n.a. & n.a. \\
\hline $\begin{array}{l}\text { Medical, precision and } \\
\text { optical instruments, } \\
\text { watches, clocks (instr.) }\end{array}$ & 37.2 & n.a. & 17.2 & n.a. & n.a. & 100.0 & 44.8 & n.a. & n.a. & n.a. & n.a. & n.a. & n.a. & n.a. & n.a. \\
\hline Motor vehicles & 35.9 & n.a. & 18.3 & n.a. & n.a. & 87.5 & 4.7 & n.a. & n.a. & n.a. & n.a. & n.a. & n.a. & n.a. & n.a. \\
\hline $\begin{array}{l}\text { Other transport } \\
\text { equipment }\end{array}$ & 27.6 & n.a. & 13.0 & n.a. & n.a. & 75.0 & 30.1 & n.a. & n.a. & n.a. & n.a. & n.a. & n.a. & n.a. & n.a. \\
\hline $\begin{array}{l}\text { Furniture, other } \\
\text { manufacturing n.e.c. }\end{array}$ & 28.0 & n.a. & 19.9 & n.a. & 5.8 & 46.3 & 31.1 & n.a. & n.a. & n.a. & n.a. & n.a. & n.a. & n.a. & n.a. \\
\hline Recycling & 7.5 & n.a. & n.a. & n.a. & n.a. & 50.0 & n.a. & n.a. & n.a. & n.a. & n.a. & n.a. & n.a. & n.a. & n.a. \\
\hline
\end{tabular}

Notes: Based on a three-year observation period, except for the Russian Federation (1 year), the Philippines (1.5 years), Colombia (2 years), Indonesia (2 years), and Malaysia (4 years).

For China: Logistics, delivery or distribution methods are not explicitly mentioned in process innovation.

For Colombia: Sample survey data (no grossed up results).

For Indonesia: The target population was medium-sized and large firms that implemented any type of innovation.

For the Philippines: IT services are also included. Results are not representative of the target population.

Source: 2011 UIS pilot data collection of innovation statistics. 
Table A7. Manufacturing firms that implement product or process innovation by economic activity (ISIC Rev. 3.1 division level) as a percentage of manufacturing firms in each economic activity

\begin{tabular}{|c|c|c|c|c|c|c|c|c|c|c|c|c|c|c|c|}
\hline & & & & & & & & Country & & & & & & & \\
\hline & Brazil & China & Colombia & Egypt & Ghana & Indonesia & Israel & Malaysia & Philippines & $\begin{array}{c}\text { Russian } \\
\text { Federation }\end{array}$ & $\begin{array}{l}\text { South } \\
\text { Africa }\end{array}$ & Uruguay & EU-27 & $\begin{array}{c}\text { Eurostat } \\
\text { min }\end{array}$ & $\begin{array}{l}\text { Eurostat } \\
\text { max }\end{array}$ \\
\hline Manufacturing & 38.0 & 30.0 & n.a. & 9.3 & n.a. & n.a. & 42.4 & 39.0 & 50.2 & 11.3 & 20.9 & n.a. & 42.0 & 15.0 & 71.2 \\
\hline $\begin{array}{l}\text { Food products and } \\
\text { beverages }\end{array}$ & 38.0 & n.a. & 24.4 & n.a. & n.a. & 95.2 & 46.8 & n.a. & 44.0 & n.a. & n.a. & n.a. & n.a. & 19.5 & 64.0 \\
\hline Tobacco products & 26.5 & n.a. & 50.0 & n.a. & n.a. & 76.7 & n.a. & n.a. & n.a. & n.a. & n.a. & n.a. & n.a. & 32.1 & 90.9 \\
\hline Textiles & 37.6 & n.a. & 20.0 & n.a. & n.a. & 100.0 & 26.8 & n.a. & n.a. & n.a. & n.a. & n.a. & n.a. & 12.8 & 78.4 \\
\hline Wearing apparel and fur & 36.7 & n.a. & 15.3 & n.a. & n.a. & 100.0 & 16.4 & n.a. & n.a. & n.a. & n.a. & n.a. & n.a. & 3.8 & 54.6 \\
\hline $\begin{array}{l}\text { Leather products and } \\
\text { footwear }\end{array}$ & 36.8 & n.a. & 13.5 & n.a. & n.a. & 100.0 & 44.3 & n.a. & n.a. & n.a. & n.a. & n.a. & n.a. & 5.6 & 71.4 \\
\hline $\begin{array}{l}\text { Wood and cork (not } \\
\text { furniture) }\end{array}$ & 23.6 & n.a. & 16.8 & n.a. & n.a. & 100.0 & 44.6 & n.a. & n.a. & n.a. & n.a. & n.a. & n.a. & 12.7 & 100.0 \\
\hline $\begin{array}{l}\text { Pulp, paper \& paper } \\
\text { production }\end{array}$ & 35.2 & n.a. & 32.0 & n.a. & n.a. & 100.0 & 29.1 & n.a. & n.a. & n.a. & n.a. & n.a. & n.a. & 18.2 & 100.0 \\
\hline $\begin{array}{l}\text { Publishing, printing and } \\
\text { reproduction of recorded } \\
\text { media }\end{array}$ & 43.0 & n.a. & 15.5 & n.a. & n.a. & 100.0 & 34.8 & n.a. & n.a. & n.a. & n.a. & n.a. & n.a. & 4.6 & 69.6 \\
\hline $\begin{array}{l}\text { Coke, refined petroleum } \\
\text { products and nuclear fuel }\end{array}$ & 41.4 & n.a. & 21.2 & n.a. & n.a. & 100.0 & 6.9 & n.a. & n.a. & n.a. & n.a. & n.a. & n.a. & 17.2 & 76.9 \\
\hline $\begin{array}{l}\text { Chemicals and chemical } \\
\text { products }\end{array}$ & 62.0 & n.a. & 24.9 & n.a. & n.a. & 100.0 & 58.6 & n.a. & n.a. & n.a. & n.a. & n.a. & n.a. & 36.6 & 86.8 \\
\hline $\begin{array}{l}\text { Rubber and plastic } \\
\text { products }\end{array}$ & 36.3 & n.a. & 22.3 & n.a. & n.a. & 100.0 & 40.6 & n.a. & n.a. & n.a. & n.a. & n.a. & n.a. & 11.2 & 92.9 \\
\hline $\begin{array}{l}\text { Non-metallic mineral } \\
\text { products }\end{array}$ & 33.4 & n.a. & 22.3 & n.a. & n.a. & 100.0 & 39.0 & n.a. & n.a. & n.a. & n.a. & n.a. & n.a. & 19.9 & 80.0 \\
\hline Basic metals & 39.5 & n.a. & 23.2 & n.a. & n.a. & 100.0 & 48.2 & n.a. & n.a. & n.a. & n.a. & n.a. & n.a. & 28.3 & 90.7 \\
\hline
\end{tabular}


Table A7. Manufacturing firms that implement product or process innovation by economic activity (ISIC Rev. 3.1 division level) as a percentage of manufacturing firms in each economic activity (cont.)

\begin{tabular}{|c|c|c|c|c|c|c|c|c|c|c|c|c|c|c|c|}
\hline & & & & & & & & Country & & & & & & & \\
\hline & Brazil & China & Colombia & Egypt & Ghana & Indonesia & Israel & Malaysia & Philippines & $\begin{array}{l}\text { Russian } \\
\text { Federation }\end{array}$ & $\begin{array}{l}\text { South } \\
\text { Africa }\end{array}$ & Uruguay & EU-27 & $\begin{array}{c}\text { Eurostat } \\
\text { min }\end{array}$ & $\begin{array}{c}\text { Eurostat } \\
\max \end{array}$ \\
\hline $\begin{array}{l}\text { Fabricated metal } \\
\text { products (exc. mach. and } \\
\text { equipm.) }\end{array}$ & 39.2 & n.a. & 19.0 & n.a. & n.a. & 100.0 & 41.7 & n.a. & n.a. & n.a. & n.a. & n.a. & n.a. & 18.3 & 63.5 \\
\hline Machinery n.e.c. & 44.8 & n.a. & 21.2 & n.a. & n.a. & 100.0 & 45.8 & n.a. & n.a. & n.a. & n.a. & n.a. & 55.6 & 9.1 & 88.2 \\
\hline $\begin{array}{l}\text { Office, accounting and } \\
\text { computing machinery }\end{array}$ & 53.8 & n.a. & n.a. & n.a. & n.a. & 100.0 & n.a. & n.a. & n.a. & n.a. & n.a. & n.a. & n.a. & 24.2 & 100.0 \\
\hline Electrical machinery & 44.7 & n.a. & 32.1 & n.a. & n.a. & 100.0 & 53.1 & n.a. & n.a. & n.a. & n.a. & n.a. & n.a. & 23.3 & 81.2 \\
\hline $\begin{array}{l}\text { Electronic equipment } \\
\text { (radio, TV \& comm.) }\end{array}$ & 51.6 & n.a. & 21.1 & n.a. & n.a. & 100.0 & 60.6 & n.a. & 62.0 & n.a. & n.a. & n.a. & n.a. & 21.1 & 100.0 \\
\hline $\begin{array}{l}\text { Medical, precision and } \\
\text { optical instruments, } \\
\text { watches, clocks (instr.) }\end{array}$ & 51.2 & n.a. & 23.4 & n.a. & n.a. & 100.0 & 67.1 & n.a. & n.a. & n.a. & n.a. & n.a. & n.a. & 21.2 & 91.5 \\
\hline Motor vehicles & 44.3 & n.a. & 20.4 & n.a. & n.a. & 100.0 & 6.3 & n.a. & n.a. & n.a. & n.a. & n.a. & n.a. & 22.7 & 82.0 \\
\hline $\begin{array}{l}\text { Other transport } \\
\text { equipment }\end{array}$ & 29.8 & n.a. & 17.4 & n.a. & n.a. & 100.0 & 30.1 & n.a. & n.a. & n.a. & n.a. & n.a. & n.a. & n.a. & n.a. \\
\hline $\begin{array}{l}\text { Furniture, other } \\
\text { manufacturing n.e.c. }\end{array}$ & 32.6 & n.a. & 20.8 & n.a. & n.a. & 100.0 & 51.3 & n.a. & n.a. & n.a. & n.a. & n.a. & n.a. & 19.2 & 65.3 \\
\hline Recycling & 9.0 & n.a. & n.a. & n.a. & n.a. & 100.0 & n.a. & n.a. & n.a. & n.a. & n.a. & n.a. & n.a. & 0.0 & 100.0 \\
\hline
\end{tabular}

Notes: Based on a three-year observation period, except for the Russian Federation (1 year), the Philippines (1.5 years), Colombia (2 years), Indonesia (2 years), and Malaysia (4 years).

For China: Product innovation covers only new or significantly improved goods. Logistics, delivery or distribution methods are not explicitly mentioned in process innovation.

For Colombia: Sample survey data (no grossed up results)

For Indonesia: The target population was medium-sized and large firms that implemented any type of innovation.

For the Philippines: IT services are also included. Results are not representative of the target population.

For EU-27/Eurostat: Data cover firms with abandoned or ongoing activities.

Source: 2011 UIS pilot data collection of innovation statistics and CIS 2006 database (Eurostat, 2012). 
Table A8. Other highly important hampering factors for firms as a percentage of innovation-active manufacturing firms

\begin{tabular}{|c|c|c|c|}
\hline & \multicolumn{3}{|c|}{ Other factors } \\
\hline & $\begin{array}{c}\text { Organisational rigidities } \\
\text { within the enterprise }\end{array}$ & $\begin{array}{l}\text { Insufficient flexibility of } \\
\text { regulations or standards }\end{array}$ & $\begin{array}{l}\text { Limitations of science and } \\
\text { technology public policies }\end{array}$ \\
\hline Brazil & 6.4 & 6.8 & 4.6 \\
\hline China & n.a. & n.a. & 10.9 \\
\hline Colombia & n.a. & 35.2 & n.a. \\
\hline Egypt & n.a. & n.a. & n.a. \\
\hline Ghana & n.a. & n.a. & n.a. \\
\hline Indonesia & 13.0 & 21.0 & 27.0 \\
\hline Israel & n.a. & n.a. & n.a. \\
\hline Malaysia & n.a. & 17.0 & n.a. \\
\hline Philippines & n.a. & n.a. & n.a. \\
\hline Russian Federation & n.a. & n.a. & n.a. \\
\hline South Africa & n.a. & n.a. & n.a. \\
\hline Uruguay & 10.3 & n.a. & n.a. \\
\hline EU-27 & n.a. & n.a. & n.a. \\
\hline Eurostat min & n.a. & n.a. & n.a. \\
\hline Eurostat max & n.a. & n.a. & n.a. \\
\hline
\end{tabular}

Notes: Based on a three-year observation period, except for Colombia (2 years), Indonesia (2 years), and Malaysia (4 years).

For Colombia: Sample survey data (no grossed up results). Data only cover product and process innovators.

For Indonesia: The target population was medium-sized and large firms that implemented any type of innovation. No specification of firms covered.

For Malaysia: Data also cover organizational and marketing innovators.

Source: 2011 UIS pilot data collection of innovation statistics. 
Table A9. Highly important cost and economic hampering factors for firms as a percentage of non-innovative manufacturing firms

\begin{tabular}{|c|c|c|c|c|}
\hline & \multicolumn{4}{|c|}{ Cost and economic factors } \\
\hline & $\begin{array}{l}\text { Lack of funds within } \\
\text { your enterprise or } \\
\text { group }\end{array}$ & $\begin{array}{l}\text { Lack of finance from } \\
\text { sources outside your } \\
\text { enterprise }\end{array}$ & $\begin{array}{l}\text { Innovation costs too } \\
\text { high }\end{array}$ & $\begin{array}{c}\text { Excessive perceived } \\
\text { economic risks }\end{array}$ \\
\hline Brazil & n.a. & 11.9 & 17.2 & 14.4 \\
\hline China & n.a. & n.a. & n.a. & n.a. \\
\hline Colombia & 25.6 & 22.2 & n.a. & n.a. \\
\hline Egypt & 17.7 & 17.9 & 14.5 & n.a. \\
\hline Ghana & n.a. & n.a. & n.a. & n.a. \\
\hline Indonesia & n.a. & n.a. & n.a. & n.a. \\
\hline Israel & n.a. & n.a. & n.a. & n.a. \\
\hline Malaysia & n.a. & n.a. & n.a. & n.a. \\
\hline Philippines & 23.9 & 14.5 & 26.0 & n.a. \\
\hline Russian Federation & 32.9 & n.a. & 24.1 & 15.5 \\
\hline South Africa & 31.0 & 20.2 & 24.6 & n.a. \\
\hline Uruguay & n.a. & 24.7 & n.a. & 10.1 \\
\hline EU-27 & n.a. & n.a. & n.a. & n.a. \\
\hline Eurostat min & 9.7 & 4.0 & 3.0 & n.a. \\
\hline Eurostat max & 32.2 & 23.9 & 37.2 & n.a. \\
\hline
\end{tabular}

Notes: Based on a three-year observation period, except for the Russian Federation (1 year), the Philippines (1.5 years), and Colombia (2 years).

For Colombia: Sample survey data (no grossed up results). Data cover firms with abandoned or ongoing activities.

For the Philippines: IT services are also included. Results are not representative of the target population.

For the Russian Federation: Data cover firms without any type of innovation and without abandoned or ongoing activities.

Source: 2011 UIS pilot data collection of innovation statistics and CIS 2006 database (Eurostat, 2012). 
Table A10. Highly important knowledge hampering factors for firms as a percentage of non-innovative manufacturing firms

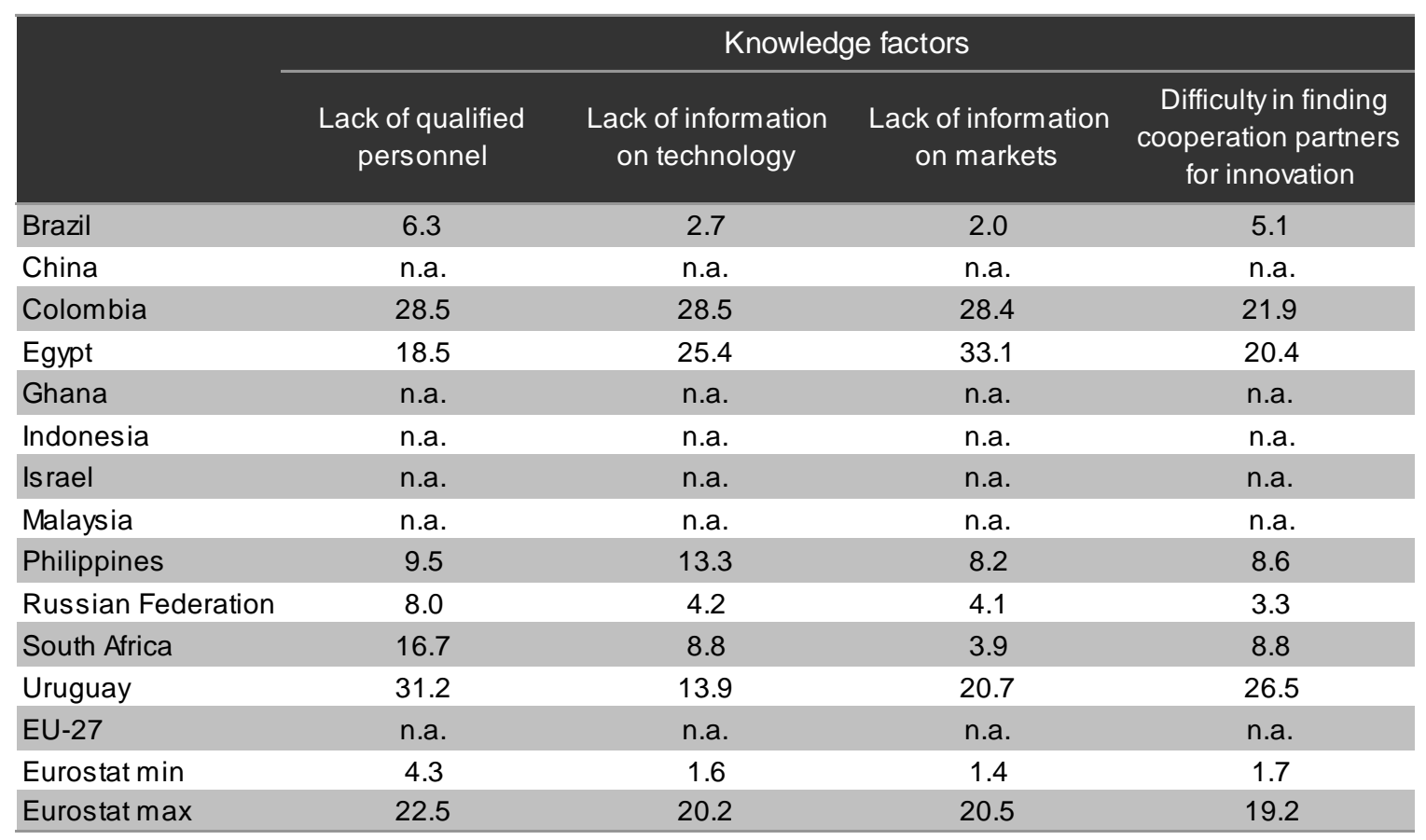

Notes: Based on a three-year observation period, except for the Russian Federation (1 year), the Philippines (1.5 years), and Colombia (2 years).

For Colombia: Sample survey data (no grossed up results). Data cover firms with abandoned or ongoing activities.

For the Philippines: IT services are also included. Results are not representative of the target population.

For the Russian Federation: Data cover firms without any type of innovation and without abandoned or ongoing activities.

Source: 2011 UIS pilot data collection of innovation statistics and CIS 2006 database (Eurostat, 2012). 
Table A11. Highly important market hampering factors for firms as a percentage of non-innovative manufacturing firms

\begin{tabular}{|c|c|c|c|}
\hline & & Market factors & \\
\hline & $\begin{array}{c}\text { Market dominated by } \\
\text { established enterprises }\end{array}$ & $\begin{array}{l}\text { Uncertain demand for } \\
\text { innovative goods or services }\end{array}$ & Innovation is easy to imitate \\
\hline Brazil & n.a. & n.a. & n.a. \\
\hline China & n.a. & n.a. & n.a. \\
\hline Colombia & n.a. & 26.2 & 22.0 \\
\hline Egypt & 17.7 & 21.2 & n.a. \\
\hline Ghana & n.a. & n.a. & n.a. \\
\hline Indonesia & n.a. & n.a. & n.a. \\
\hline Israel & n.a. & n.a. & n.a. \\
\hline Malaysia & n.a. & n.a. & n.a. \\
\hline Philippines & 16.0 & 12.1 & n.a. \\
\hline Russian Federation & n.a. & n.a. & n.a. \\
\hline South Africa & 28.3 & 19.1 & n.a. \\
\hline Uruguay & n.a. & n.a. & n.a. \\
\hline EU-27 & n.a. & n.a. & n.a. \\
\hline Eurostat min & 3.7 & 5.3 & n.a. \\
\hline Eurostat max & 25.3 & 22.8 & n.a. \\
\hline
\end{tabular}

Notes: Based on a three-year observation period, except for the Philippines (1.5 years) and Colombia (2 years).

For Colombia: Sample survey data (no grossed up results). Data cover firms with abandoned or ongoing activities.

For the Philippines: IT services are also included. Results are not representative of the target population.

Source: 2011 UIS pilot data collection of innovation statistics and CIS 2006 database (Eurostat, 2012). 
Table A12. Other highly important hampering factors for firms as a percentage of non-innovative manufacturing firms

\begin{tabular}{|c|c|c|c|}
\hline & \multicolumn{3}{|c|}{ Other factors } \\
\hline & $\begin{array}{c}\text { Organisational rigidities } \\
\text { within the enterprise }\end{array}$ & $\begin{array}{l}\text { Insufficient flexibility of } \\
\text { regulations or standards }\end{array}$ & $\begin{array}{l}\text { Limitations of science and } \\
\text { technology public policies }\end{array}$ \\
\hline Brazil & 2.0 & 4.2 & 3.1 \\
\hline China & n.a. & n.a. & n.a. \\
\hline Colombia & n.a. & 24.8 & n.a. \\
\hline Egypt & n.a. & n.a. & n.a. \\
\hline Ghana & n.a. & n.a. & n.a. \\
\hline Indonesia & n.a. & n.a. & n.a. \\
\hline Israel & n.a. & n.a. & n.a. \\
\hline Malaysia & n.a. & n.a. & n.a. \\
\hline Philippines & n.a. & n.a. & n.a. \\
\hline Russian Federation & n.a. & n.a. & n.a. \\
\hline South Africa & n.a. & n.a. & n.a. \\
\hline Uruguay & 7.8 & n.a. & n.a. \\
\hline EU-27 & n.a. & n.a. & n.a. \\
\hline Eurostat min & n.a. & n.a. & n.a. \\
\hline Eurostat max & n.a. & n.a. & n.a. \\
\hline
\end{tabular}

Notes: Based on a three-year observation period, except for Colombia (2 years).

For Colombia: Sample survey data (no grossed up results). Data cover firms with abandoned or ongoing activities.

Source: 2011 UIS pilot data collection of innovation statistics. 
Table A13. Manufacturing firms that implement organizational innovation as a percentage of all manufacturing firms

\begin{tabular}{lc|}
\hline Brazil & $\begin{array}{c}\text { Organisational } \\
\text { innovators } \\
\text { in manufacturing }\end{array}$ \\
\hline China & 54.0 \\
Colombia & n.a. \\
Egypt & 13.6 \\
Ghana & 6.2 \\
Indonesia & n.a. \\
Israel & n.a. \\
Malaysia & 50.6 \\
Philippines & 28.1 \\
Russian Federation & 58.0 \\
South Africa & 4.0 \\
\hline Uruguay & 52.6 \\
\hline EU-27 & 8.4 \\
\hline Eurostat min & 30.8 \\
\hline Eurostat max & 10.1 \\
\hline
\end{tabular}

Notes: Based on a three-year observation period, except for the Russian Federation (1 year), the Philippines (1.5 years), Colombia (2 years), and Malaysia (4 years).

For Colombia: Sample survey data (no grossed up results).

For the Philippines: IT services are also included. Results are not representative of the target population.

For Egypt, Malaysia, the Philippines and South Africa: Organizational innovation includes new or significant changes.

For Brazil: Environmental management techniques are included and methods to organize external relations can be new or significantly changed.

Source: 2011 UIS pilot data collection of innovation statistics and CIS 2008 database (Eurostat, 2012). 
Table A14. Manufacturing firms that implement organizational innovation by size class as a percentage of manufacturing firms in each size class

\begin{tabular}{lcccc} 
& \multicolumn{3}{c}{ Size class } \\
\cline { 2 - 4 } & Micro & Small & Medium-sized & Large \\
\hline Brazil & n.a. & n.a. & n.a. & n.a. \\
China & n.a. & n.a. & n.a. & n.a. \\
Colombia & n.a. & 9.1 & 19.8 & 31.0 \\
Egypt & 2.6 & 6.3 & 6.6 & 14.9 \\
Ghana & n.a. & n.a. & n.a. & n.a. \\
Indonesia & n.a. & n.a. & n.a. & n.a. \\
Israel & n.a. & 44.0 & 66.6 & 72.0 \\
Malaysia & n.a. & 12.8 & 29.9 & 46.2 \\
Philippines & 39.0 & 52.0 & 70.0 & 67.0 \\
Russian Federation & n.a. & n.a. & 1.7 & 9.5 \\
South Africa & 44.9 & 55.9 & 57.4 & 71.1 \\
\hline Uruguay & n.a. & 3.4 & 15.0 & 22.0 \\
EU-27 & n.a. & 26.8 & n.a. & n.a. \\
\hline Eurostat min & n.a. & 9.1 & 10.2 & 33.3 \\
\hline Eurostat max & n.a. & 47.1 & 66.7 & 74.1 \\
\hline
\end{tabular}

Notes: Based on a three-year observation period, except for the Russian Federation (1 year), the Philippines (1.5 years), Colombia (2 years), and Malaysia (4 years).

For Colombia: Sample survey data (no grossed up results).

For the Philippines: IT services are also included. Results are not representative of the target population.

For Egypt, Malaysia, the Philippines and South Africa: Organizational innovation includes new or significant changes.

Size classes are detailed in Annex II.

Source: 2011 UIS pilot data collection of innovation statistics and CIS 2008 database (Eurostat, 2012). 
Table A15. Manufacturing firms that implement marketing innovation as a percentage of all manufacturing firms

\begin{tabular}{lc}
\hline & $\begin{array}{c}\text { Marketing } \\
\text { innovators } \\
\text { in manufacturing }\end{array}$ \\
\hline Brazil & 48.0 \\
China & n.a. \\
Colombia & 10.8 \\
Egypt & 3.6 \\
Ghana & n.a. \\
\hline Indonesia & n.a. \\
\hline Israel & 57.9 \\
\hline Malaysia & 28.0 \\
Philippines & 50.4 \\
Russian Federation & 3.4 \\
South Africa & 23.3 \\
\hline Uruguay & 4.8 \\
\hline EU-27 & 27.5 \\
\hline Eurostat min & 11.4 \\
\hline Eurostat max & 60.4 \\
\hline
\end{tabular}

Notes: Based on a three-year observation period, except for the Russian Federation (1 year), the Philippines (1.5 years), Colombia (2 years), and Malaysia (4 years).

For Colombia: Sample survey data (no grossed up results).

For the Philippines: IT services are also included. Results are not representative of the target population.

For Colombia, Egypt, Malaysia and South Africa: Significant changes other than in design or packaging are also included.

Source: 2011 UIS pilot data collection of innovation statistics and CIS 2008 database (Eurostat, 2012). 
Table A16. Manufacturing firms that implement marketing innovation by size class as a percentage of manufacturing firms in each size class

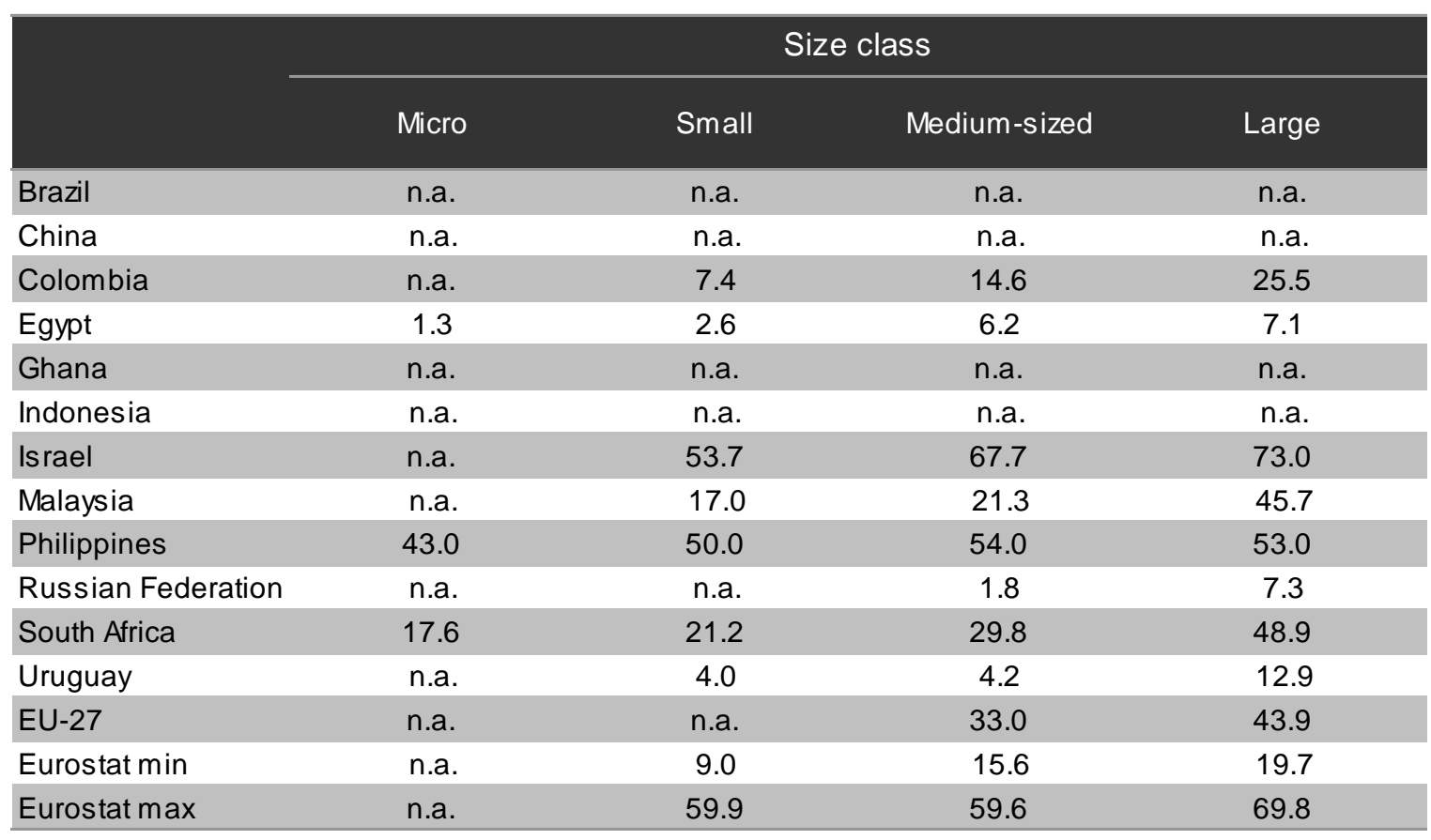

Notes: Based on a three-year observation period, except for the Russian Federation (1 year), the Philippines (1.5 years), Colombia (2 years), and Malaysia (4 years).

For Colombia: Sample survey data (no grossed up results).

For the Philippines: IT services are also included. Results are not representative of the target population.

For Colombia, Egypt, Malaysia and South Africa: Significant changes other than in design or packaging are also included.

Size classes are detailed in Annex II.

Source: 2011 UIS pilot data collection of innovation statistics and CIS 2008 database (Eurostat, 2012). 
Table A17. Manufacturing firms that implement any type of innovation as a percentage of all manufacturing firms

\begin{tabular}{lc}
\hline & $\begin{array}{c}\text { Innovators } \\
\text { in manufacturing }\end{array}$ \\
\hline Brazil & 75.0 \\
China & n.a. \\
Colombia & 27.0 \\
Egypt & 12.8 \\
Ghana & n.a. \\
Indonesia & n.a. \\
\hline Israel & 74.2 \\
\hline Malaysia & n.a. \\
Philippines & n.a. \\
Russian Federation & 13.0 \\
\hline South Africa & 60.3 \\
\hline Uruguay & 31.5 \\
\hline EU-27 & 54.5 \\
\hline Eurostat min & 28.4 \\
\hline Eurostat max & 86.3 \\
\hline
\end{tabular}

Notes: Based on a three-year observation period, except for the Russian Federation (1 year) and Colombia (2 years).

For Colombia: Sample survey data (no grossed up results).

Source: 2011 UIS pilot data collection of innovation statistics and CIS 2008 database (Eurostat, 2012). 
Table A18. Manufacturing firms that implement any type of innovation by size class as a percentage of manufacturing firms in each size class

\begin{tabular}{|c|c|c|c|c|}
\hline & \multicolumn{4}{|c|}{ Size class } \\
\hline & Micro & Small & Medium-sized & Large \\
\hline Brazil & n.a. & n.a. & n.a. & n.a. \\
\hline China & n.a. & n.a. & n.a. & n.a. \\
\hline Colombia & n.a. & 19.2 & 38.5 & 55.0 \\
\hline Egypt & n.a. & n.a. & n.a. & n.a. \\
\hline Ghana & n.a. & n.a. & n.a. & n.a. \\
\hline Indonesia & n.a. & n.a. & n.a. & n.a. \\
\hline Israel & n.a. & 70.5 & 82.9 & 89.2 \\
\hline Malaysia & n.a. & n.a. & n.a. & n.a. \\
\hline Philippines & n.a. & n.a. & n.a. & n.a. \\
\hline Russian Federation & n.a. & n.a. & 6.7 & 28.0 \\
\hline South Africa & n.a. & n.a. & n.a. & n.a. \\
\hline Uruguay & n.a. & n.a. & n.a. & n.a. \\
\hline EU-27 & n.a. & 49.7 & n.a. & n.a. \\
\hline Eurostat min & n.a. & 22.6 & 38.2 & 59.9 \\
\hline Eurostat max & n.a. & 84.2 & 89.9 & 97.2 \\
\hline
\end{tabular}

Notes: Based on a three-year observation period, except for the Russian Federation (1 year) and Colombia (2 years).

For Colombia: Sample survey data (no grossed up results).

Size classes are detailed in Annex II.

Source: 2011 UIS pilot data collection of innovation statistics and CIS 2008 database (Eurostat, 2012). 


\section{Annex II. Basic methodology}

Table A19. Basic methodology of the national innovation surveys

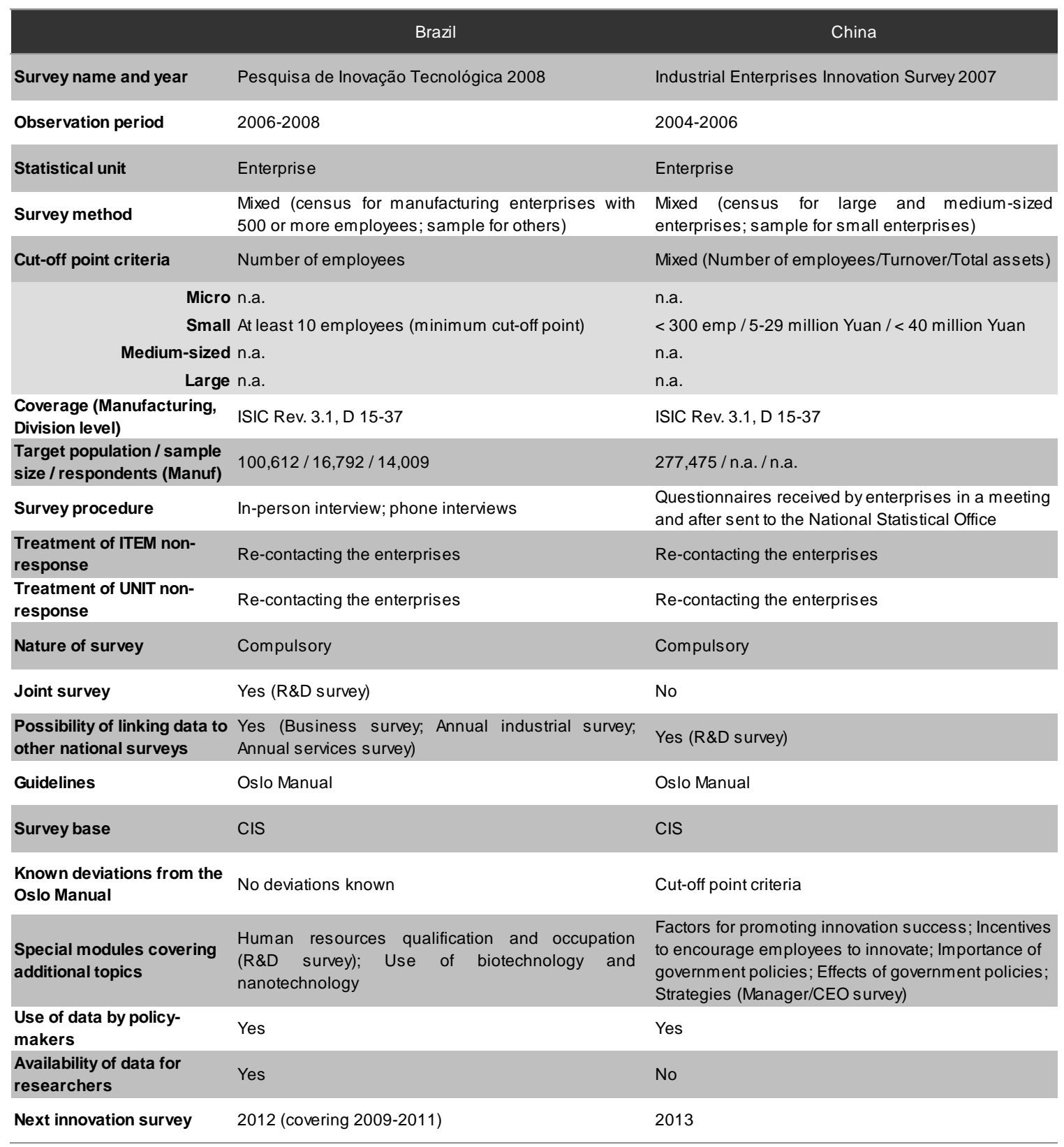


Table A19. Basic methodology of the national innovation surveys (cont.)

\begin{tabular}{|c|c|c|}
\hline & Colombia & Egypt \\
\hline Survey name and year & $\begin{array}{l}\text { Cuarta Encuesta de Desarrollo e Innovación } \\
\text { Tecnológica en la Industria Colombiana } 2009\end{array}$ & Egyptian National Innovation Indicators Survey 2011 \\
\hline Observation period & $2007-2008$ & $2008-2010$ \\
\hline Statistical unit & Enterprise & Enterprise \\
\hline Survey method & Census & Sample \\
\hline Cut-off point criteria & Number of employees & Number of employees \\
\hline Micro & n.a. & $1-10$ employees \\
\hline Small & 1-50 employees & $11-50$ employees \\
\hline Medium-sized & 51-200 employees & 51-250 employees \\
\hline Large & More than 200 employees & More than 250 employees \\
\hline $\begin{array}{l}\text { Coverage (Manufacturing, } \\
\text { Division level) }\end{array}$ & ISIC Rev. 3.1, D 15-37 & ISIC Rev. 4, C 10-18/20-23/25/27/28/30-33 \\
\hline $\begin{array}{l}\text { Target population / sample } \\
\text { size / respondents (Manuf) }\end{array}$ & n.a./n.a. / 7,683 & n.a. / 1,111/n.a. \\
\hline Survey procedure & Electronic form & In-person interview \\
\hline $\begin{array}{l}\text { Treatment of ITEM non- } \\
\text { response }\end{array}$ & Re-contacting the enterprises & Re-contacting the enterprises \\
\hline $\begin{array}{l}\text { Treatment of UNIT non- } \\
\text { response }\end{array}$ & Re-contacting the enterprises & Re-contacting the enterprises and replacement \\
\hline Nature of survey & Compulsory & Voluntary \\
\hline Joint survey & No & Yes (R\&D survey) \\
\hline $\begin{array}{l}\text { Possibility of linking data to } \\
\text { other national surveys }\end{array}$ & Yes (Business survey) & Yes (R\&D survey) \\
\hline Guidelines & Oslo and Bogota Manuals & Oslo Manual \\
\hline Survey base & CIS & South African Innovation Survey \\
\hline $\begin{array}{l}\text { Known deviations from the } \\
\text { Oslo Manual }\end{array}$ & Cut-off point criteria & Cut-off point criteria \\
\hline $\begin{array}{l}\text { Special modules covering } \\
\text { additional topics }\end{array}$ & Human resources qualification and occupation & None \\
\hline $\begin{array}{l}\text { Use of data by policy- } \\
\text { makers }\end{array}$ & Yes & Yes \\
\hline $\begin{array}{l}\text { Availability of data for } \\
\text { researchers }\end{array}$ & Yes & Yes \\
\hline Next innovation survey & Currently being carried out & n.a. \\
\hline
\end{tabular}


Table A19. Basic methodology of the national innovation surveys (cont.)

\begin{tabular}{|c|c|c|}
\hline & Ghana & Indonesia \\
\hline Survey name and year & The Ghana Innovation Survey 2009 & $\begin{array}{l}\text { The Survey of Innovation in the Manufacturing } \\
\text { Industry } 2011\end{array}$ \\
\hline Observation period & $2005-2007$ & $2009-2010$ \\
\hline Statistical unit & Enterprise & Establishment \\
\hline Survey method & Sample & Sample \\
\hline Cut-off point criteria & Number of employees & Number of employees \\
\hline Micro & n.a. & n.a. \\
\hline Small & 5-19 employees & n.a. \\
\hline Medium-sized & 20-99 employees & 20-99 employees \\
\hline Large & 100 or more employees & 100 or more employees \\
\hline $\begin{array}{l}\text { Coverage (Manufacturing, } \\
\text { Division level) }\end{array}$ & ISIC Rev. 3.1, D 15/17/18/20-28/36 & ISIC Rev. 3.1, D 15-37 \\
\hline $\begin{array}{l}\text { Target population / sample } \\
\text { size / respondents (Manuf) }\end{array}$ & n.a./n.a./ 86 & $27,854 / 1,500 / 1,385$ \\
\hline Survey procedure & In-person interview & In-person interview \\
\hline $\begin{array}{l}\text { Treatment of ITEM non- } \\
\text { response }\end{array}$ & Re-contacting the enterprises & Re-contacting the enterprises \\
\hline $\begin{array}{l}\text { Treatment of UNIT non- } \\
\text { response }\end{array}$ & Re-contacting the enterprises & Re-contacting the enterprises \\
\hline Nature of survey & Voluntary & Voluntary \\
\hline Joint survey & Yes (R\&D survey) & No \\
\hline $\begin{array}{l}\text { Possibility of linking data to } \\
\text { other national surveys }\end{array}$ & Yes (Business survey) & Yes (R\&D survey) \\
\hline Guidelines & Oslo Manual & Oslo Manual \\
\hline Survey base & n.a. & Not based on other innovation survey \\
\hline $\begin{array}{l}\text { Known deviations from the } \\
\text { Oslo Manual }\end{array}$ & Cut-off point criteria & $\begin{array}{l}\text { Observation period; statistical unit; cut-off point } \\
\text { criteria }\end{array}$ \\
\hline $\begin{array}{l}\text { Special modules covering } \\
\text { additional topics }\end{array}$ & Specific innovations & Innovation drivers \\
\hline $\begin{array}{l}\text { Use of data by policy- } \\
\text { makers }\end{array}$ & Not aware & Not aware \\
\hline $\begin{array}{l}\text { Availability of data for } \\
\text { researchers }\end{array}$ & Yes & No \\
\hline Next innovation survey & 2011 (still ongoing) & 2013 \\
\hline
\end{tabular}


Table A19. Basic methodology of the national innovation surveys (cont.)

\begin{tabular}{|c|c|c|}
\hline & Israel & Malaysia \\
\hline Survey name and year & Israel's Business Innovation Survey 2010/2011 & Fifth National Survey of Innovation 2009 \\
\hline Observation period & $2006-2008$ & $2005-2008$ \\
\hline Statistical unit & Enterprise & Establishment \\
\hline Survey method & Sample & Sample \\
\hline Cut-off point criteria & Number of employees & Mixed (Number of employees/Turnover) \\
\hline Micro & n.a. & n.a. \\
\hline Small & 10-49 employees & 5-50 emp / 250,000-10 million Ringgit Malaysia \\
\hline Medium-sized & 50-249 employees & 51-150 emp / 10-25 million RM \\
\hline Large & 250 or more employees & More than $150 \mathrm{emp} /$ More than 25 million RM \\
\hline $\begin{array}{l}\text { Coverage (Manufacturing, } \\
\text { Division level) }\end{array}$ & ISIC Rev. 3.1, D 15-37 & ISIC Rev. 3.1, D 15/17-37 \\
\hline $\begin{array}{l}\text { Target population / sample } \\
\text { size / respondents (Manuf) }\end{array}$ & $4,921 / 1,012$ / 921 & n.a. $/ 4,000 / 1,017$ \\
\hline Survey procedure & Mail; phone interview & $\begin{array}{l}\text { Mail; in-person interview; phone interview; workshop, } \\
\text { seminar and group briefing }\end{array}$ \\
\hline $\begin{array}{l}\text { Treatment of ITEM non- } \\
\text { response }\end{array}$ & Imputation* & Re-contacting the enterprises \\
\hline $\begin{array}{l}\text { Treatment of UNIT non- } \\
\text { response }\end{array}$ & Imputation* & Re-contacting the enterprises \\
\hline Nature of survey & Compulsory & Voluntary \\
\hline Joint survey & $\begin{array}{l}\text { Yes (R\&D survey; ICT usage survey; Manpower } \\
\text { structure survey) }\end{array}$ & No \\
\hline $\begin{array}{l}\text { Possibility of linking data to } \\
\text { other national surveys }\end{array}$ & Yes (Business survey) & Yes (R\&D survey) \\
\hline Guidelines & Oslo Manual & Oslo Manual \\
\hline Survey base & CIS 2008 & CIS 4 \\
\hline $\begin{array}{l}\text { Known deviations from the } \\
\text { Oslo Manual }\end{array}$ & No deviations known & $\begin{array}{l}\text { Observation period; statistical unit; cut-off point } \\
\text { criteria; modules answered by firms with any type of } \\
\text { inovation }\end{array}$ \\
\hline $\begin{array}{l}\text { Special modules covering } \\
\text { additional topics }\end{array}$ & None other than the combined surveys & $\begin{array}{l}\text { Government support for innovation; Role of } \\
\text { government in innovation }\end{array}$ \\
\hline $\begin{array}{l}\text { Use of data by policy- } \\
\text { makers }\end{array}$ & n.a. & Yes \\
\hline $\begin{array}{l}\text { Availability of data for } \\
\text { researchers }\end{array}$ & No & Yes \\
\hline Next innovation survey & n.a. & 2012 \\
\hline
\end{tabular}

*'Close neighbor': probit regression to impute data from a similar unit to a non-response unit. Data on expenditures, employees etc. were gathered from administrative data and imputed using industries average for data breakdowns. 
Table A19. Basic methodology of the national innovation surveys (cont.)

\begin{tabular}{|c|c|c|}
\hline & Philippines & Russian Federation \\
\hline Survey name and year & $\begin{array}{l}\text { Survey of Innovation Activities by Establishments } \\
2010\end{array}$ & Russian innovation survey 2011 \\
\hline Observation period & Jan 2009-Jun 2010 & 2010 \\
\hline Statistical unit & Establishment & Enterprise \\
\hline Survey method & Sample & Census \\
\hline Cut-off point criteria & Number of employees & Mixed (Number of employees/Turnover) \\
\hline Micro & 1-9 employees & n.a. \\
\hline Small & 10-99 employees & n.a. \\
\hline Medium-sized & 100-199 employees & 101-250 emp / 401-1.000 million Roubles \\
\hline Large & 200 or more employees & 250 emp and more / 1.000 million RUB and more \\
\hline $\begin{array}{l}\text { Coverage (Manufacturing, } \\
\text { Division level) }\end{array}$ & ISIC Rev. 3.1, D 15/32 & NACE 1.1, D 15-37 \\
\hline $\begin{array}{l}\text { Target population / sample } \\
\text { size / respondents (Manuf) }\end{array}$ & $1,824 / 500 / 474$ & n.a./n.a./n.a. \\
\hline Survey procedure & n.a. & Mail \\
\hline $\begin{array}{l}\text { Treatment of ITEM non- } \\
\text { response }\end{array}$ & No treatment & Re-contacting the enterprises \\
\hline $\begin{array}{l}\text { Treatment of UNIT non- } \\
\text { response }\end{array}$ & No treatment & Re-contacting the enterprises \\
\hline Nature of survey & Voluntary & Compulsory \\
\hline Joint survey & No & No \\
\hline $\begin{array}{l}\text { Possibility of linking data to } \\
\text { other national surveys }\end{array}$ & No & $\begin{array}{l}\text { Yes (Russian innovation survey of small } \\
\text { enterprises) }\end{array}$ \\
\hline Guidelines & Oslo Manual & Oslo Manual \\
\hline Survey base & $\begin{array}{l}\text { CIS } 4 \text { (with refinements on questionnaire to } \\
\text { consider Philippine setting) }\end{array}$ & CIS 2008 \\
\hline $\begin{array}{l}\text { Known deviations from the } \\
\text { Oslo Manual }\end{array}$ & $\begin{array}{l}\text { Statistical unit; cut-off point criteria; coverage; } \\
\text { treatment of non-response }\end{array}$ & Cut-off point criteria \\
\hline $\begin{array}{l}\text { Special modules covering } \\
\text { additional topics }\end{array}$ & $\begin{array}{l}\text { Knowledge management; Response to government } \\
\text { innovation-related policies }\end{array}$ & None \\
\hline $\begin{array}{l}\text { Use of data by policy- } \\
\text { makers }\end{array}$ & Yes & Yes \\
\hline $\begin{array}{l}\text { Availability of data for } \\
\text { researchers }\end{array}$ & Yes & No \\
\hline Next innovation survey & Not aware & 2012 \\
\hline
\end{tabular}


Table A19. Basic methodology of the national innovation surveys (cont.)

\begin{tabular}{|c|c|c|}
\hline & South Africa & Uruguay \\
\hline Survey name and year & South African National Innovation Survey 2008 & $\begin{array}{l}\text { IV Encuesta de Actividades de Innovación en } \\
\text { Industria } 2010\end{array}$ \\
\hline Observation period & $2005-2007$ & 2007-2009 \\
\hline Statistical unit & Enterprise & Enterprise \\
\hline Survey method & Sample & Mixed \\
\hline Cut-off point criteria & Turnover & Mixed \\
\hline Micro & Less than 5 million South African Rand & n.a. \\
\hline Small & 5-13 million South African Rand & 5-19 emp / 7,565.3-37,824.5 thousand Ur Pesos \\
\hline Medium-sized & 13-51 million South African Rand & 20-99 emp / 37,826.4-283,678.3 thousand Ur Pesos \\
\hline Large & More than 51 million South African Rand & More than $99 \mathrm{emp} />283,680.2$ thousand Ur Pesos \\
\hline $\begin{array}{l}\text { Coverage (Manufacturing, } \\
\text { Division level) }\end{array}$ & ISIC Rev. 3.1, D 15-37 & ISIC Rev. 4, C 10-33 \\
\hline $\begin{array}{l}\text { Target population / sample } \\
\text { size / respondents (Manuf) }\end{array}$ & 12,094 / 1,237 / 301 & $3,928 / 1,023 / 941$ \\
\hline Survey procedure & Email; mail; phone interview & In-person and phone interview \\
\hline $\begin{array}{l}\text { Treatment of ITEM non- } \\
\text { response }\end{array}$ & Imputation* & Re-contacting the enterprises \\
\hline $\begin{array}{l}\text { Treatment of UNIT non- } \\
\text { response }\end{array}$ & Non-response survey & Re-contacting the enterprises \\
\hline Nature of survey & Voluntary & Compulsory \\
\hline Joint survey & No & No \\
\hline $\begin{array}{l}\text { Possibility of linking data to } \\
\text { other national surveys }\end{array}$ & Yes (R\&D survey) & Yes, Business survey \\
\hline Guidelines & Oslo Manual & Yes, Bogota Manual \\
\hline Survey base & CIS 2006 & Not based on other innovation survey \\
\hline $\begin{array}{l}\text { Known deviations from the } \\
\text { Oslo Manual }\end{array}$ & Cut-off point criteria & Cut-off point criteria \\
\hline $\begin{array}{l}\text { Special modules covering } \\
\text { additional topics }\end{array}$ & Specific innovations & $\begin{array}{l}\text { Human resources qualification and occupation; } \\
\text { Organisation of work process (expanded module); } \\
\text { Quality-related activities (expanded module) }\end{array}$ \\
\hline $\begin{array}{l}\text { Use of data by policy- } \\
\text { makers }\end{array}$ & Yes & Yes (partially) \\
\hline $\begin{array}{l}\text { Availability of data for } \\
\text { researchers }\end{array}$ & Yes & Yes \\
\hline Next innovation survey & 2012 & 2013 \\
\hline
\end{tabular}

*Applied to quantitative variables only (turnover, expenditure on innovation and number of employees). The imputed value was taken as the arithmetic mean based on all responses in the sector and size class in which the missing value occurs.

Source: UIS 2011 pilot data collection of innovation statistics. 


\section{Annex III. Country profiles}

\section{BRAZIL AT A GLANCE}

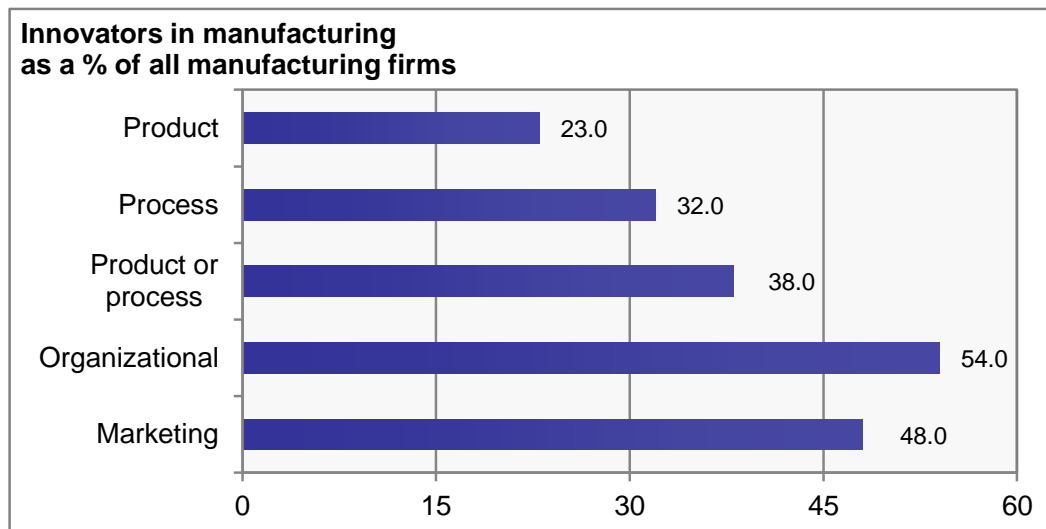

Notes: Organizational innovation includes environmental management techniques and methods to organize external relations can be new or significantly changed.
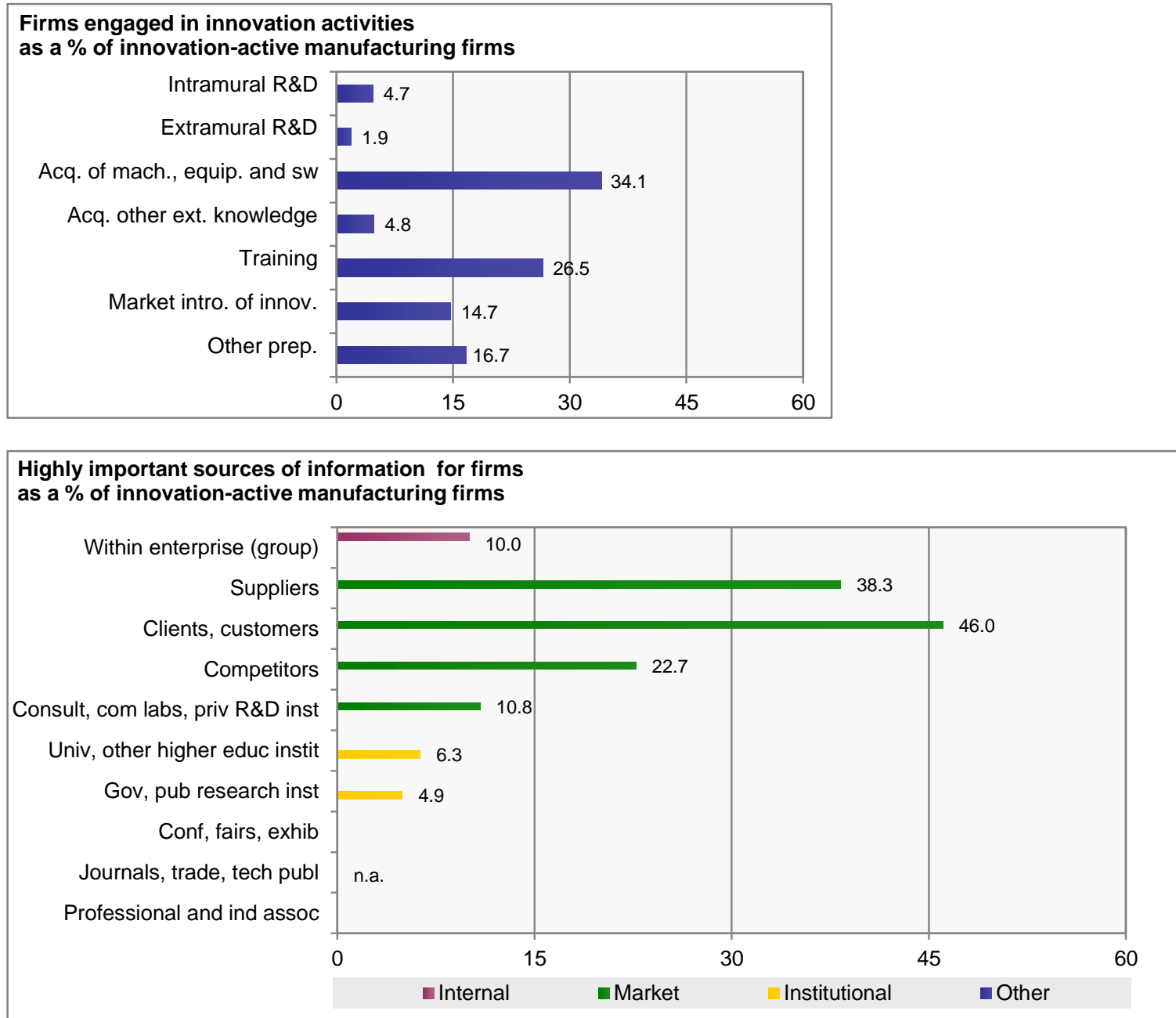

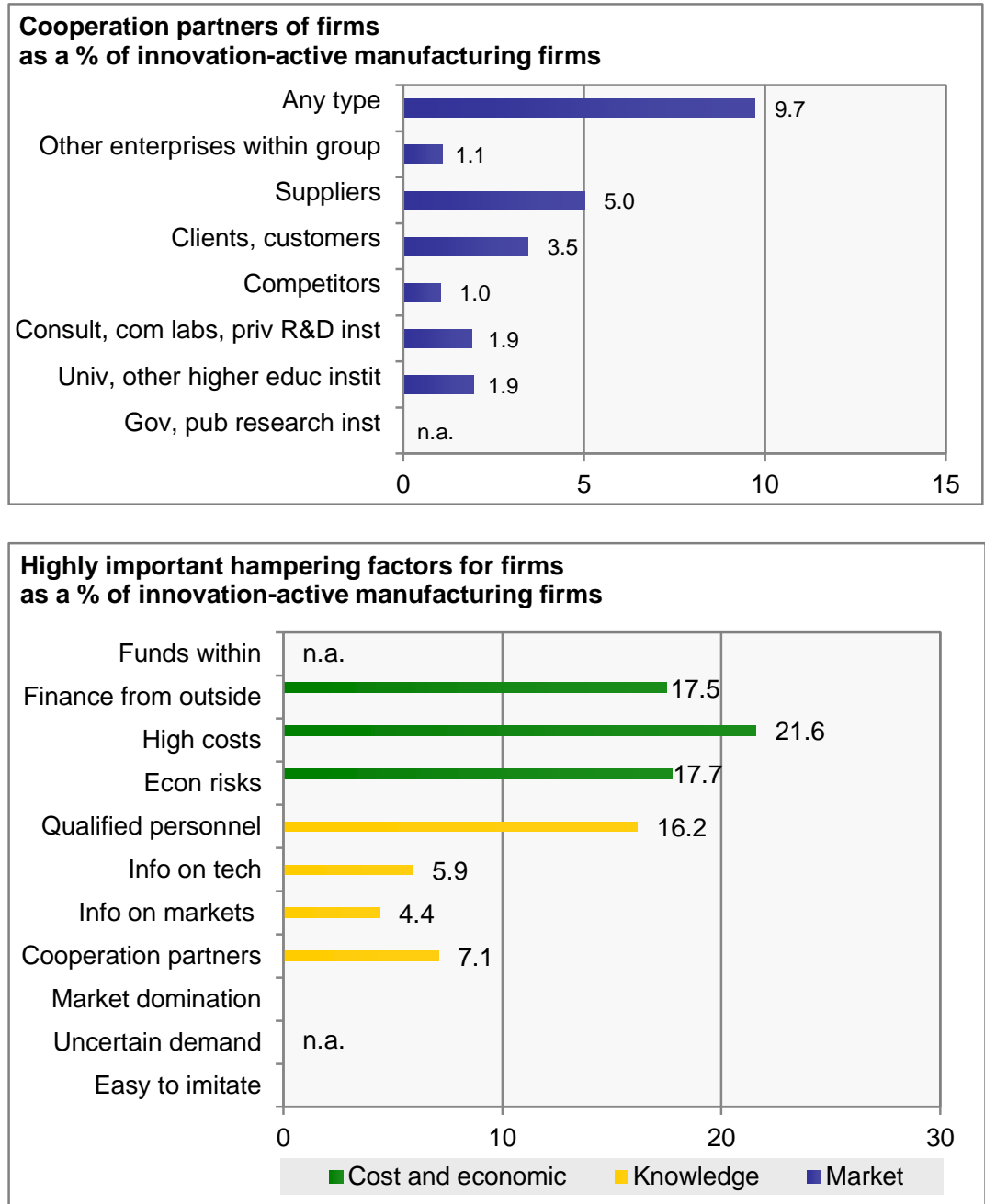

General notes: Based on a three-year observation period. For more specifications please consult the full report. 


\section{CHINA AT A GLANCE}

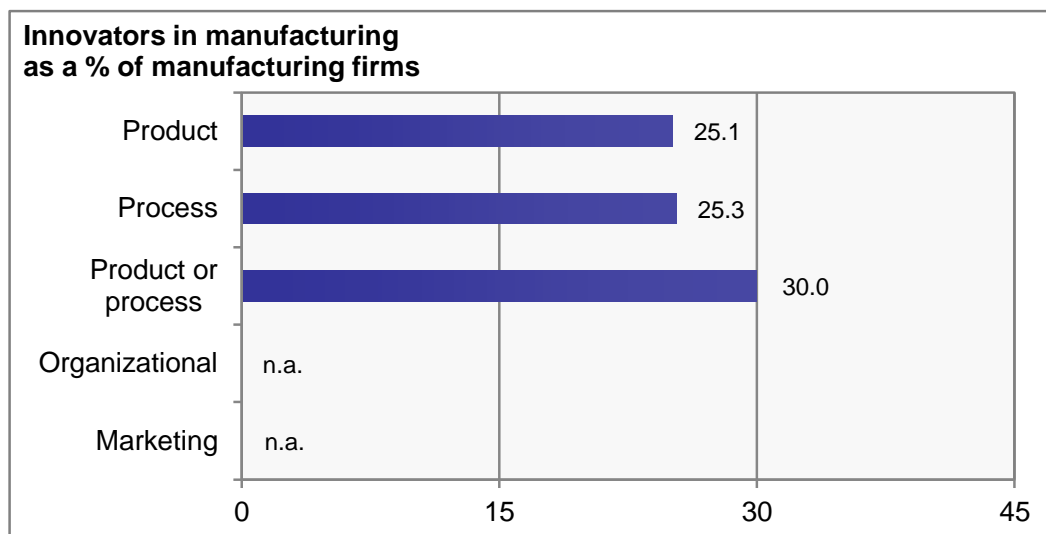

Notes: Product innovation covers only new or significantly improved goods. Logistics, delivery or distribution methods are not explicitly mentioned in process innovation.

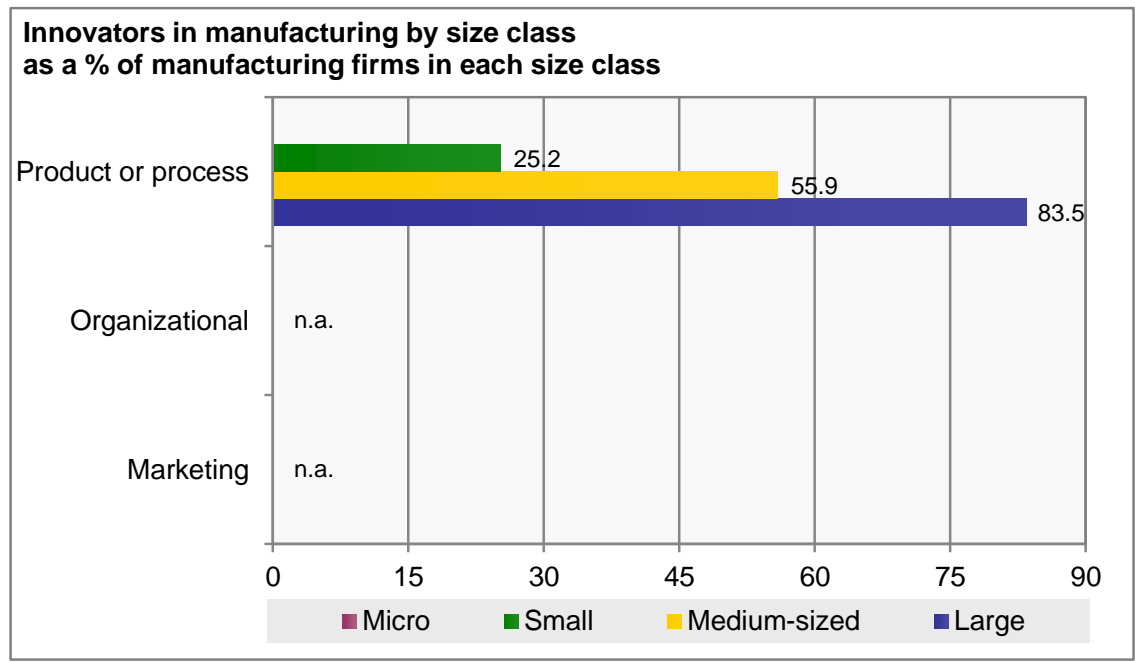

Notes: Product innovation covers only new or significantly improved goods. Logistics, delivery or distribution methods are not explicitly mentioned in process innovation. Data broken down by size class cover manufacturing, mining and quarrying, as well as electricity, gas and water supply.

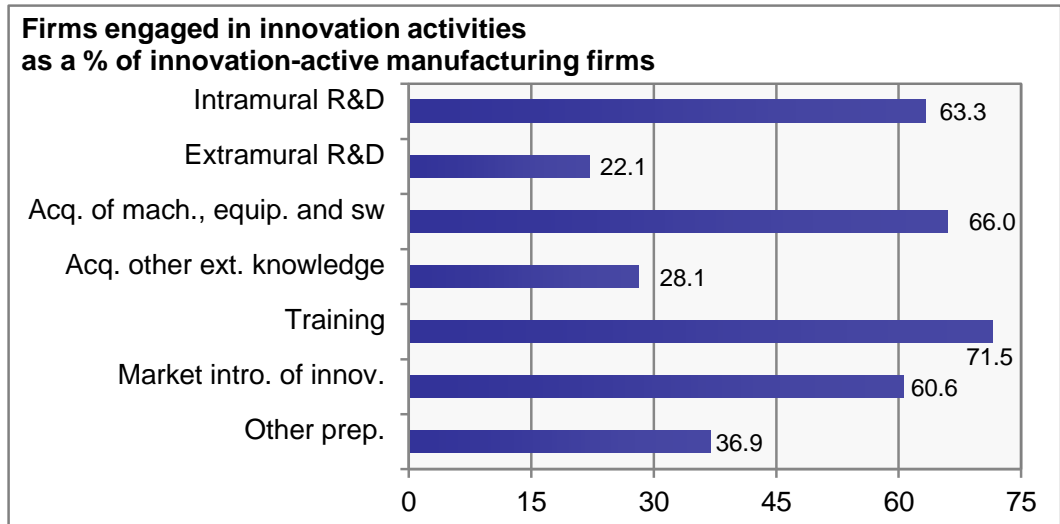



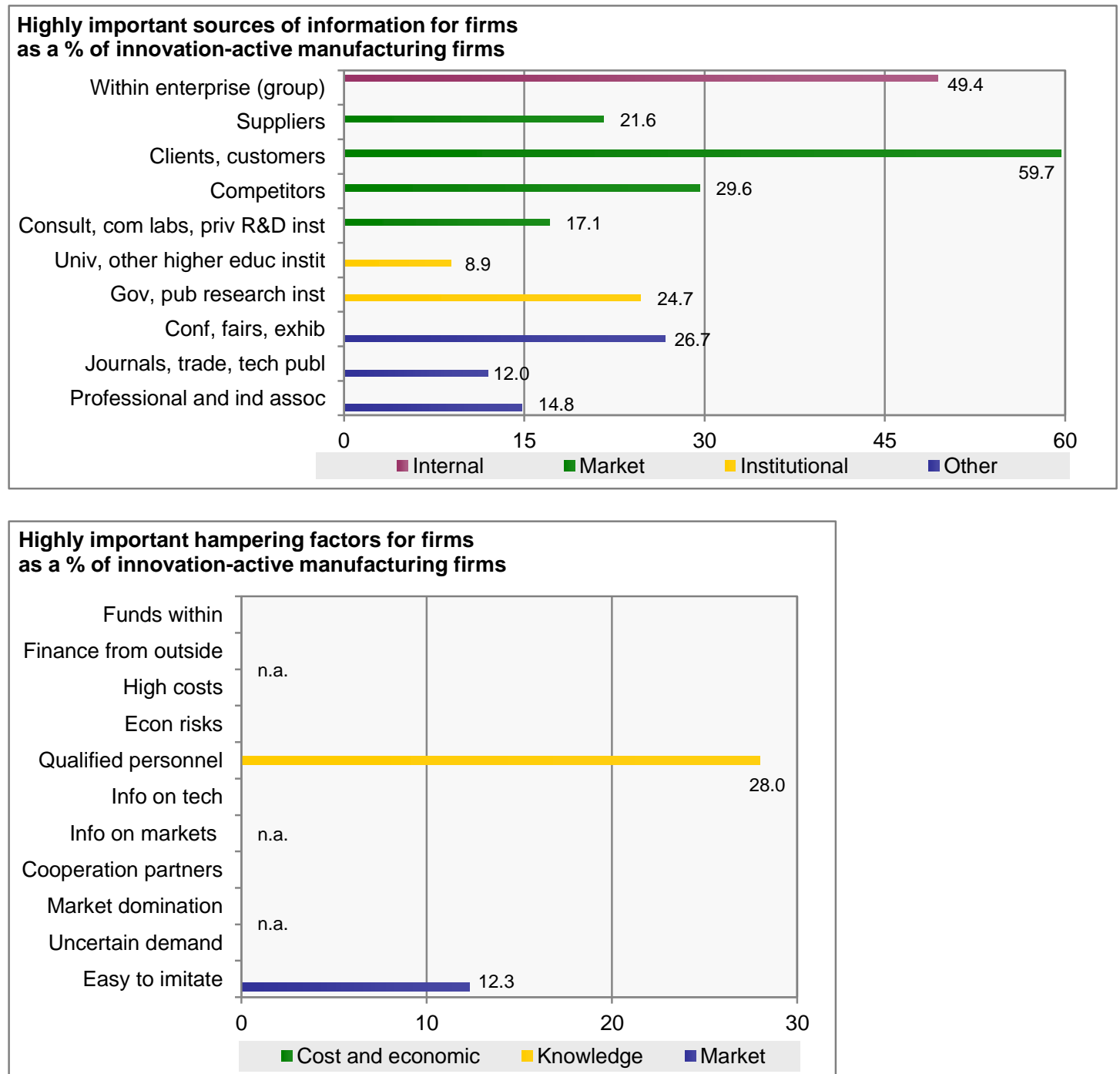

Notes: Lack of qualified personnel refers to lack of technical personnel or 'brain drain' of technical talents. Innovation is easy to imitate refers to counterfeiting or import competition.

General notes: Based on a three-year observation period. For more specifications please consult the full report. 


\section{COLOMBIA AT A GLANCE}

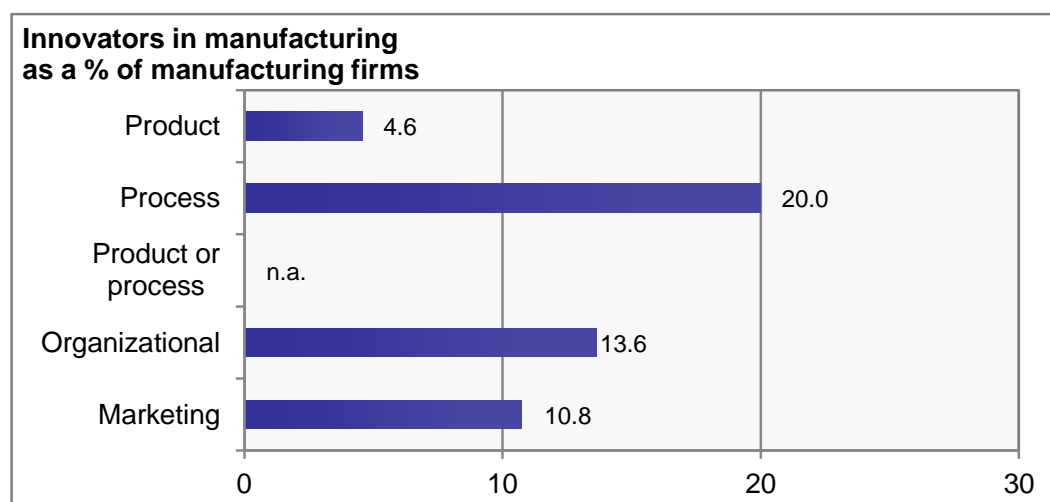

Notes: Marketing innovation includes significant changes other than in design or packaging.

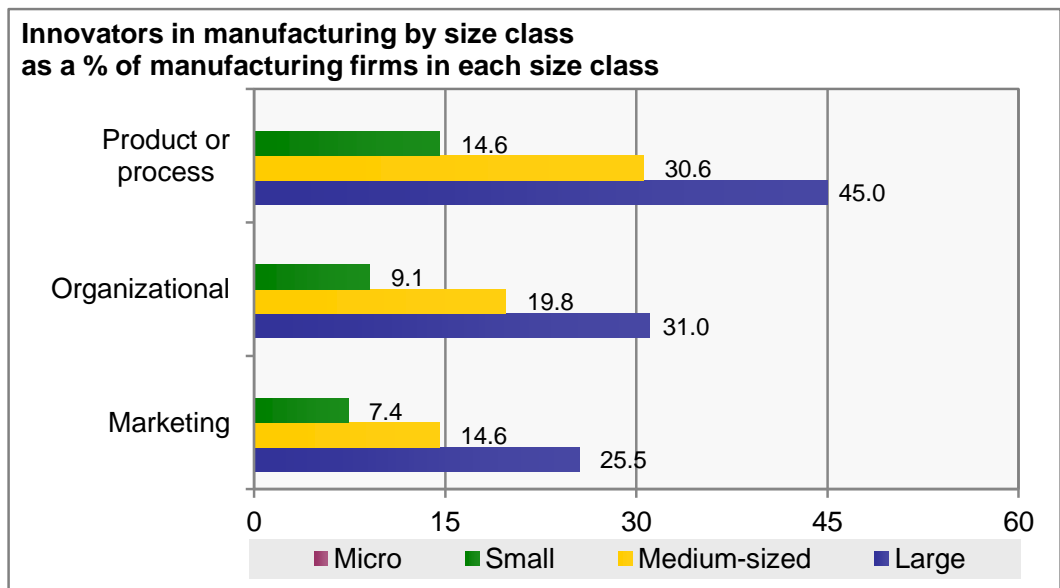

Notes: Marketing innovation includes significant changes other than in design or packaging.

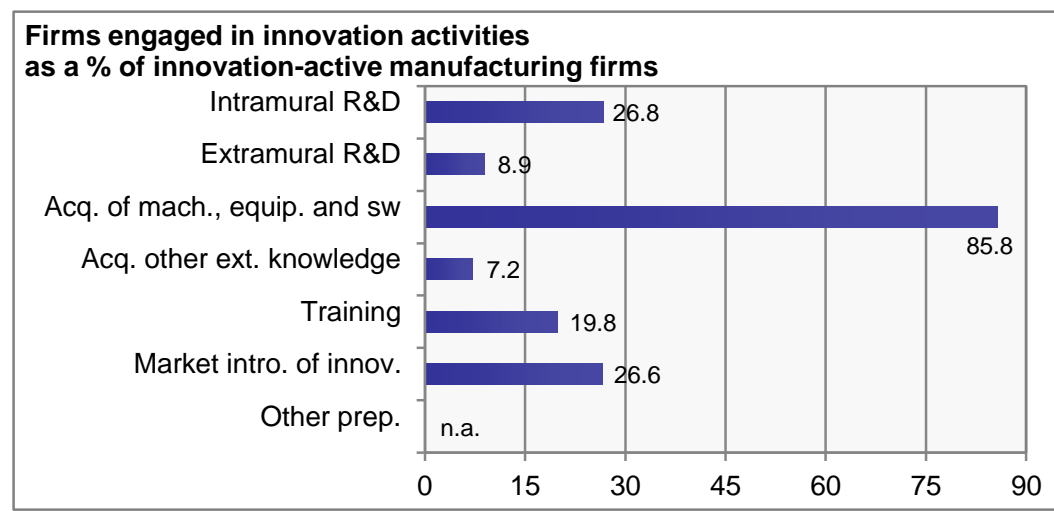

Notes: Data only cover product and process innovators. Acquisition of software is not included. Acquisition of other external knowledge is categorized under technology transfer. 


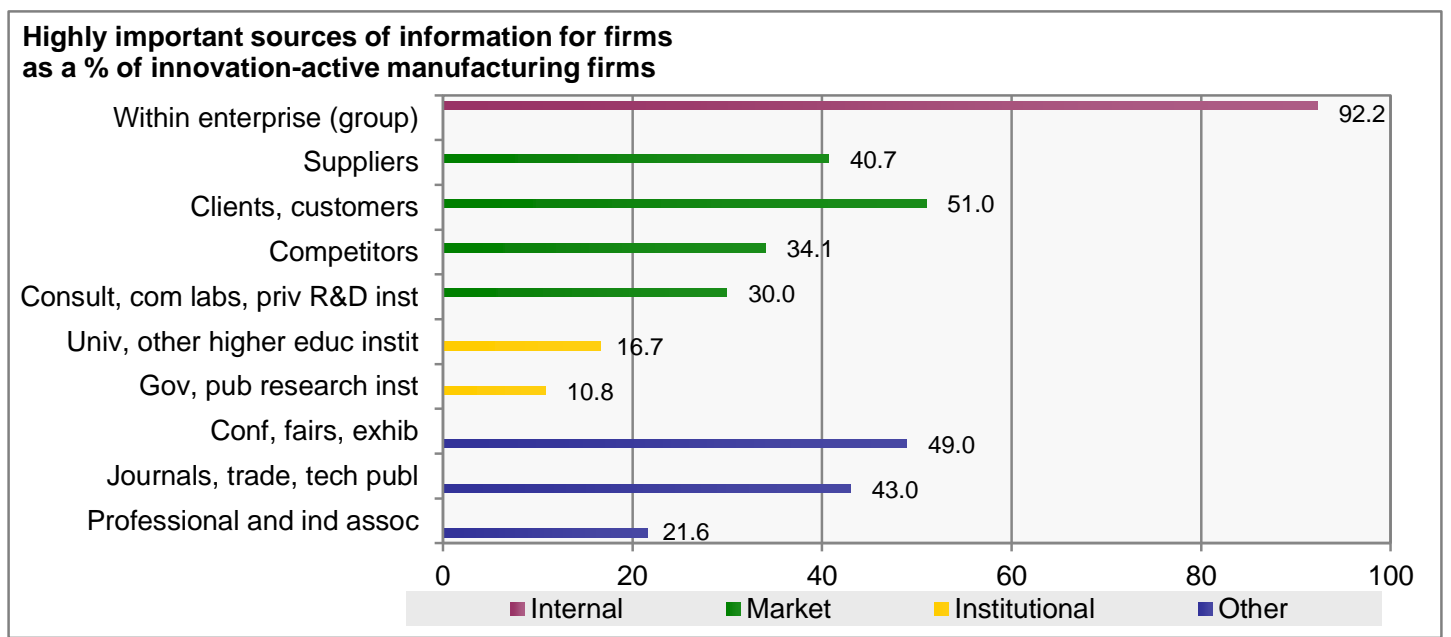

Notes: Data only cover product and process innovators. Question based on dichotomous (yes/no) responses.

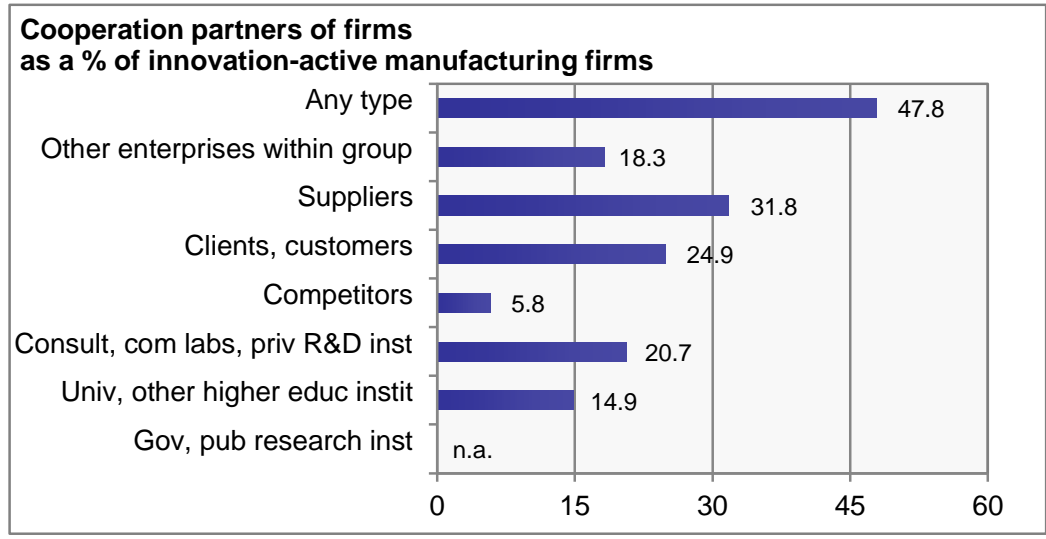

Notes: Data only cover product and process innovators.

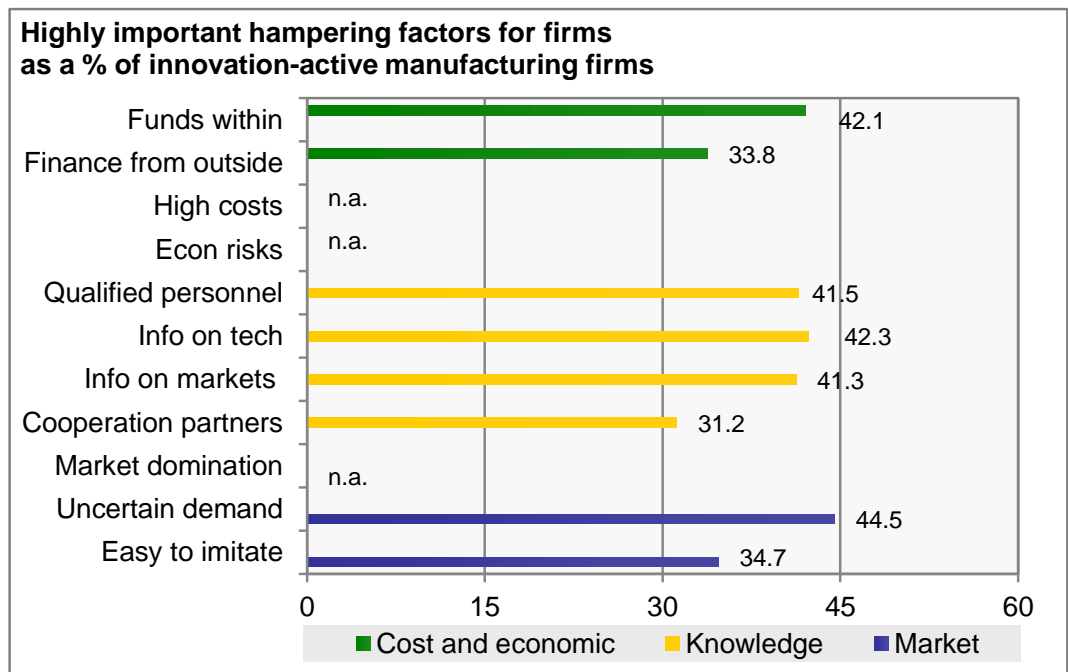

Notes: Data only cover product and process innovators.

General notes: Based on a two-year observation period. Sample survey data (no grossed up results). For more specifications please consult the full report. 


\section{EGYPT AT A GLANCE}

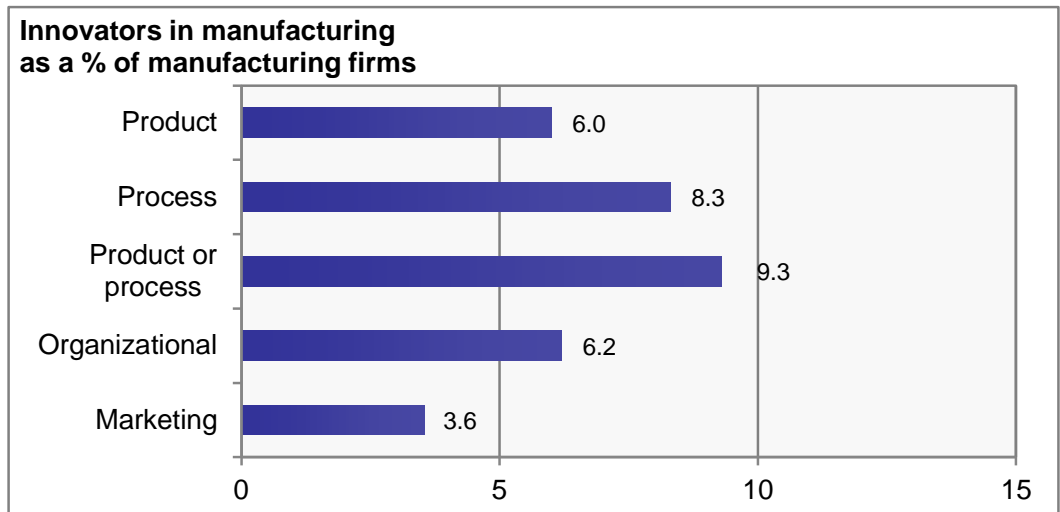

Notes: Organizational innovation includes new or significant changes. Marketing innovation includes significant changes other than in design or packaging.

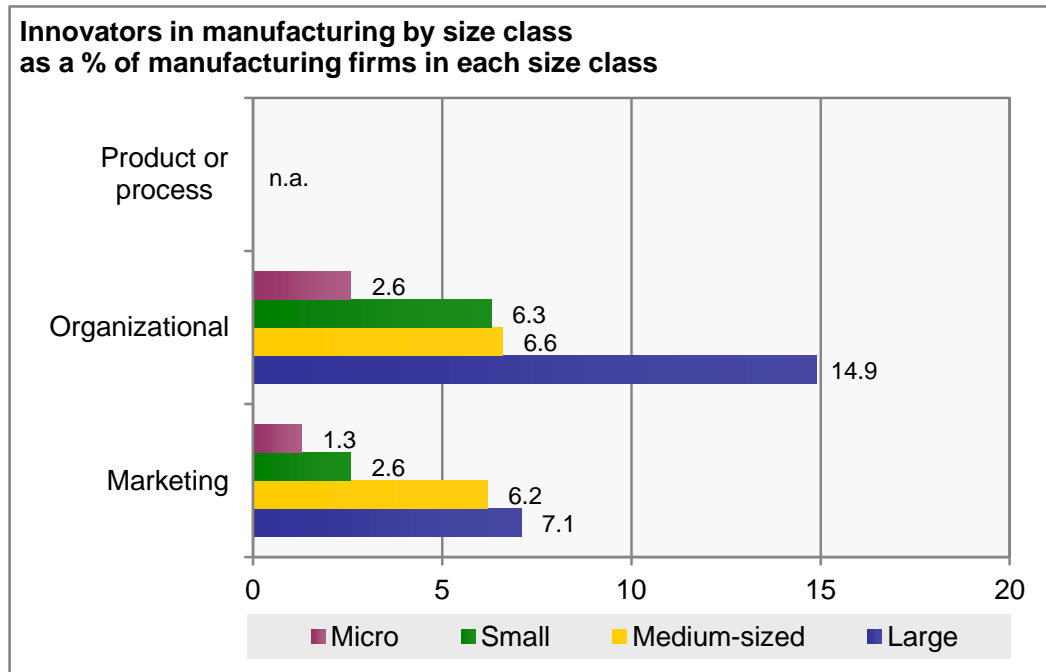

Notes: Organizational innovation includes new or significant changes. Marketing innovation includes significant changes other than in design or packaging.

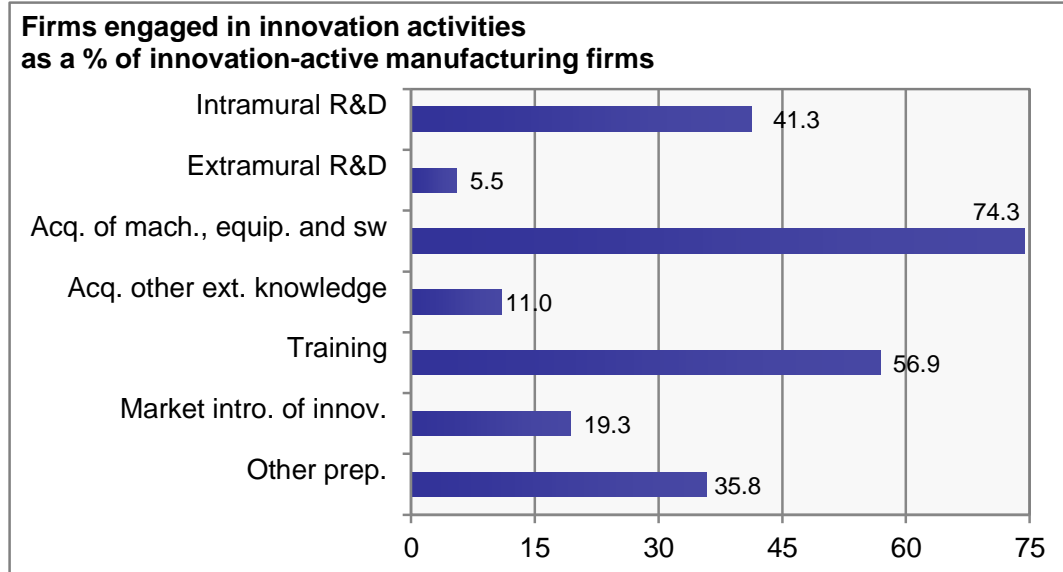



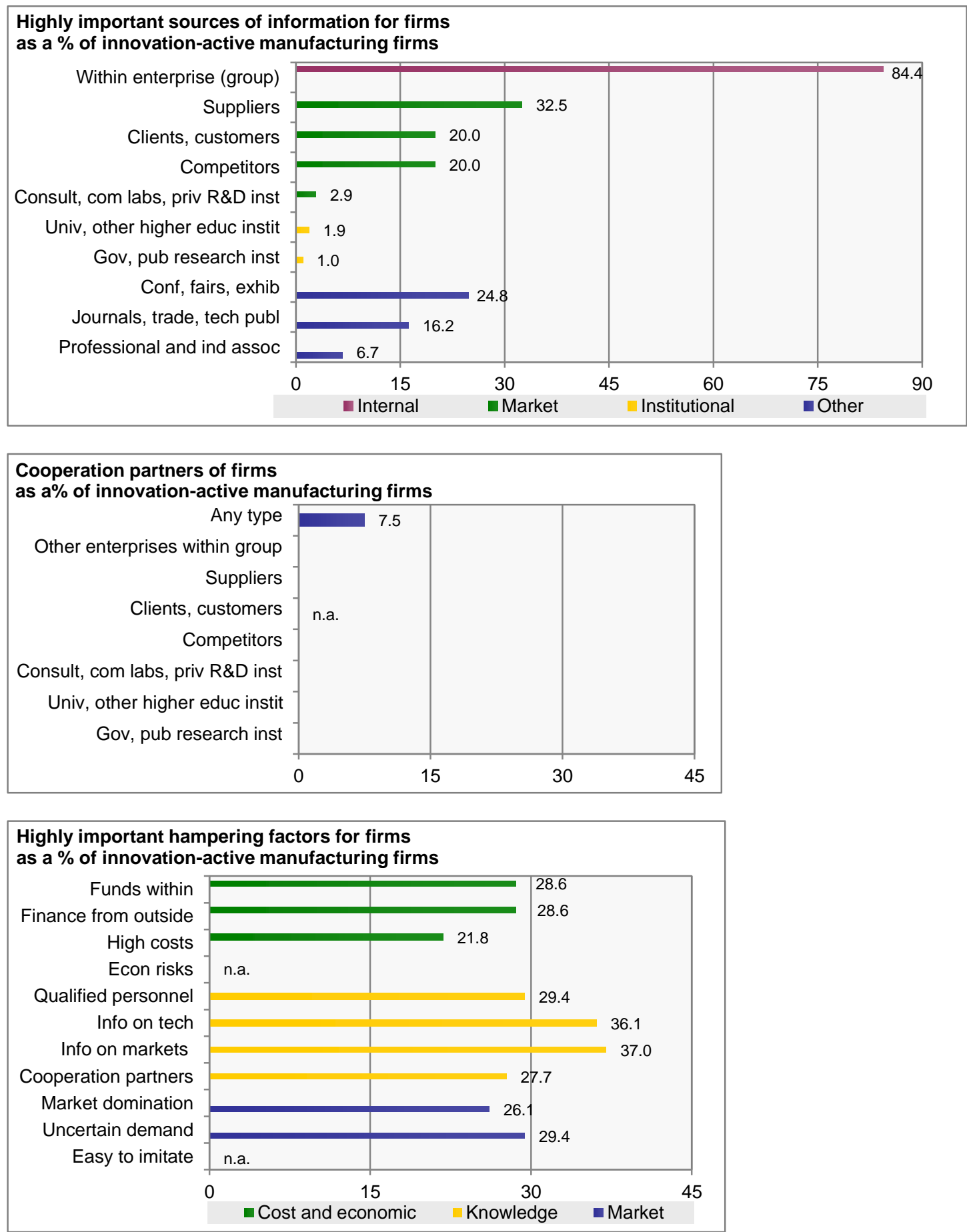

General notes: Based on a three-year observation period. For more specifications please consult the full report. 


\section{GHANA AT A GLANCE}

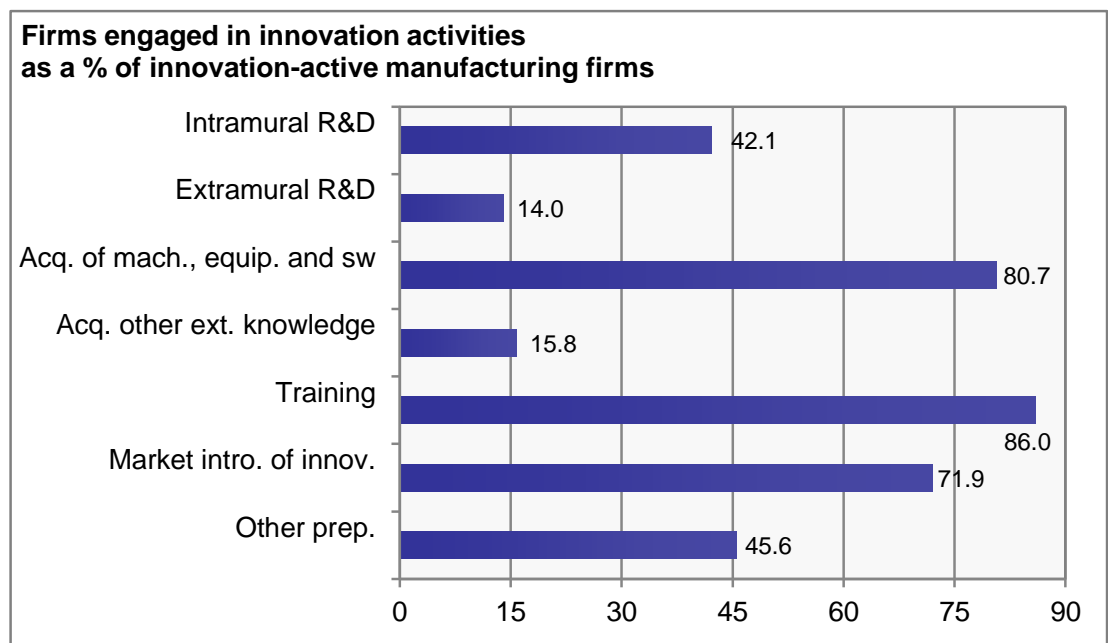

Notes: Data only cover product and process innovators.

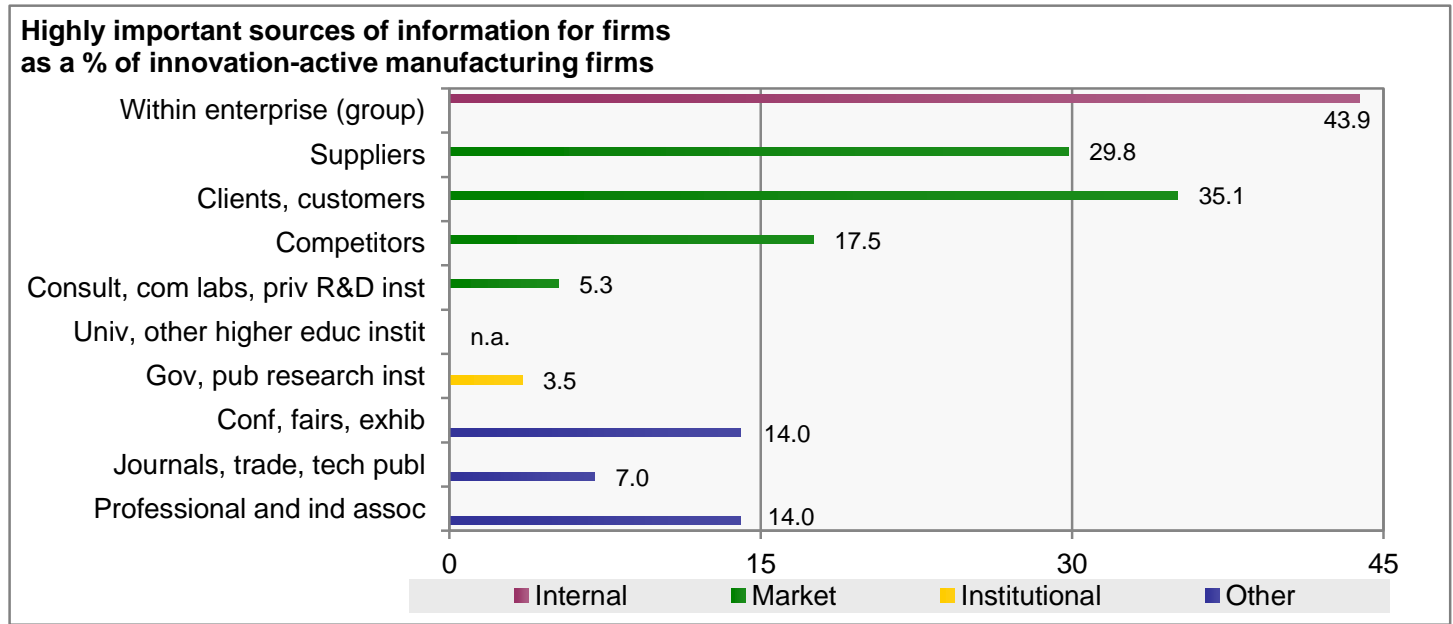

Notes: Data only cover product and process innovators.

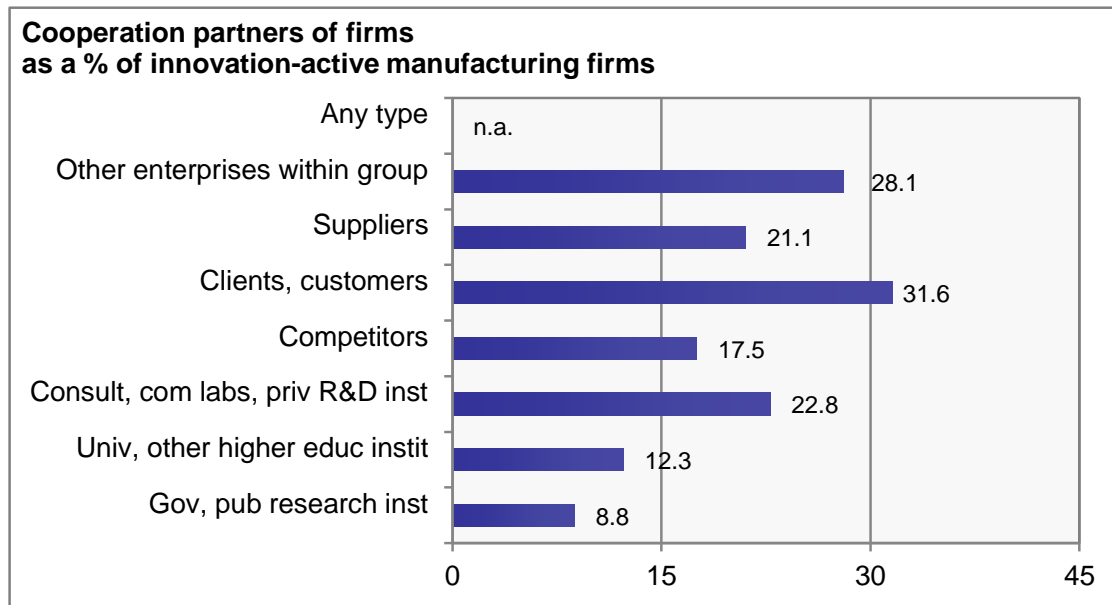

Notes: Data only cover product and process innovators. 


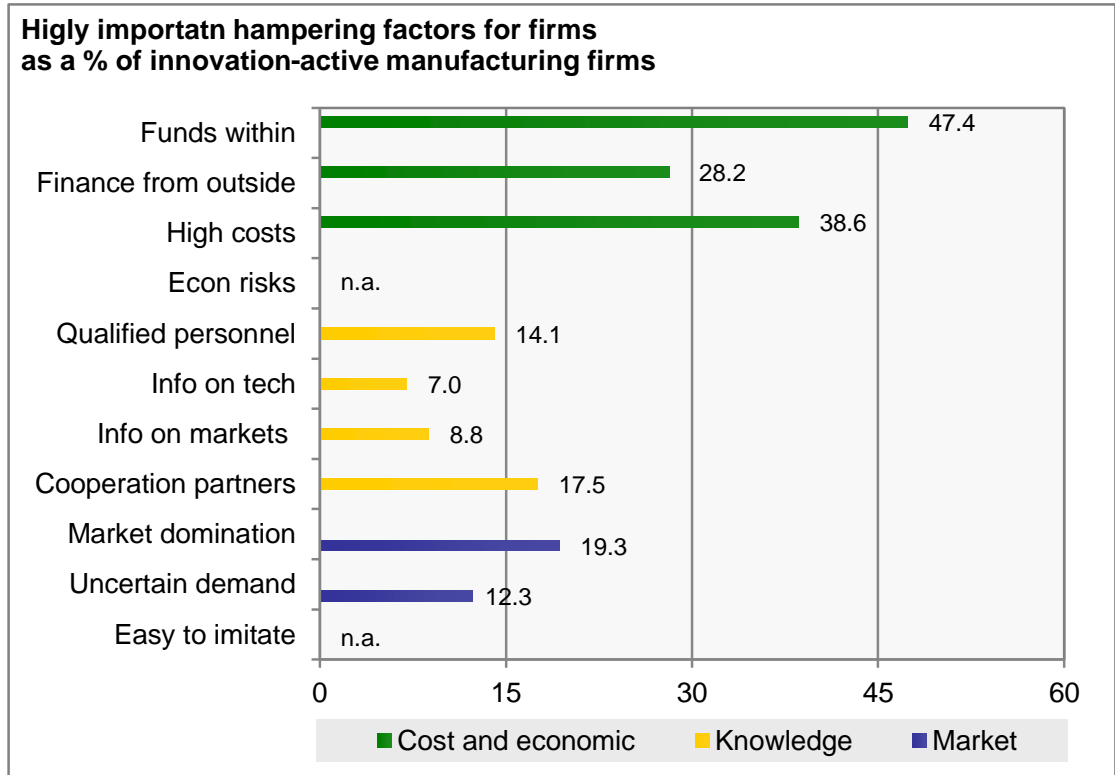

Notes: Data only cover product and process innovators.

General notes: Based on a three-year observation period. For more specifications please consult the full report. 


\section{INDONESIA AT A GLANCE}

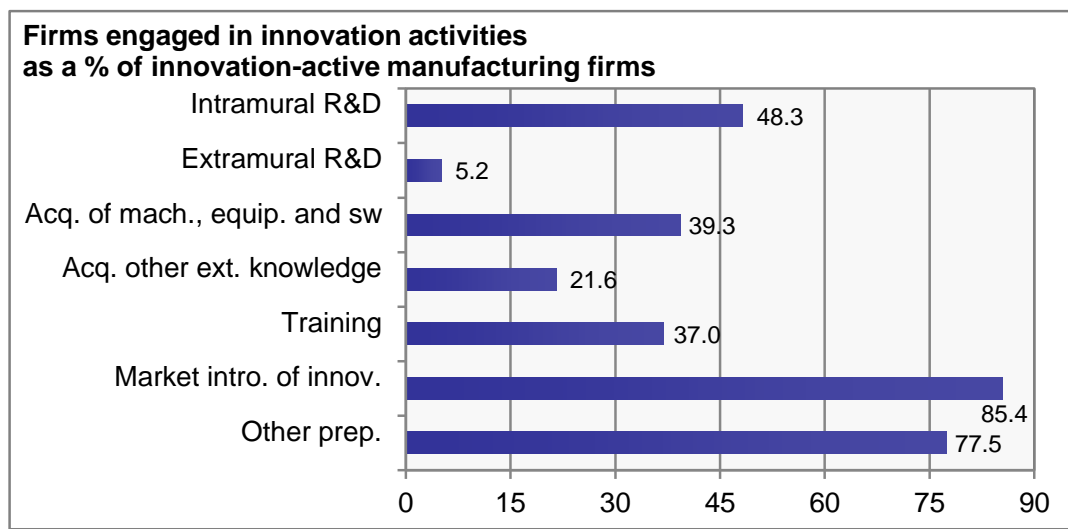

Notes: No specification of firms covered.

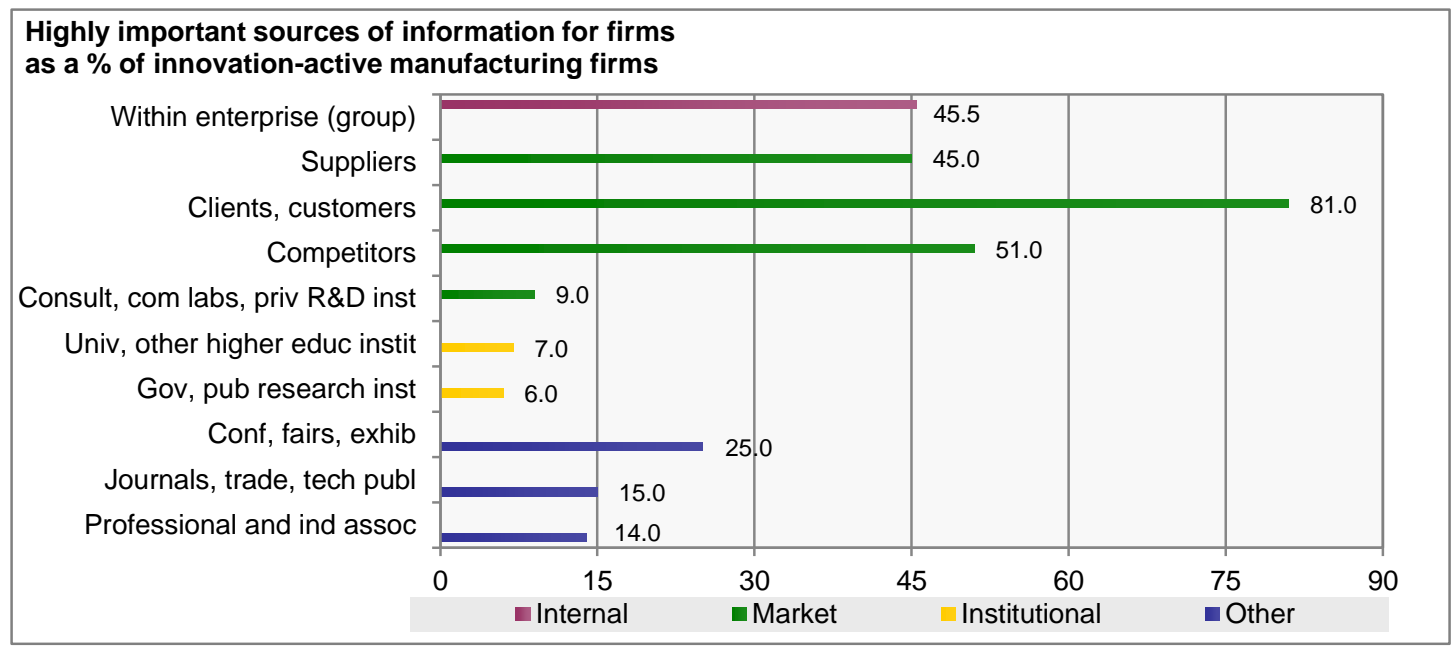

Notes: No specification of firms covered.

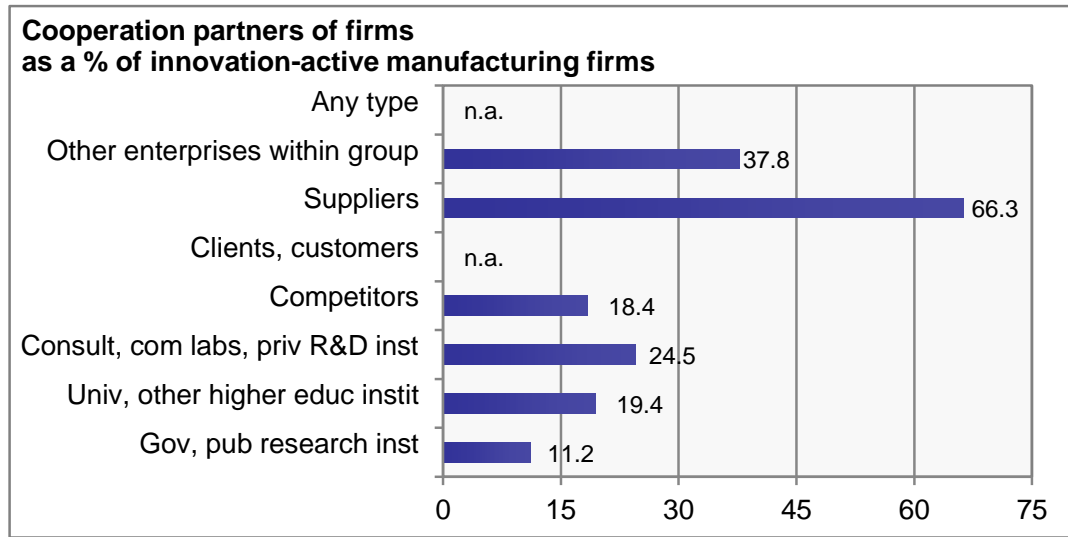

Notes: No specification of firms covered. 


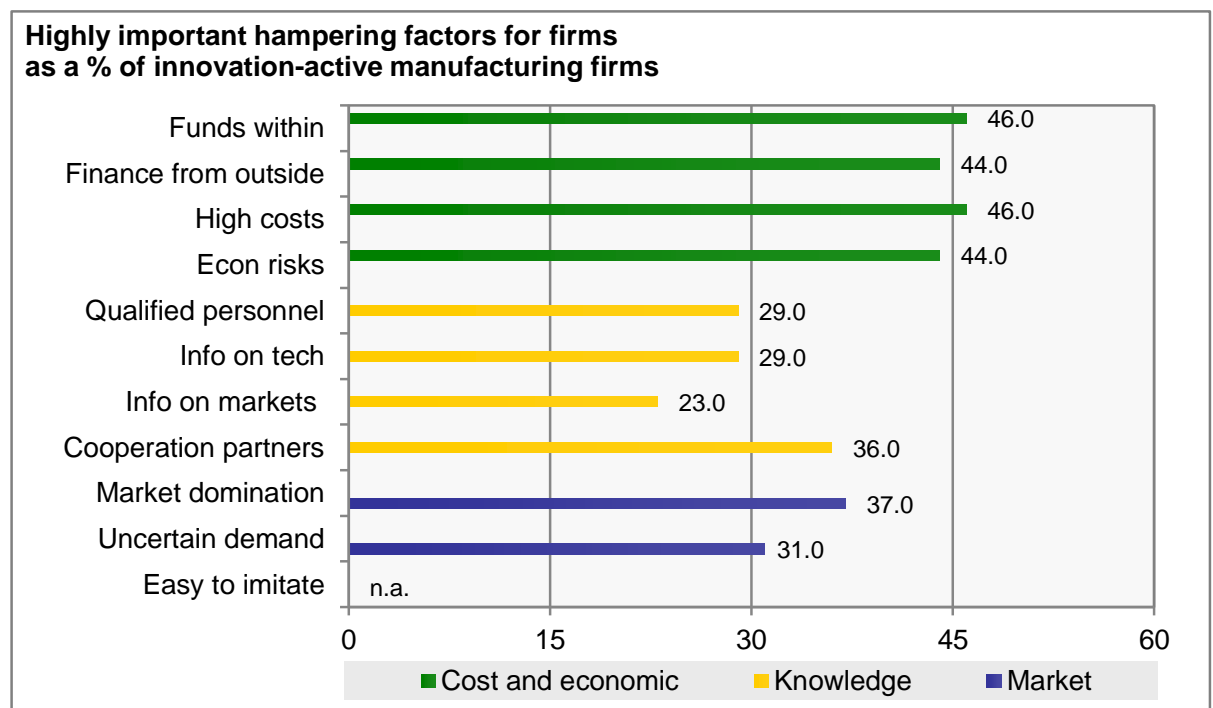

General notes: Based on a two-year observation period. For more specifications please consult the full report. 


\section{ISRAEL AT A GLANCE}
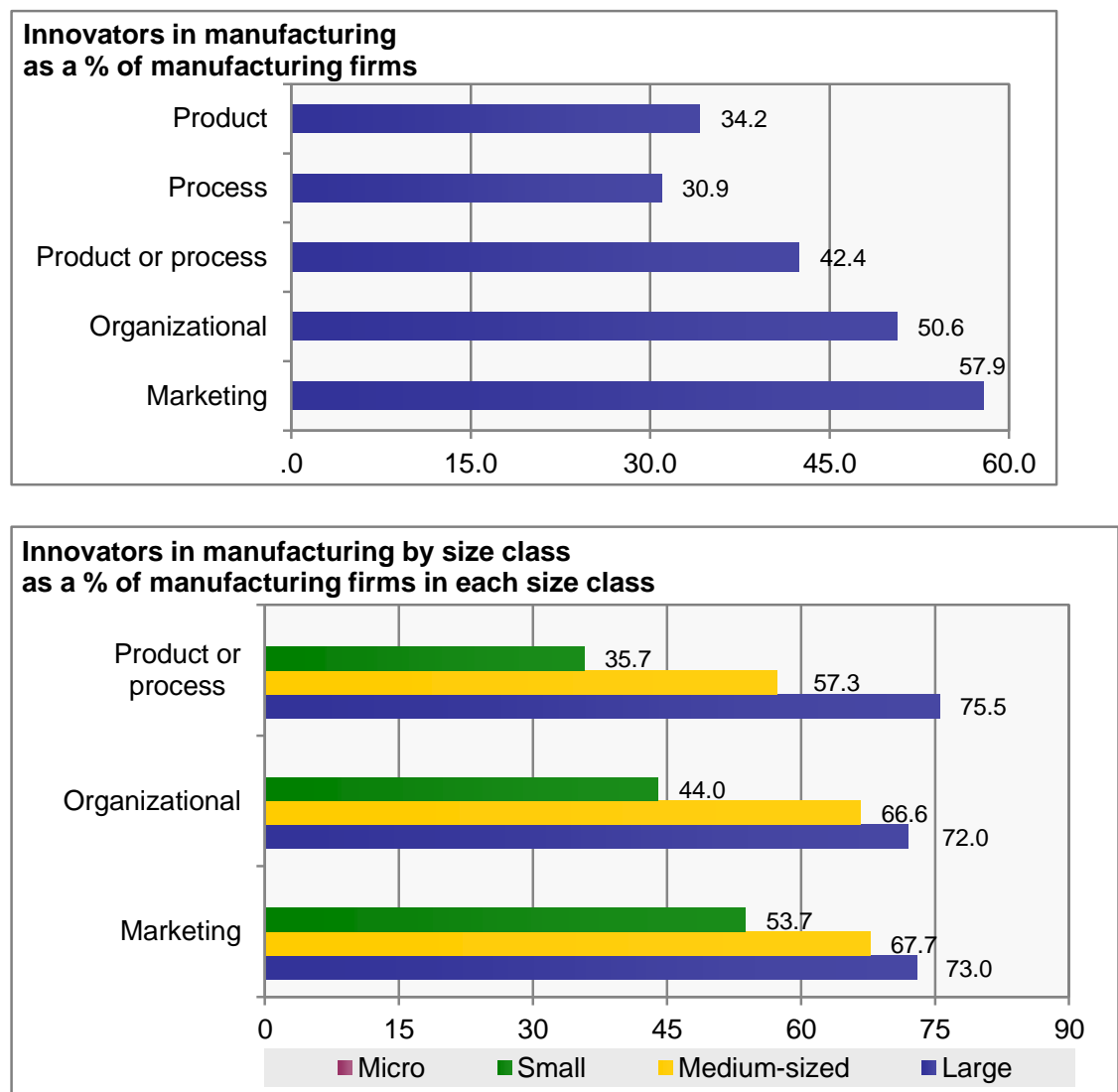

Firms engaged in innovation activities

as a $\%$ of innovation-active manufacturing firms

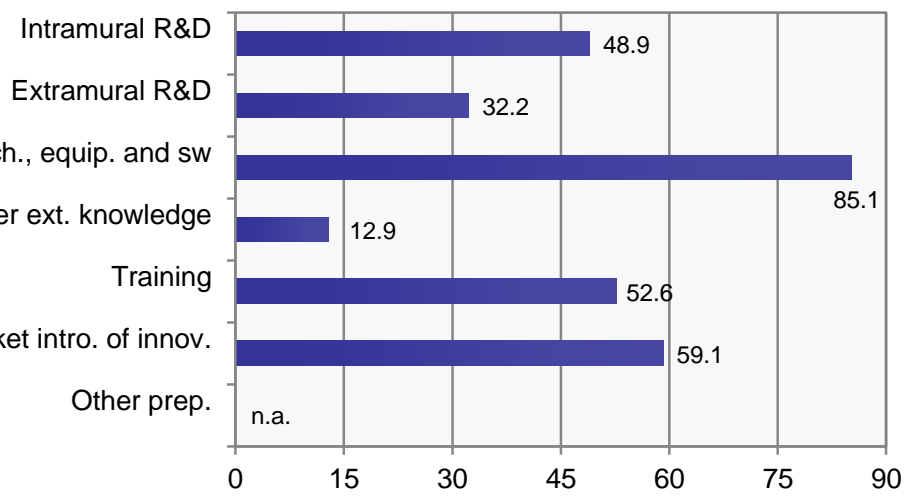



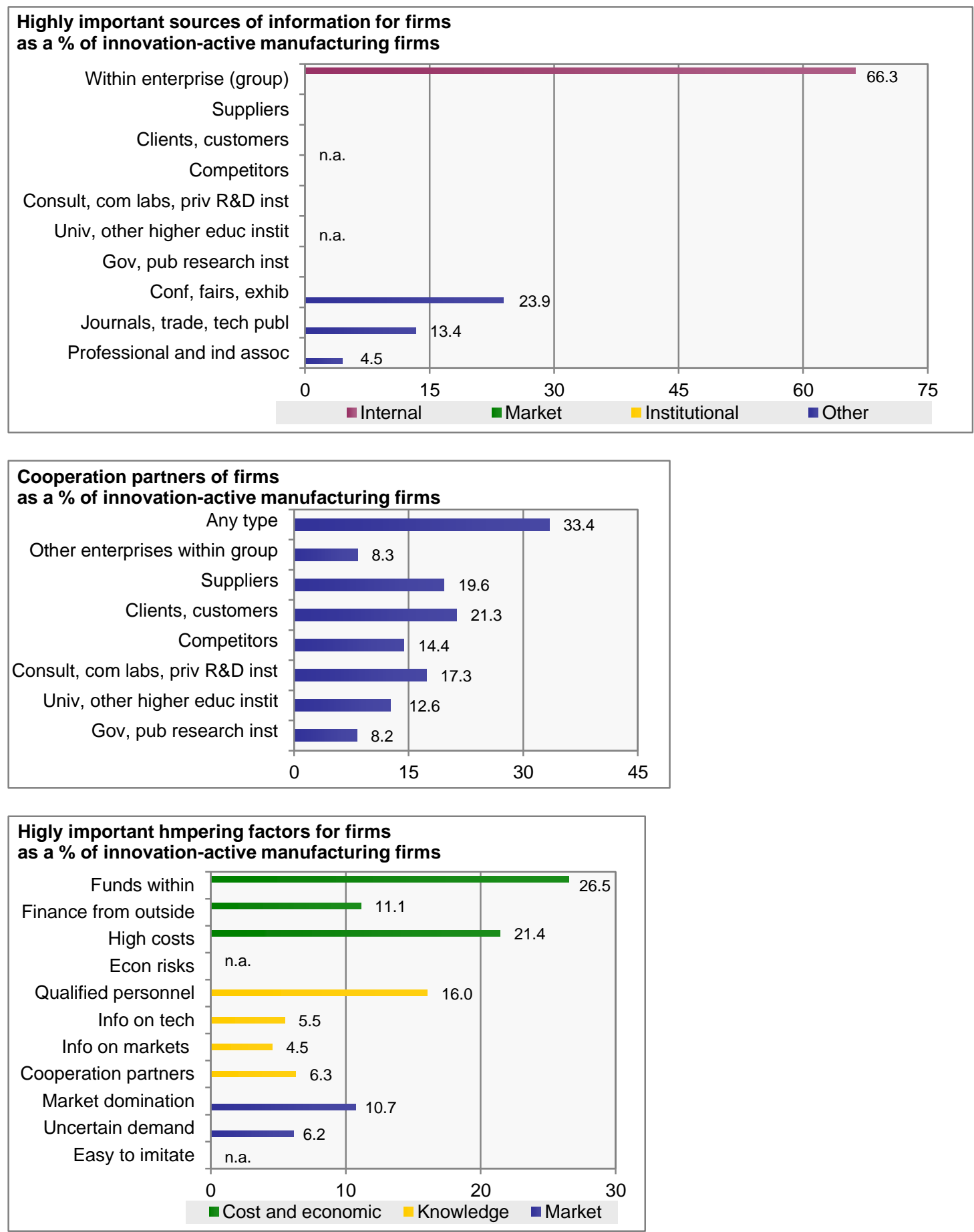

General notes: Based on a three-year observation period. For more specifications please consult the full report. 


\section{MALAYSIA AT A GLANCE}

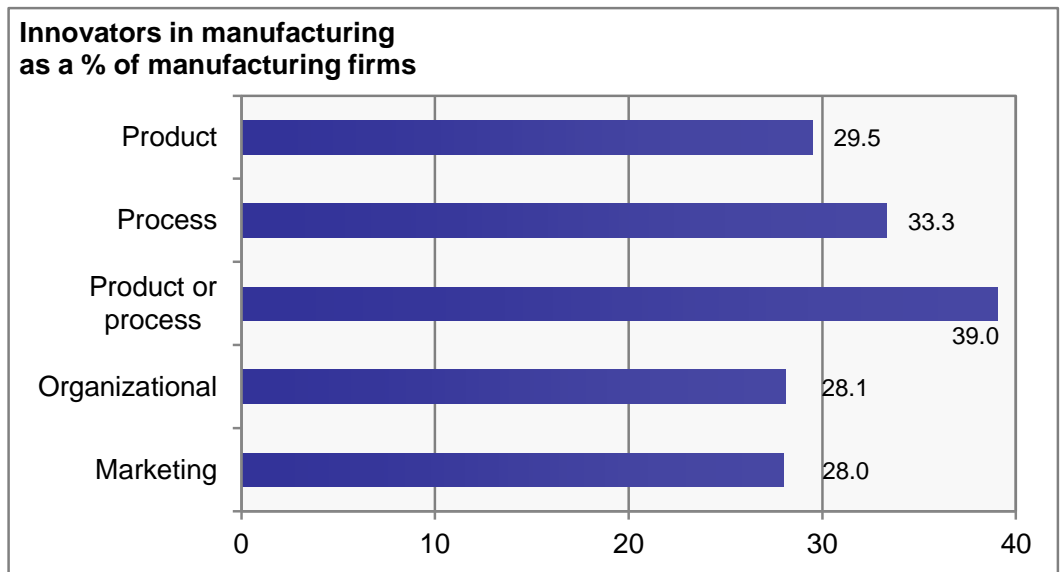

Notes: Organizational innovation includes new or significant changes. Marketing innovation includes significant changes other than in design or packaging.

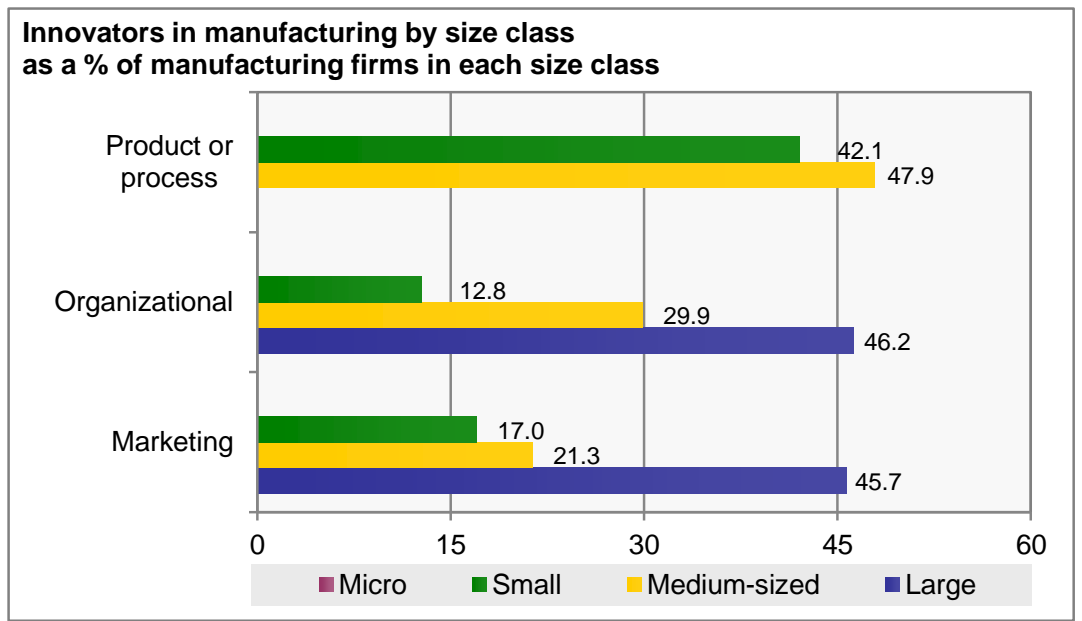

Notes: Organizational innovation includes new or significant changes. Marketing innovation includes significant changes other than in design or packaging.

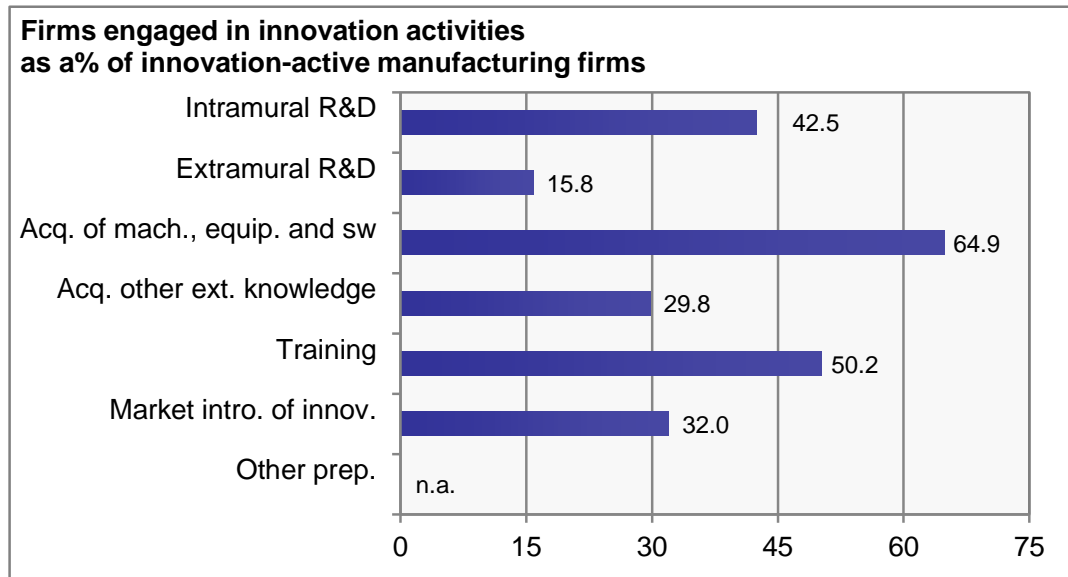

Notes: Data also cover organizational and marketing innovators. 


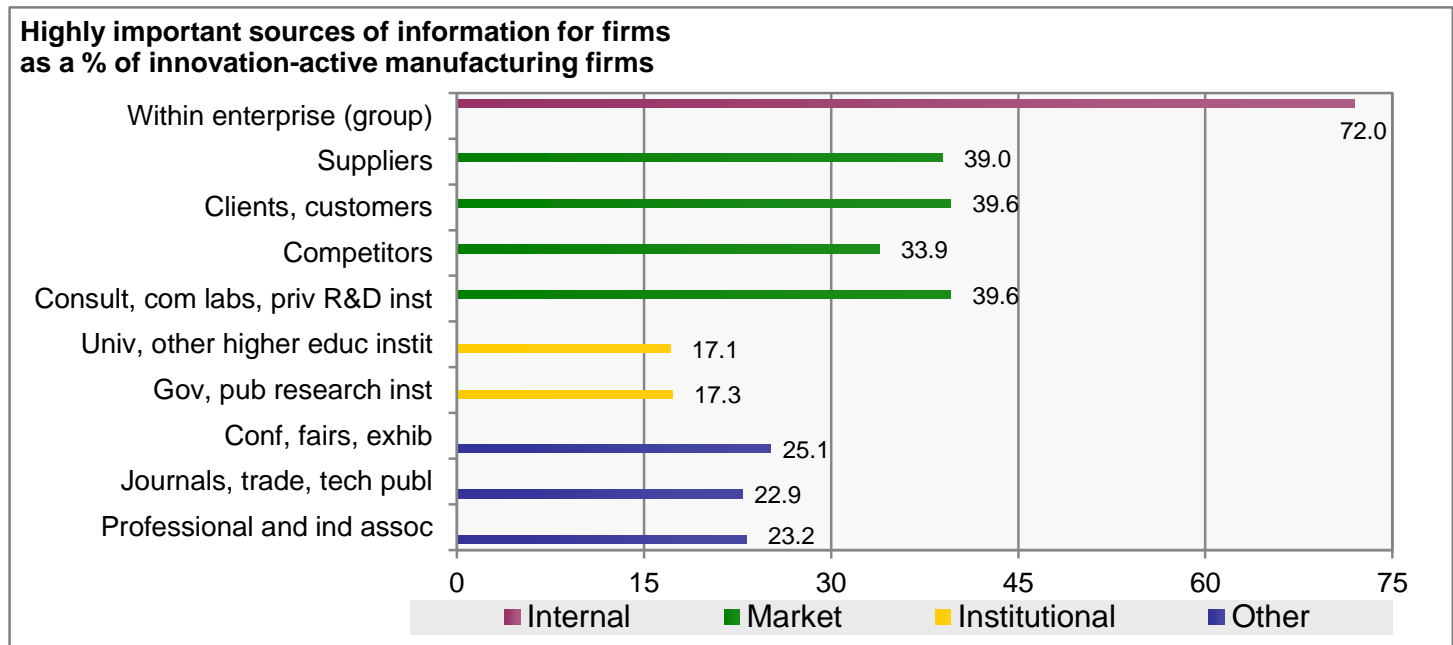

Notes: Data also cover organizational and marketing innovators.

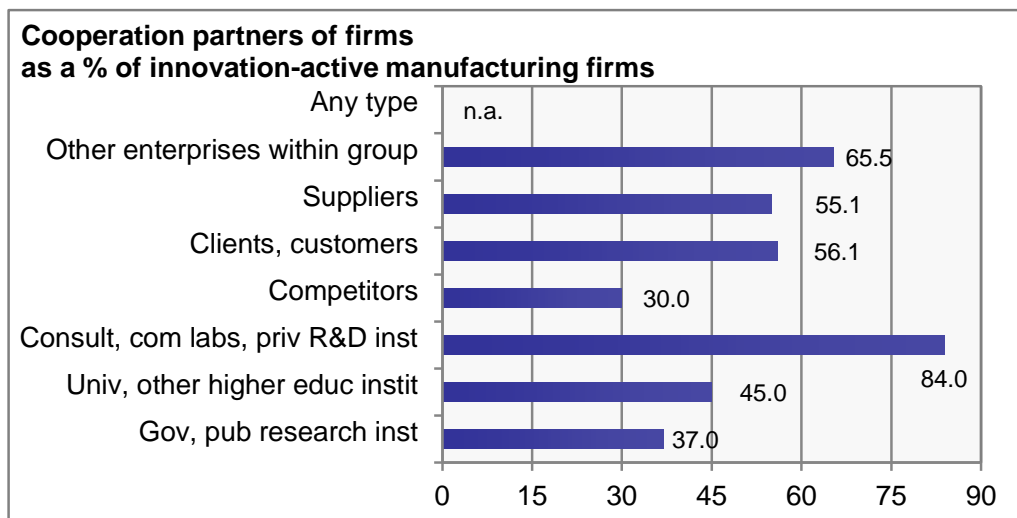

Notes: Data also cover organizational and marketing innovators.

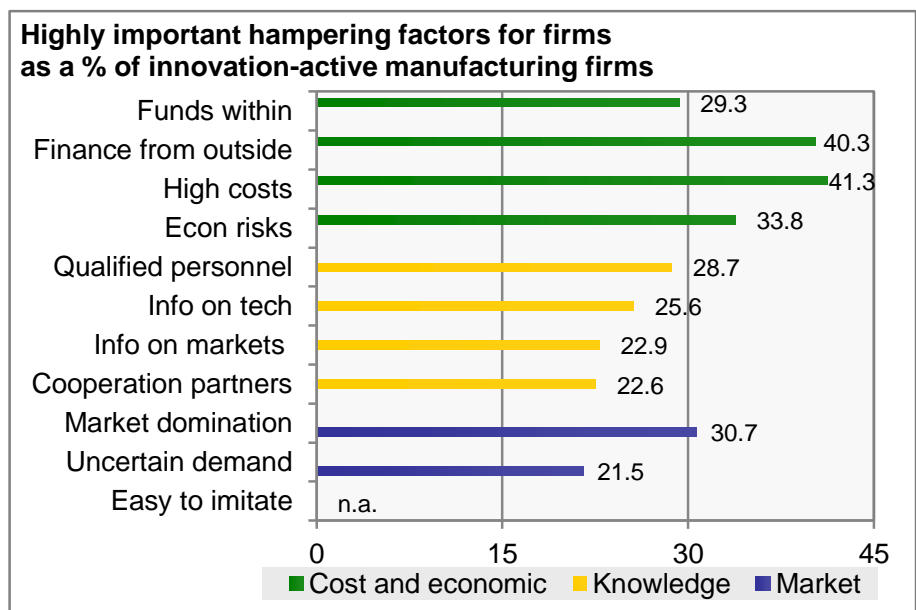

Notes: Data also cover organizational and marketing innovators.

General notes: Based on a four-year observation period. For more specifications please consult the full report. 


\section{PHILIPPINES AT A GLANCE}

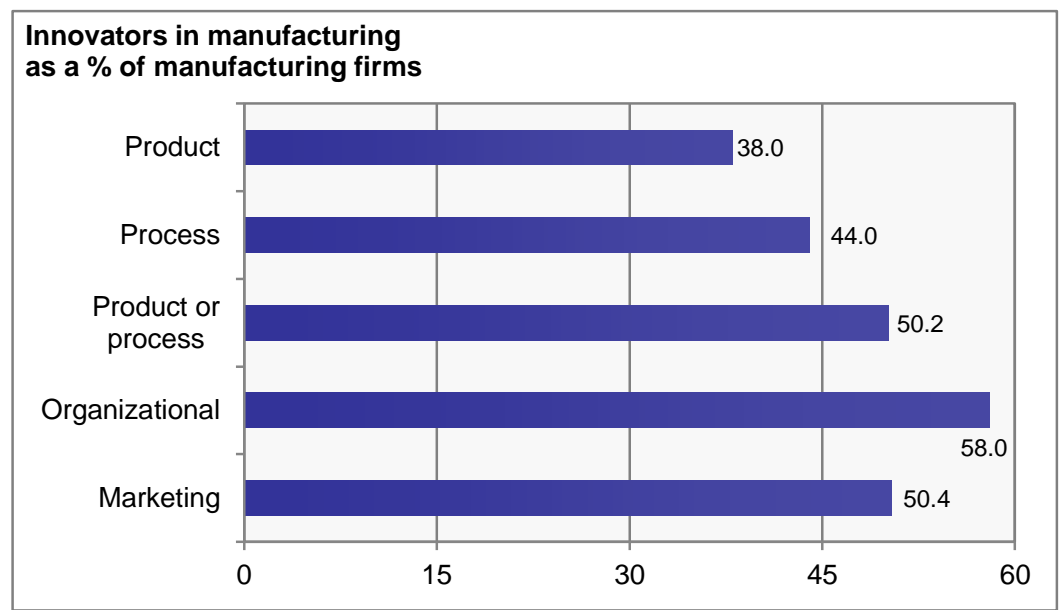

Notes: Organizational innovation includes new or significant changes.

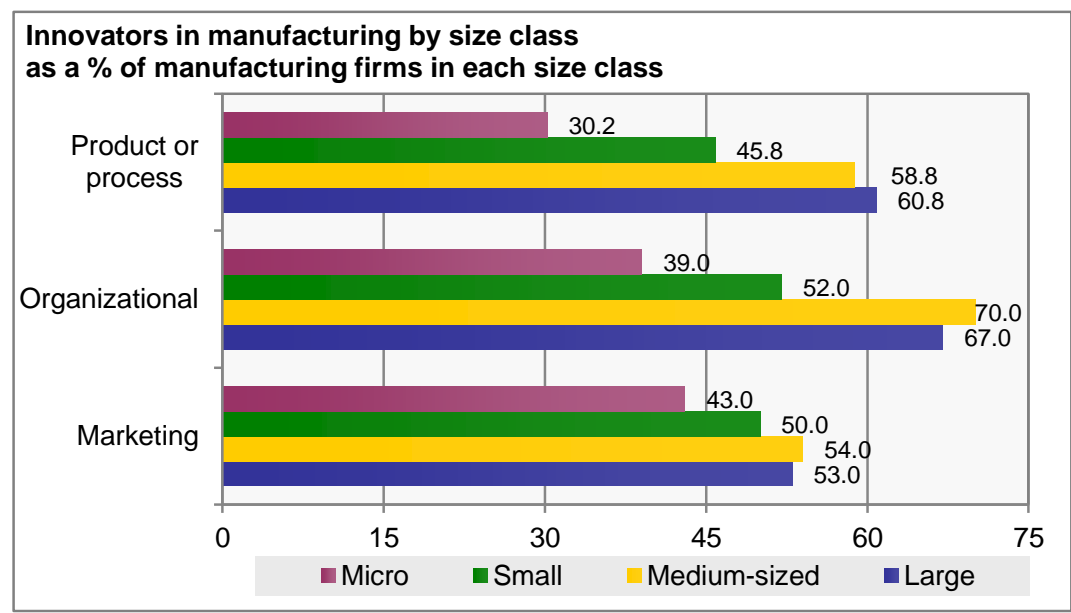

Notes: Organizational innovation includes new or significant changes.

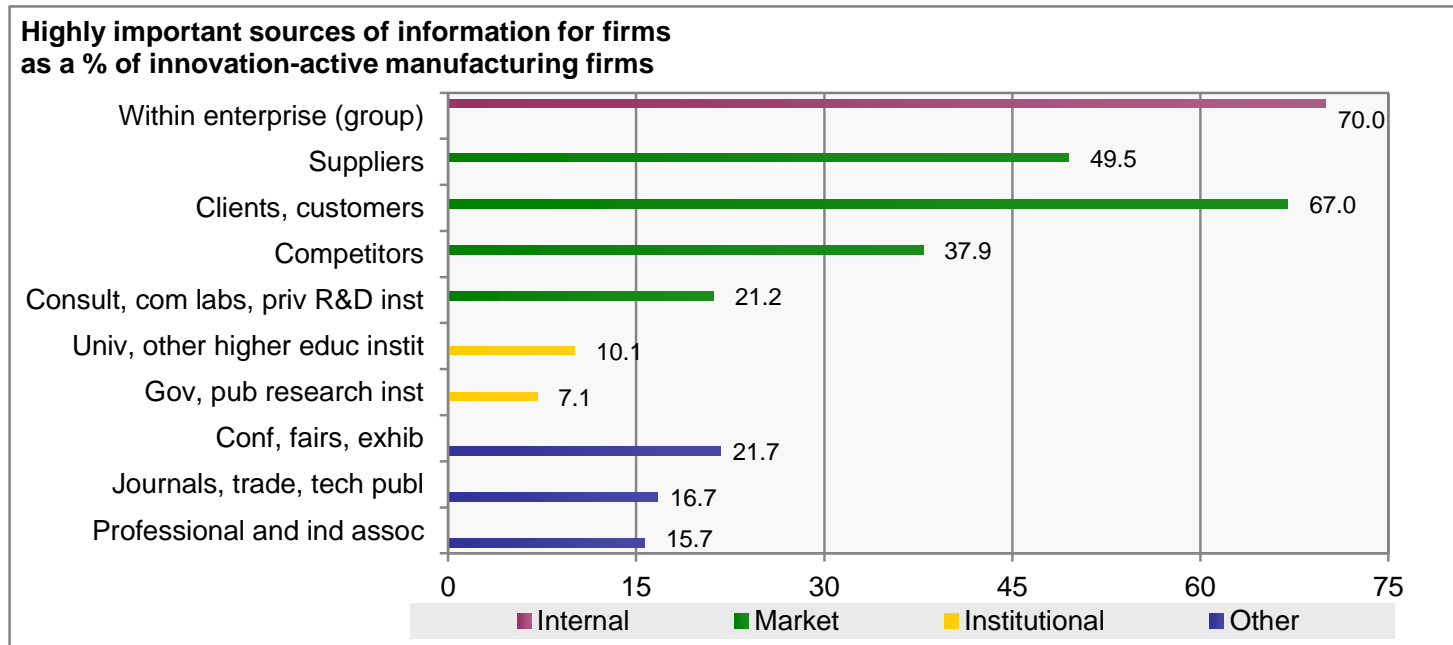



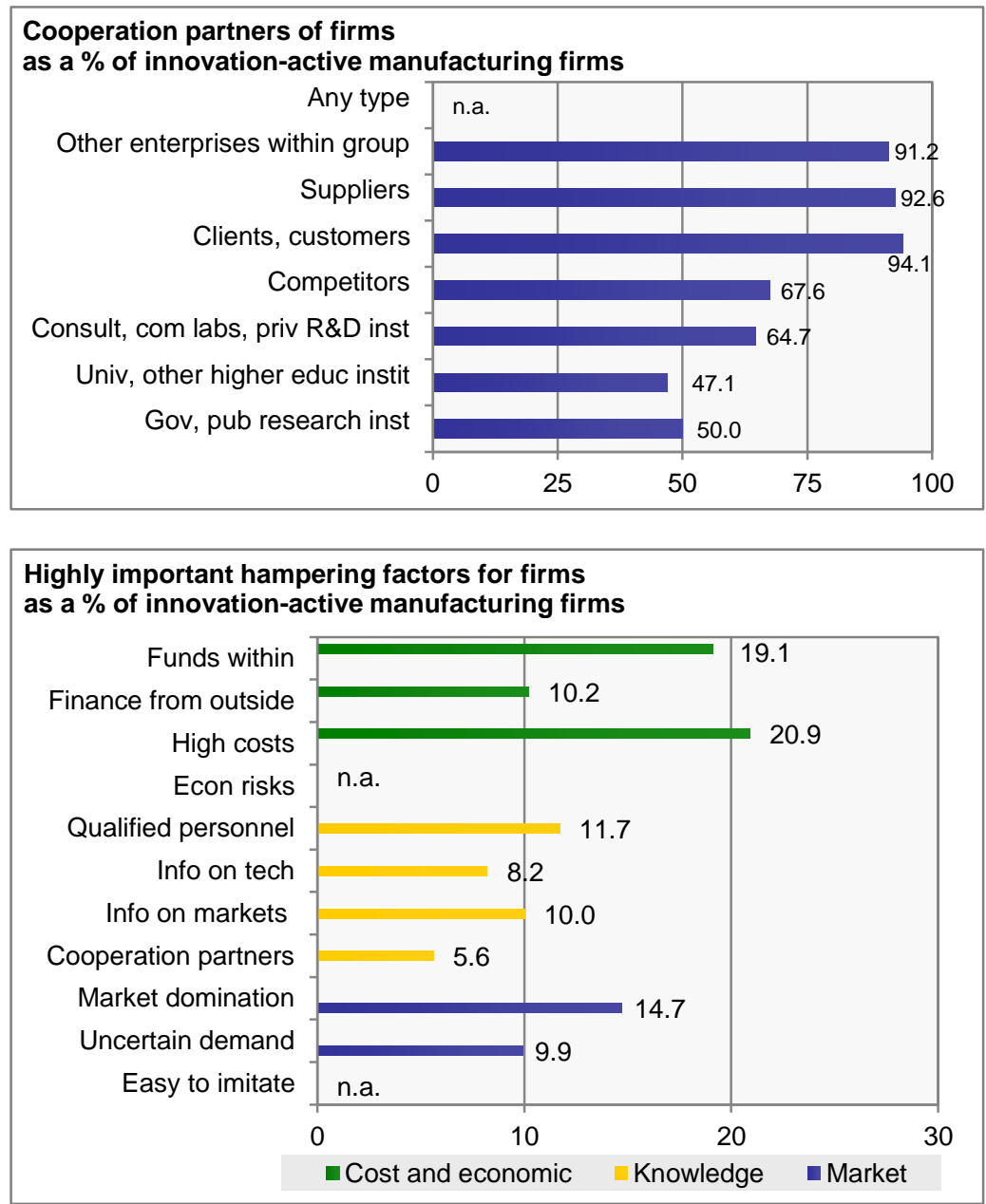

General notes: Based on a one-and-a-half-year observation period. IT services are also included. Results are not representative of the target population. For more specifications please consult the full report. 


\section{RUSSIAN FEDERATION AT A GLANCE}
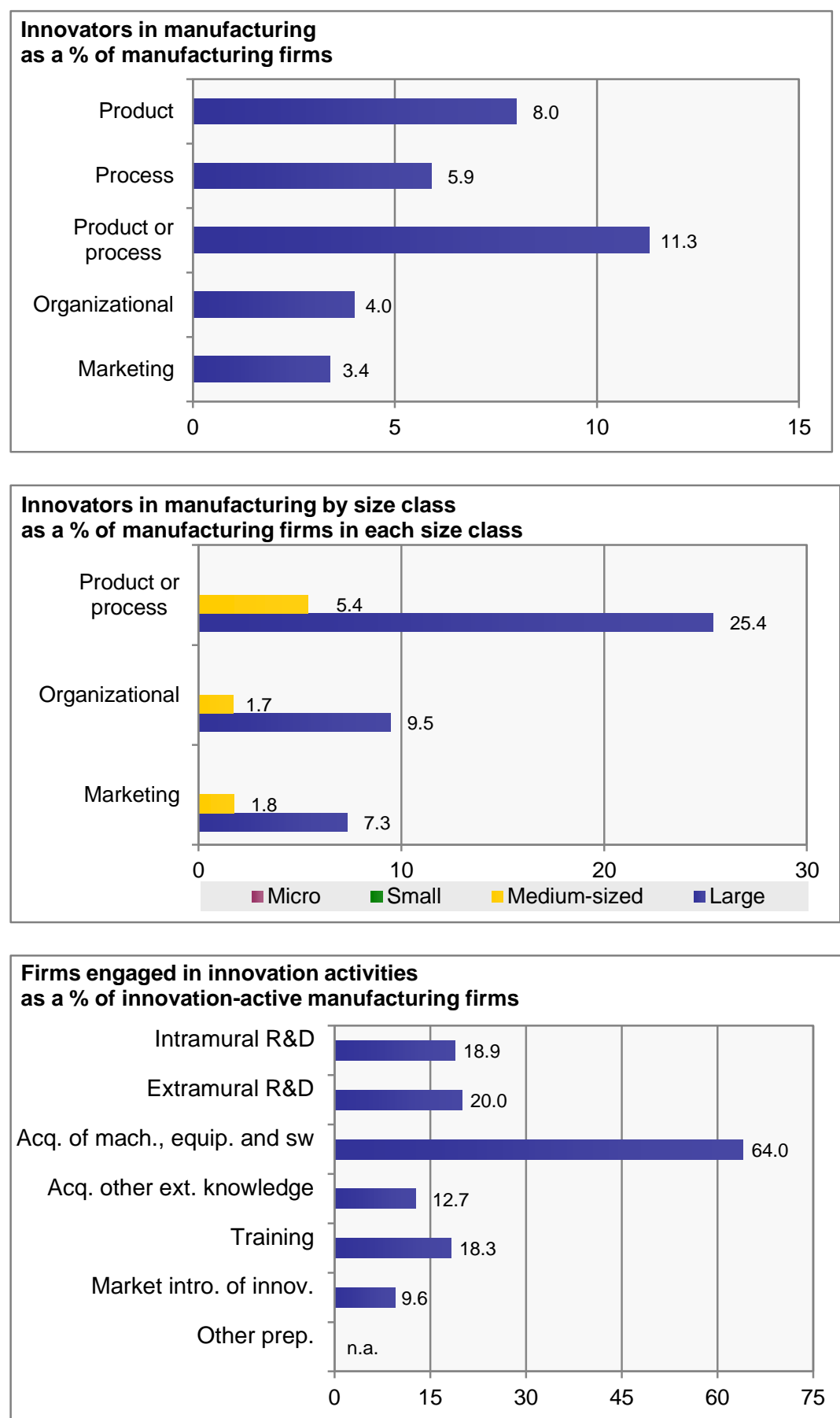

Notes: Acquisition of software is not included. 


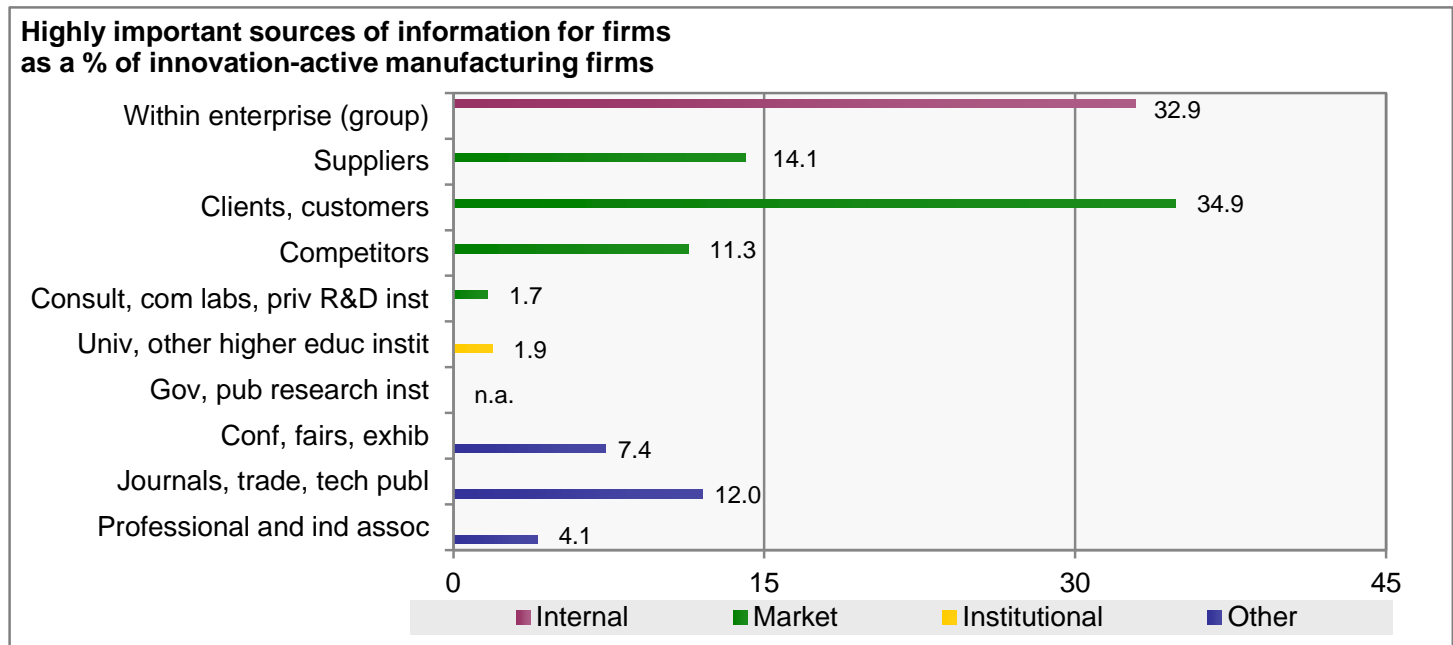

Notes: Data also cover organizational and marketing innovators. Internal sources do not cover enterprise group.

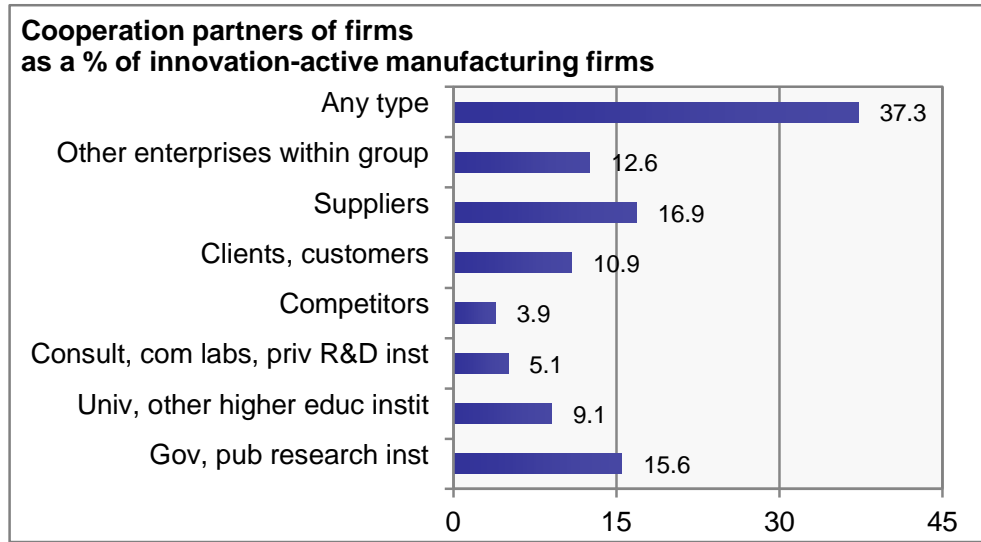

Notes: Data also cover organizational and marketing innovators.

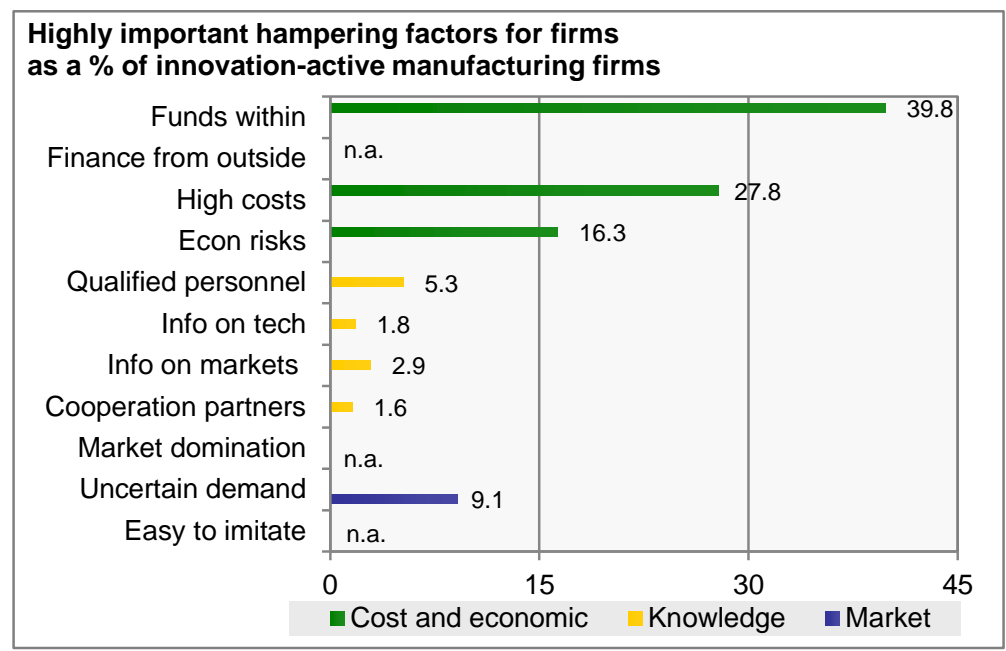

Notes: Data also cover organizational and marketing innovators.

General notes: Based on a one-year observation period. For more specifications please consult the full report. 


\section{SOUTH AFRICA AT A GLANCE}

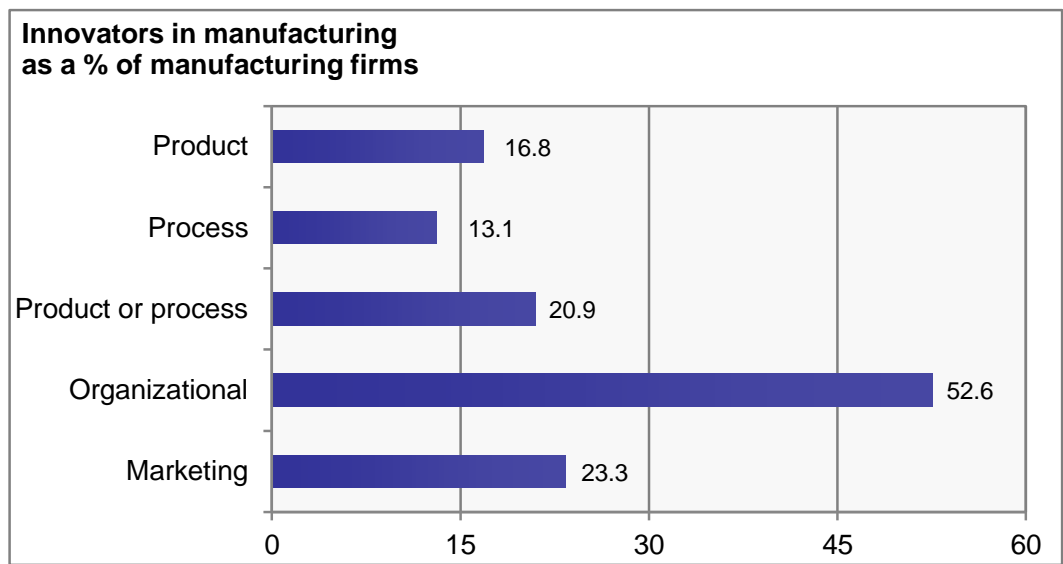

Notes: Organizational innovation includes new or significant changes. Marketing innovation includes significant changes other than in design or packaging.

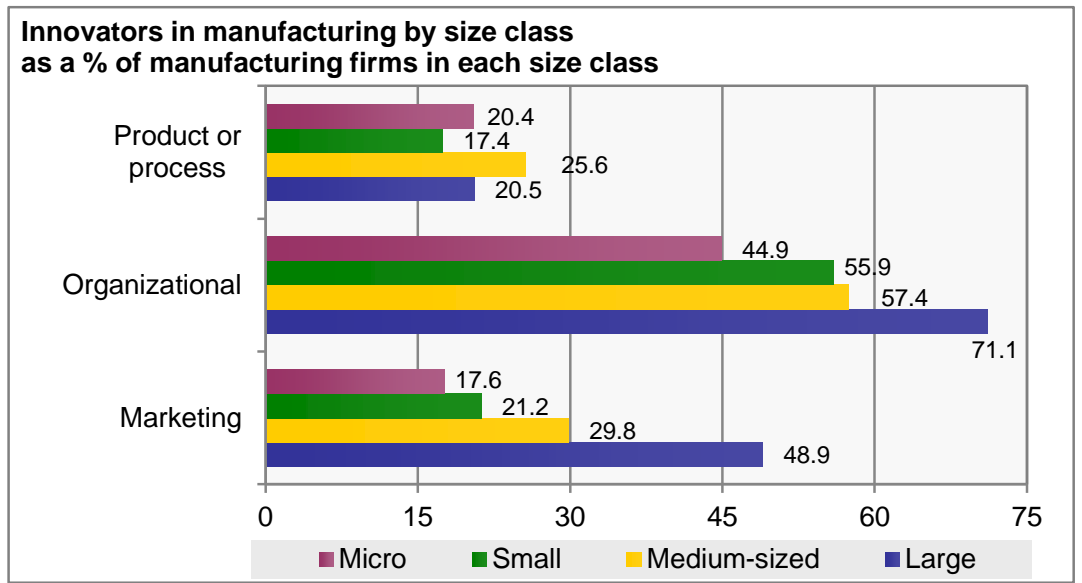

Notes: Organizational innovation includes new or significant changes. Marketing innovation includes significant changes other than in design or packaging.

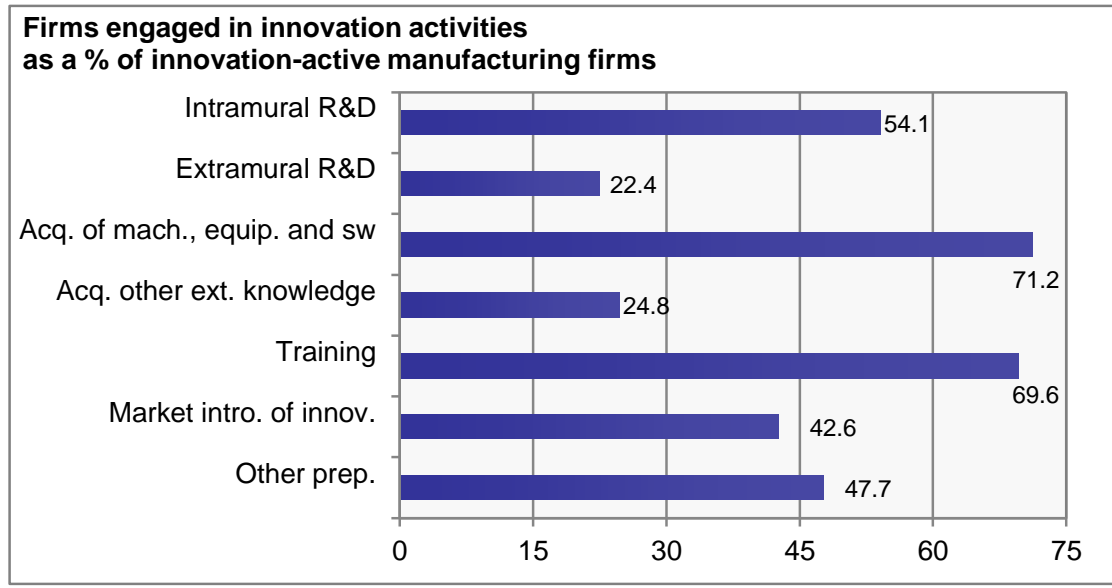



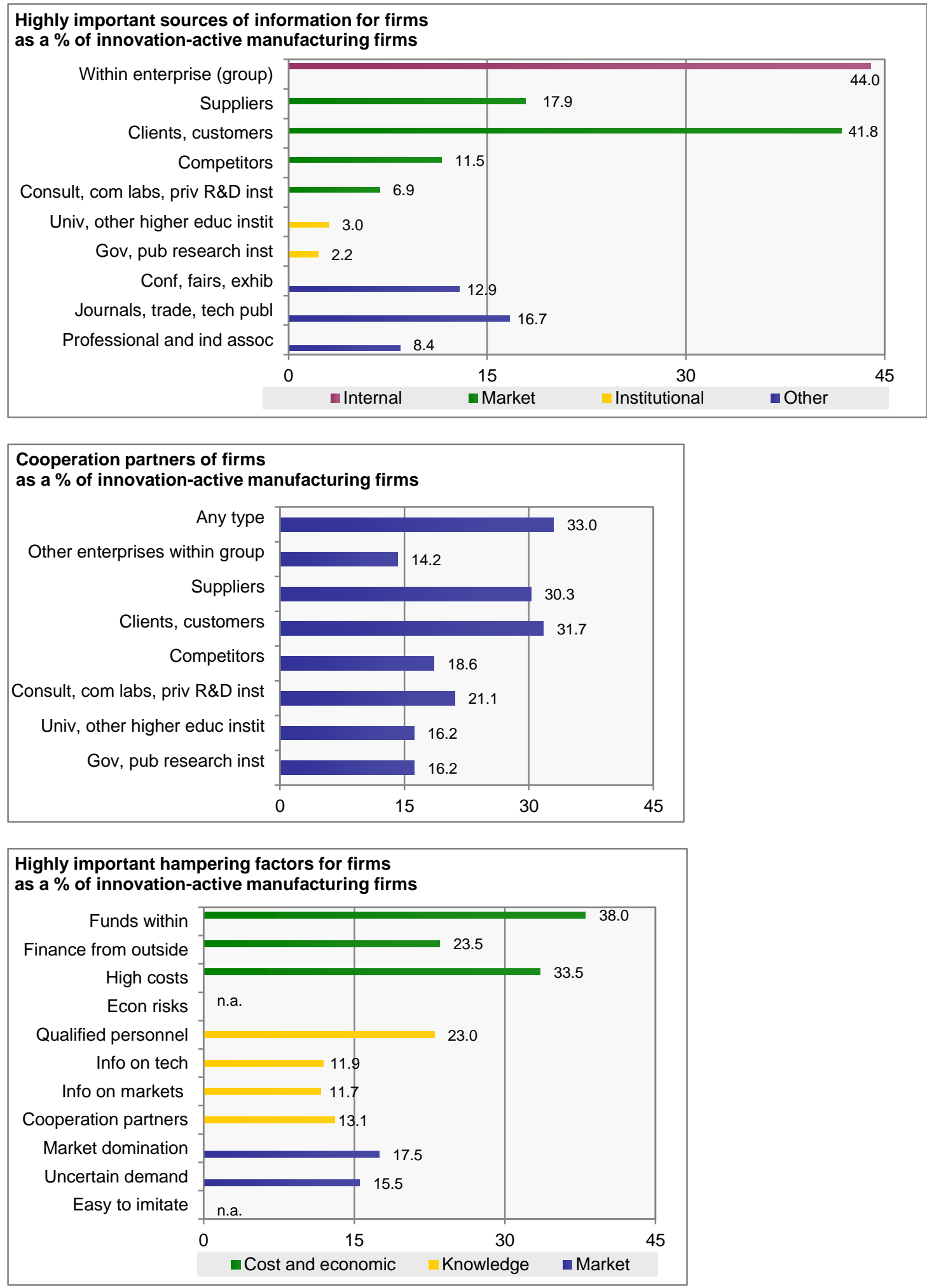

General notes: Based on a three-year observation period. For more specifications please consult the full report. 


\section{URUGUAY AT A GLANCE}
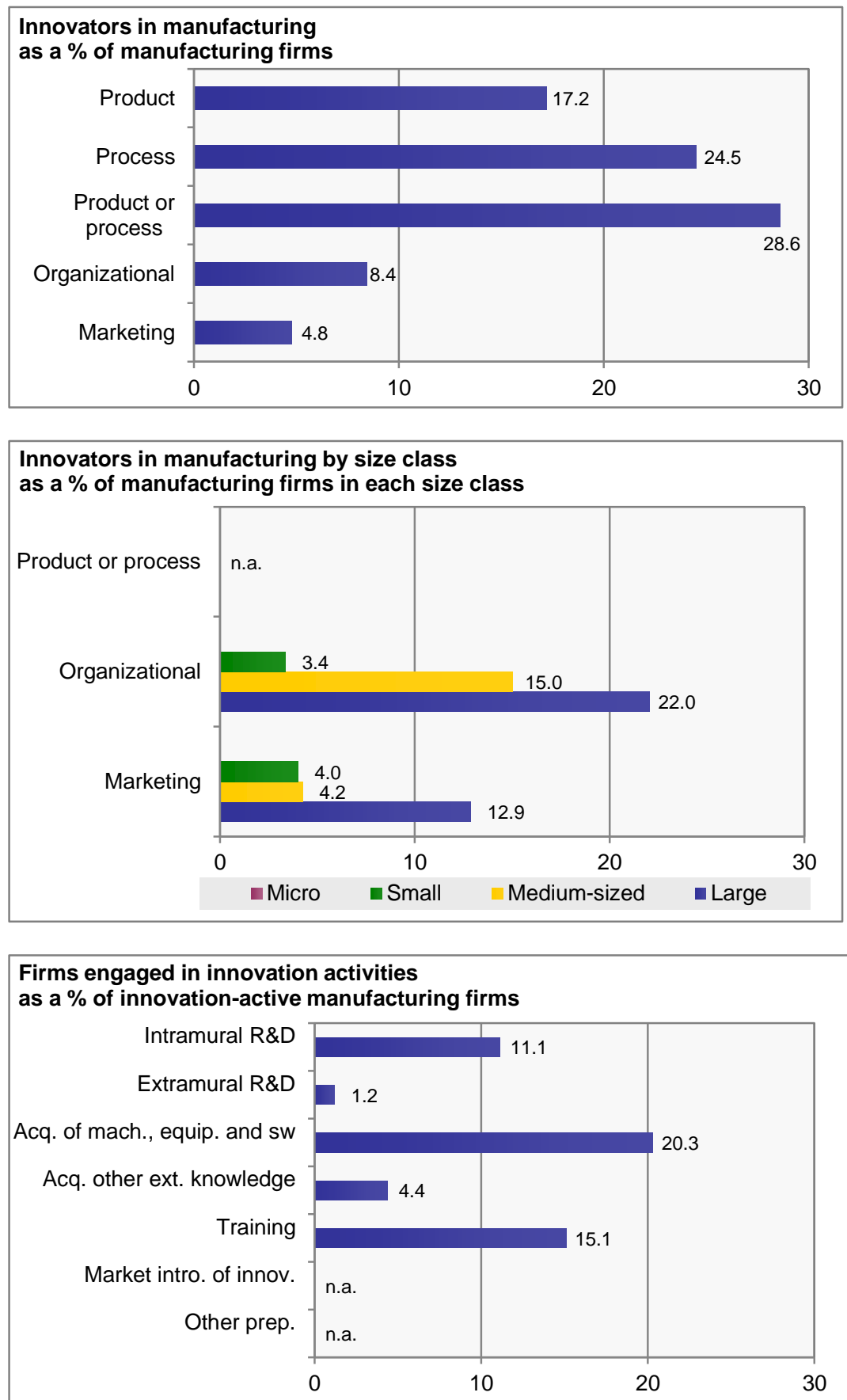

Notes: Data cover organizational and marketing innovators and exclude firms with abandoned or ongoing activities. Acquisition of machinery, equipment and software refers to acquisition of capital goods. Acquisition of other external knowledge is categorized under technology transfer and consultancy. 


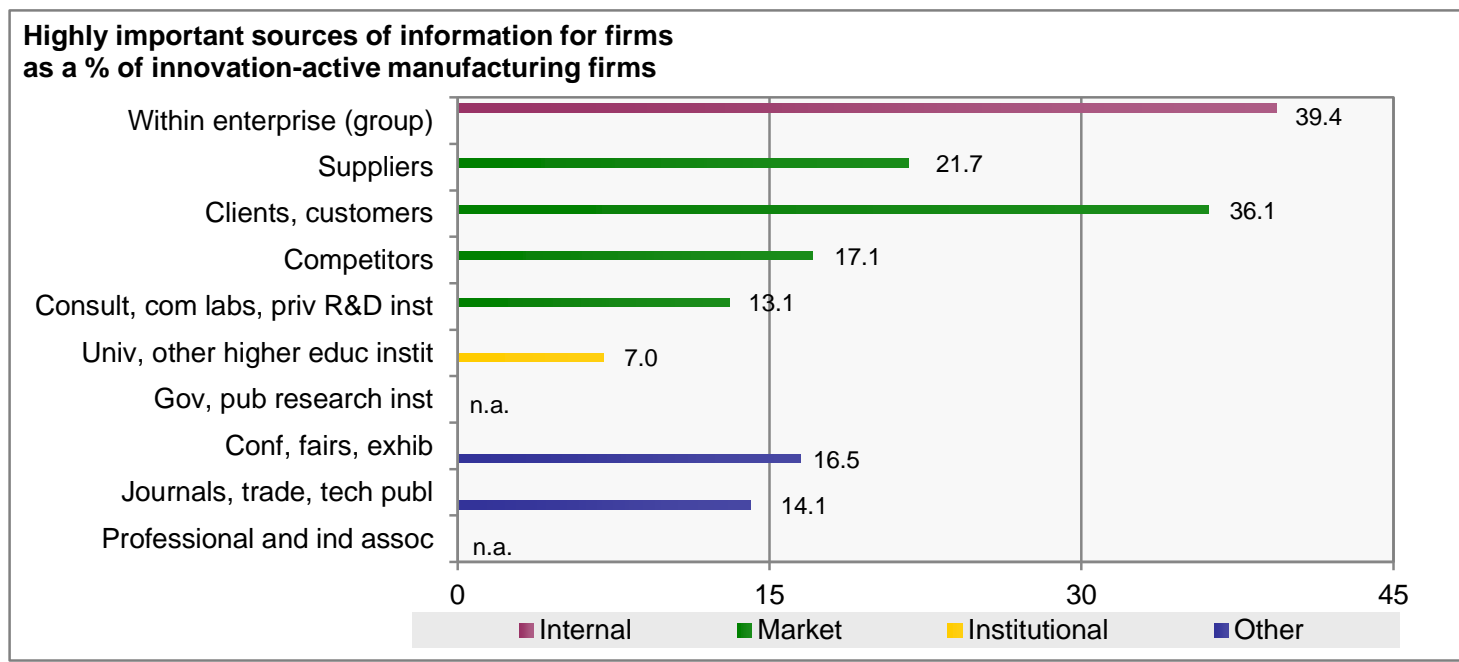

Notes: Data cover organizational and marketing innovators and exclude firms with abandoned or ongoing activities.

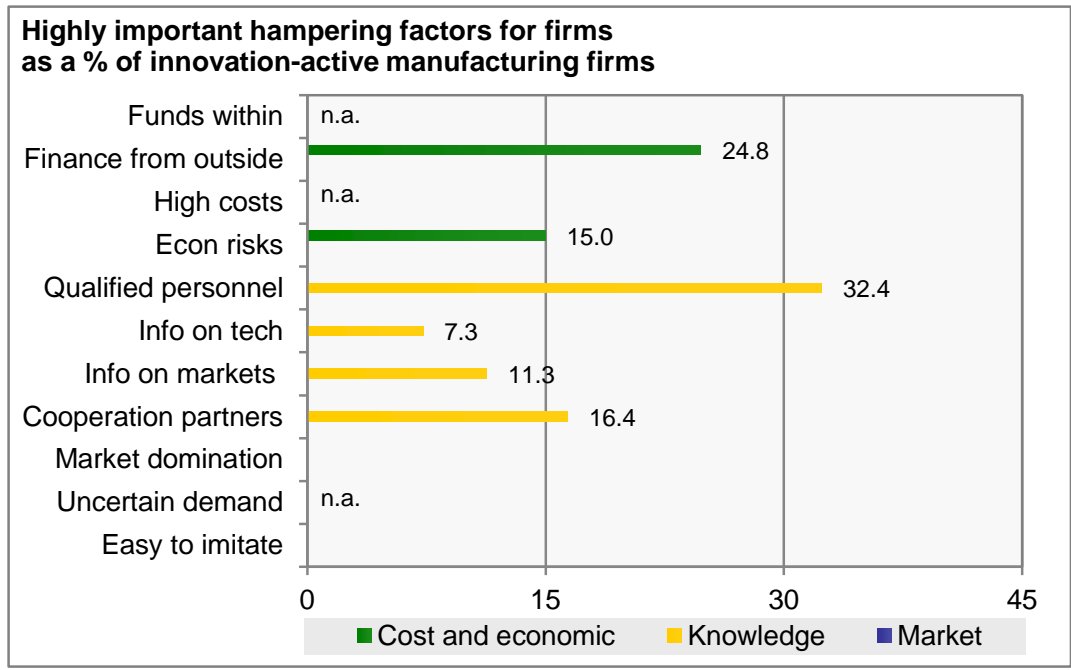

Notes: Data cover organizational and marketing innovators and exclude firms with abandoned or ongoing activities.

General notes: Based on a three-year observation period. For more specifications please consult the full report. 